\title{
Revitalization of Ancient Institutions: \\ The 1394 Governance Code for the Joseon Dynasty of Korea by Jeong Do-jeon
}

\author{
By \\ Kyongran Chong
}

\begin{abstract}
A thesis
submitted to the Victoria University of Wellington in fulfilment of the requirements for the degree of

Master of Arts in the School of Languages and Cultures
\end{abstract}

Victoria University of Wellington (2018) 


\begin{abstract}
The Code of Governance for the Joseon Dynasty written by Jeong Do-jeon in 1394 was the first legal document written in justification of a new Korean dynasty. The eminent Korean historian Han Young-woo has credited the political scheme formulated in the Code for promoting democratic ideas of power separation. This study argues that the Code cannot be considered as an attempt to introduce a new power structure in this way, as it was primarily concerned with revitalizing idealized Confucian institutions mobilized by the ideological force of weixin 維新 (revitalization) of guzhi 古制 (ancient institutions) and with creating a society modelled on Confucian values and hierarchical order laid out in the Chinese work, the Zhouli (Rites of Zhou). In his Code, Jeong used this system of government structure as the principle of ancient state institutions, to justify the position of the new Joseon throne, and he also adopted the legal format of the 1331 Yuan law book, Jingshi dadian, in which royal authority took precedence over that of the government. This study emphasizes not only Jeong Do-jeon's conservative adherence to the continuity of state institutions from the previous Goryeo dynasty (a replica of the Chinese Tang and Song systems), but also the priority he gave to the new Joseon monarch as a stabilizing force within the new dynasty, and argues that the Code was written to ensure continuity and priority, and cannot be considered as an attempt to introduce a new power structure.
\end{abstract}




\section{Acknowledgments}

I would like to thank my two supervisors. Dr. Limin Bai supported this study from the beginning. Her untiring advice on the structure and organization of the thesis is greatly appreciated. I am also grateful to Dr. Catherine Churchman for her encouragement and editorial expertise. I also wish to acknowledge the supportive environment of the administrative staff of the School of Languages and Cultures of Victoria University of Wellington. 


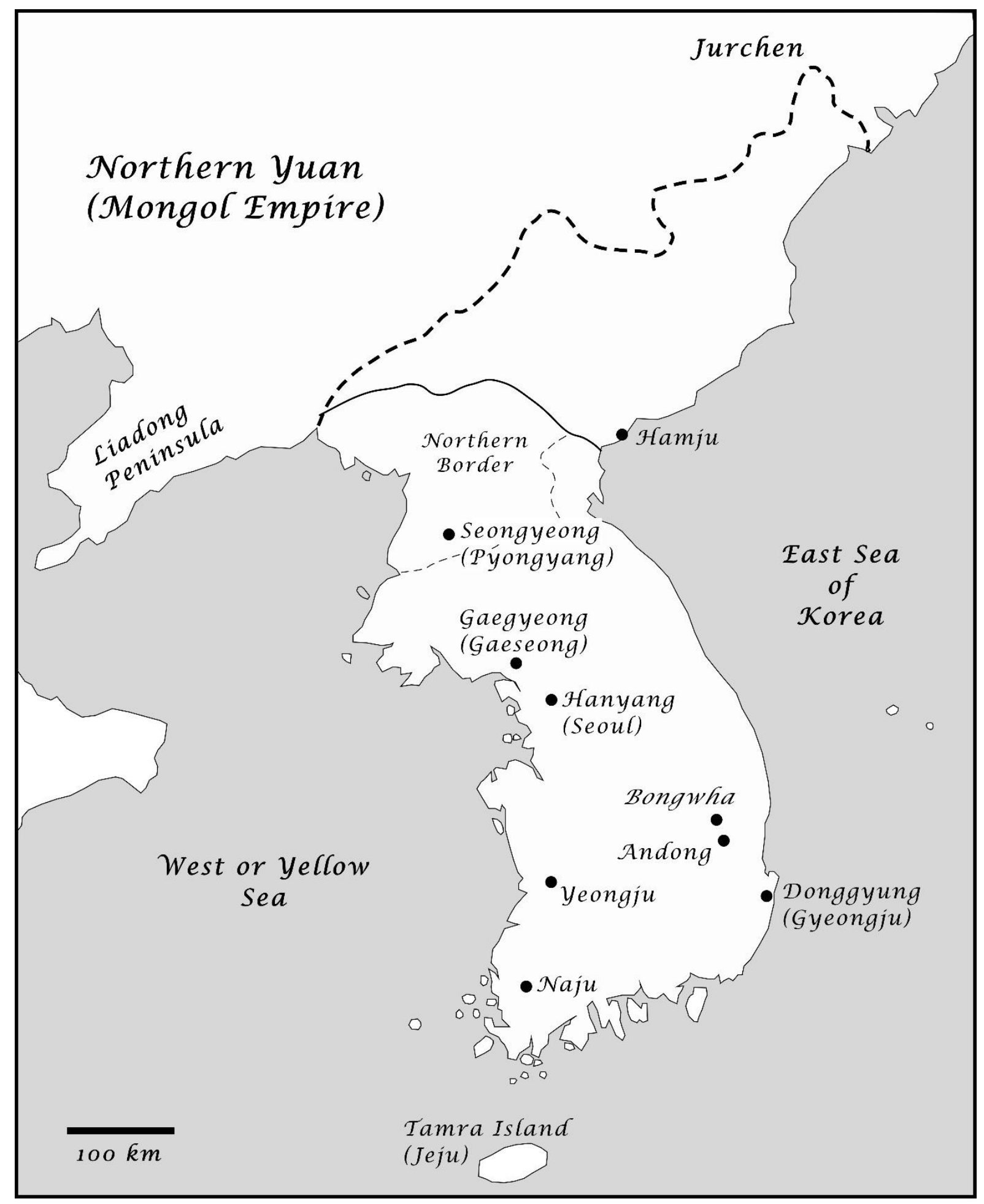

Map of fourteenth century Korea

\section{Dynastic Period of Korea}

Three Kingdoms Period: Goguryeo (BC 57- 660), Baekje (BC 18-668), Silla (BC 37-676), United Silla (676-918), Goryeo (918 - 1392), Joseon (1392 - 1910). 


\section{Contents}

Introduction . . . . . . . . . . . . . . . . . 1

Chapter 1. Life of Jeong Do-jeon . . . . . . . . . . . . . . . . . . 9

1-1. Historical Interpretations of Jeong Do-jeon . . . . . . . . . 9

1-2. Family Background . . . . . . . . . . . . . . . . . . . 12

1-3. Official Service . . . . . . . . . . . . . . . . . 18

Chapter 2. Weixin in Goryeo . . . . . . . . . . . . . . 23

2-1. Joseon 朝鮮: An Old 'New State Name' … . . . . . 23

2-2. Gija 箕子: Cult to Icon of a State . . . . . . . . . . . . . 27

2-3. Gija Joseon: A Territorial Little China . . . . . . . . . . . . 32

Chapter 3. Legitimacy of Joseon . . . . . . . . . . . . . . . . . . 39

3-1. Certainty of the Throne . . . . . . . . . . . . . . . . 39

3-2. Form Matters: The Adoption of the Jingshi Dadian . . . . . . . . 48

3-3. Kingship and Ministership . . . . . . . . . . . . . 57

Chapter 4. Revitalization of Civil Order . . . . . . . . . 64

4-1. The Zhouli 周禮: The Ancient Institutions, guzhi 古制 … ‥ 64

4-2. Law from the Tang; System from the Song . . . . . . . . . 70

4-3. Six Law Corpora: Net Ropes for Society . . . . . . . . . . . . 79

Conclusion . . . . . . . . . . . . . . . . . . 87

Bibliography 


\section{Notes:}

- Book titles and personal names which have Chinese characters are written respectively in English translation and Romanization, if needed, with the original characters in brackets.

- Romanization of Chinese words is presented in two ways: Chinese personal names are written in the pinyin system; Korean names in the Korean Romanization system established in 2000, e.g., Korean names written in Chinese like 鄭道傳, are Romanized as Jeong Do-jeon, which is phonetically closest to the reading of the characters or hanmun, not Zheng Daochuan in the pinyin system. The Korean Romanization system is provided for reference.

- English translation of source materials such as the Code of Governance for the Joseon Dynasty, the History of the Goryeo Dynasty and poetry and prose quoted in the thesis is the work of the author. However, quotes from Chinese classics are from modern translations most frequently consulted.

-Although the characters for reform '維新' are read as yushin in Korean, the author adheres to the Chinese pronunciation, weixin, so as to emphasis its enduring connotation in the history of East Asia.

Abbreviation of source materials

-. HMC: Hanguk Munjip Chonggan (Collections of Pre-modern Korean Literature)

-. JWS: Joseon Wangjo Sillok (Veritable Records of the Joseon Dynasty, Mt. Tebek Archive edition)

-. GS: Goryeosa (History of the Goryeo Dynasty)

-. GGS: Guyeok Goryeosa (History of the Goryeo Dynasty translated into Modern Korean, Gyeongin munhwasa Publisher, 2008)

-. SB: Haksunje 2016 edition of Sambongjip (Collected Works of Sambong, Jeong Do-jeon, compiled by Jeong Mun-hyeong in 1487)

-. Sambongjip: HMC edition of Sambongjip (Collected Works of Sambong, Jeong Do-jeon, revised and compiled by royal archive, Kyujanggak, in 1791) 


\section{Introduction}

This thesis is a study of the Joseon gyeonggukjeon 朝鮮經國典 (the Code of Governance for the Joseon Dynasty, hereafter referred to as the Code) of Korea (1392-1910) ${ }^{1}$ composed by Jeong Do-jeon (鄭道傳 1342-1398) in 1394 from the viewpoint that it was not an attempt to introduce a new governance system for a new dynasty, but to restore an old system for a new dynasty. Specifically, in practice the Code was designed to revitalize state institutions of the previous Goryeo dynasty that essentially replicated the penal laws of Tang and the system (culture) of Song China. The thesis also argues that the principle of dynastic rule Jeong Dojeon orchestrated in his Code was not one to establish power separation in government but to expand the authority of the king as head of state. The faithful copying of the Code from the structure of the Yuan law book, Jingshi dadian as an attempt to legitimize the throne by incorporation of traditional legitimacy into systematic legality, is central to my argument and the thesis interprets the Code as a political document rather than a legislative one, and moreover, argues that conventional debates over whether or not the Code should be regarded as a law book, have resulted in a distortion of the core meaning of Jeong's political design.

From the beginning of modern research into Jeong Do-jeon and his Code, the nature of his political thoughts has given rise to the conclusions that he was a law theorist, ${ }^{2}$ a NeoConfucian political theorist whose innovative thinking deserves as much attention as to Machiavelli in Europe ${ }^{3}$ a dynastic planner who influenced all sectors of Joseon society. ${ }^{4}$ Beneath the phenomena of evaluating Jeong's Code as the source material conveying the ideology of Joseon polity lies the distinction between two supposedly different systems, Goryeo 高麗 (918-1392) and Joseon 朝鮮 (1392-1910), which has been a dominant premise in modern studies and thus predetermined conclusions. Thus, there has been little investigation regarding the perspective of continuity of state institutions intended in the Code, and this is therefore one of the main themes of this thesis. Among the studies of Jeong Do-jeon and the Code of Governance, the works of the Korean historian, Han Young-woo, have occupied a

\footnotetext{
${ }^{1}$ Hereafter referred to simply as the Code.

${ }^{2}$ Park, Hong kyu. (2012). Jeong do-jeon sasanggwa hyeondae hanguk jeongchi (The political thought of Jeong Do-jeon and Modern Korean Politics), Keimyung Korean Studies Journal, 47, 127-156.

${ }^{3}$ Jung, Geung Sik (2016). Chosunkyeonggukcheon and the organization of the legal system in the early Chosun Dynasty, Seoul Law Journal, 56,

${ }^{4}$ Han, Young-woo. (1999). Wangjo-ui seolgyeja jeongdojeon (Dynastic Architect; Jeong Do-jeon), Seoul: Jisiksaneopsa.
} 
dominant position in academic debates. It is clear that Han's interpretation of the political thoughts of Jeong Do-jeon is largely a revision of the first generation of Japanese scholars in the modern discipline of humanities in the 1920s. His insistence on the democratic scheme of the Code has extended to studies in which Jeong Do-jeon has been portrayed as a 'radical reformist' and the 'dynastic architect' whose work marked the end of medieval Goryeo society, instigating an era of rule of law. In objecting to this characterization of Jeong Do-jeon, the main argument of this study will be introduced.

First, Han has suggested that the dynastic rule designed by Jeong Do-jeon was a constitutional monarchy in which the ruler could not practice arbitrary power but should follow the principle of 'rule of law' beopchi 法治 (chi. fazhi). The weakness in Han's interpretation of the political ideas of the Code is that he seems to have worked backwards from the dynastic change as a historical event that brought to Korean society a central bureaucracy with more civilized institutions. This is related with the connotation of the term 'reform', a rendition of gehyeok 開革 (chi. kaige) in Korean-Chinese usage, that resonates with the intellectual attempt since the sixteenth century in Korea to bring about institutional changes for a better organization of government affairs. ${ }^{5}$ If it is accepted that the mechanism of power separation in government is destined to be achieved through reform, then, it should meet the premise that the new Joseon dynasty was founded in order to bring an end to the exploitative rule of Goryeo monarchs. Moreover, in practice the norm of 'rule of law', i.e., human law, not the universal law, dao 道, is supposed to impose restrictions on the behavior of the ruler as the supreme authority. Consequently, Han's claim that Jeong Do-jeon intended to organize a power structure with a powerful prime minister at the top of the bureaucratic pyramid has mistakenly led to the claim that the throne was to remain only as a symbolic authority.

Jeong Do-jeon certainly advocated the role of the prime minister as regulator in the bureaucracy. Moreover, he established the ministership as a position that seems to have required higher moral standards than those needed for the ruler, so that the ruler could obtain help to rectify any possible moral failure of his own to practice governance based on benevolence. In many ways, Han Young-woo's understanding of Jeong's Code in terms of power separation reflects the argument of Wood (1999), who interpreted the political thoughts

\footnotetext{
${ }^{5}$ Palais, J. (1980). Han Yŏng-u's Studies of Early Chosŏn Intellectual History. The Journal of Korean Studies, 2 , 199-224.
} 
of neo-Confucians of the Song dynasty who had re-examined the conventional belief in the obedience to the ruler within the framework of authority and power. ${ }^{6}$ Wood articulated the metaphysical ideas of Song Confucians who had provided a standard of justice for historical events from the perspective of Confucius' compilation of the Chun qiu (the Spring and Autumn Annals) in attempt to seek the ground of the authority of the emperor. Their approaches were, Wood formulated, a way to prevent arbitrary rule of the ruler, which can be conceived as an informal institution of checks and balances of power. The weakness of Han's interpretation does not arise from a lack of understanding of hagiography, but from an obsession with the emphasis on moral politics. With no question of why or how, the typical strains in Confucian hagiography such as the principles of 'people as foundation' minbon 民本 (chi. minben) and 'governance by benevolence' injeong 仁政 (chi. renzheng) are most considered as the primary values in governance of the Code. Although the establishment of censors and remonstrance officials for '[free] path of speech' was credited for an evidence of institutional restrictions on the decisions of the ruler in the study of Han Young-woo, they were not new to the Joseon but were traditional of dynastic rule that survived a lengthy of time in East Asia. James Palais, who has provided a detailed review of Han's ideas, is helpful to better understand the nature of Joseon bureaucracy: he suggests that the bureaucracy was an organic mechanism in which kingship and ministership continuously interacted in order to maintain the central bureaucratic system in favour of their mutual political interests. ${ }^{7}$

A second problem in Han Young-woo's search for innovation in the Code is the ignorance of the fact in argument that the political thought of Jeong Do-jeon was loyal to Confucian tradition, no less a conservative adherent to the traditional principle of governance than any of his compatriots were. Investigation of Jeong's service to the king as a classic ritualist in the section of his family background and scholarship provides a different perspective of the codifier, challenging the way he has been portrayed as 'reformative theorist'. The reason for advocacy of the restoration of the Tang and Song systems of the Code, therefore, is viewed from a perspective of Confucian literati class confident in the moral capacity as the only group to be partners in governance with the ruler. Their power increased if the position of kingship was ensured. The state of infirmity of Goryeo kingship, fragile in the face of military and aristocratic power, will be discussed in relation to my argument of the Jeong Do-jeon's main

\footnotetext{
${ }^{6}$ Wood, A. (1999). Limits to Autocracy: From Sung Neo-Confucianism to a Doctrine of Political Rights, Honolulu: University of Hawaii Press.

${ }^{7}$ Palais (1995). A Search for Korean Uniqueness. Harvard Journal of Asiatic Studies, 55 (2), 409-425
} 
priority of in his composition of the Code - justification of the throne.

Third, when 'reform' is used about institutional changes one supposes that new factors were added or invented for more efficiency, and moreover, in a more appropriate way to cope with social change. Although Han Young-woo did not specifically determine the ingredients of reform that he believed Jeong Do-jeon had employed, it is not unreasonable to conclude that his idea that Jeong's thoughts were reformative appears to be related with constitutional monarchy or constitutionalism. This study does not deny the innovative characteristics of Jeong's political ideas but takes a different route, arguing that while the connotation of 'reform' employed by Han Young-woo (meaning a change to a state different from one that existed before). In this study 're-form' is interpreted as a rendition of weixin 維新, meaning 'revitalization [of the law and culture of sage kings and emperors]'. Then, what can be the destination of the propaganda of weixin? It was a replica of the penal law of the Tang and the government system of the Song, Chinese systems that were believed to have realized the governance principle of the Rites of Zhou. Then, can Jeong's design be said to be new in the political ideas he adopted for governance principle? It was not the introduction of radically new factors to a given set of circumstances. However, as often observed in history, change is often the consequence of a shift of emphasis and adjustment of an old phrase in a different arrangement. The way that Jeong Do-jeon embedded the ritualism into legal institution in the Code has shown such a shift of the components of tradition that has not been much noticed in modern literature.

This thesis also provides another perspective of viewing the Code, not just from the viewpoint of legislation but from a combination of informal cultural norms and legal institutions. As the study of the Code has recently been taken up within the domain of Korean legal studies, it has largely been examined only in relationship to later Joseon codes in terms of the six corpora system which makes up the archaic format of law books of Joseon Korea. These studies are similar to those of early Japanese legal experts who concentrated on three main issues: 1) the Code's bibliographical relevance with other documents and law books; 2) the status of the Code in the legal study of Korea; 3) the political thoughts expressed in the Code. Although these issues contributed to a useful expansion of our knowledge of the Code, they have also narrowed study of the Code to the confines of legal studies. This trend has unnecessarily caused a lengthy debate about whether Jeong's Code is in fact part of the legal history of Korea. As mentioned above, Jeong's faithful copy of the Yuan law book, Jingshi 
dadian, is essential to the idea advanced in this thesis that the dual structure of the Yuan code, and more importantly, the precedence of matter of the ruler to administration is interpreted as a representation of the hierarchical order of the power structure: the choice of the format itself was an attempt to legitimize the new Joseon throne as well as the position and role of the prime ministership. This is the most reformative aspect of Jeong Do-jeon's political scheme. It was a result of Jeong's habitual adherence to Chinese civil order and what he achieved was the realization of a Confucian source of legitimacy according to ritual propriety $l i$ 禮, of a new power, organized into a legal format, $f a$ 法.

Before describing the research framework of the thesis, some speculation on the interpretation of historical events should be mentioned. It cannot be denied or ignored that certain aspects of historical events attract a researcher's interest because historians may seek an answer to the past from the time in which they live. The 1970s marked the beginning of Han Young-woo's interest in Jeong Do-jeon and, as he admitted, in the societal and political environment of that time Professor Han started asking questions about the nature of democracy. President Park Chung Hee (1917-1979) who seized power in the 1968 military coup succeeded in 1972 to instigate a constitutional change that allowed for his permanent presidency by proclamation of the Weixin (Yushin in Korean pronunciation) Constitution. This motivated Han, then a history professor at Seoul National University, to delve into the political thoughts of Jeong Do-jeon, not as a source of Confucian despotism, but to uncover evidence of democratic principles. My interest in this study has come from a similar motivation about the function of the democratic system in modern Korea during the term of the former president Park Geun-hye (2014-2017), the daughter of late Park Chung Hee, and who could not complete her term in office because in March 2017 the Constitutional Court approved her impeachment that had been called for by the National Assembly in December 2016. It was the anger and half a year of candlelight rallies by Korean citizens against the abuse of constitutional power by individuals personally close to Park Geun-hye that led the national representatives to vote against her presidency. Joining the rally, personal curiosity not just the abuse of the presidential position but also a paralysed checks and balance system, led the author to read about the dynastic rule of Joseon through Han Young-woo's writing. As long as Han's study of Jeong Do-jeon inspires many, including the author, to make their own journey for answers about their own time, his intellectual endeavour has been justified. 
The imbedding of Confucianism into the legal institution of the Code by investigating the administration structure of the Rites of Zhou transformed into the principles of governance forms a central part of this thesis. It will be emphasized that the main thrust of the Code was not to devise a new institution in which the power of the ruler should be checked and balanced and he remain as symbolic authority, but to increase the power of the throne at the top of a Confucian hierarchy. Metaphysical aspects of neo-Confucian thinking are limited to the discussion of the background of the Zhouli. The following provides the framework of the thesis.

Three major elements support the main argument stated above. First, the concept of weixin is implemental as a thread connecting others. It is utilized as a vehicle of ideological movement to realize the Confucian statecraft of Jeong Do-jeon. The explanation of how a traditional rhetoric of reform, weixin 維新, has been reinterpreted in terms of neo-Confucian perspectives and led to the dynastic change is a key to understanding the nature of Jeong's governance code. Indeed, the concept of weixin is not homogeneous from its usage in modern interpretations but is varied with several renditions such as 'revitalization', 'reform' or 'revolution'. All of these rendered translations will be employed in more or less different contexts to allow each to suit the argument. The term 'revitalization', for example, is appropriate in a sense that it was to revive the ideal in practice; 'reform' is also valid in the case that institutional changes were expected to be conducted; in the propaganda of reviving kingly governance, wangdo jeongchi 王道政治 (chi. wangdao zhengzhi), that advocators insisted had been denigrated in their times, weixin was also instructive to drive dynastic change.

In a Confucian cultural context, weixin has frequently been a force at the centre of political crisis, yielding institutional changes to societies in East Asia in the second half of the nineteenth century. Some historical examples are helpful for understanding the intensity and directedness of the weixin rhetoric. The 1868 Meiji Restoration in $\mathrm{Japan}^{8}$ and the 1898 Hundred Days Reform in Qing China show similarities in their reaction against the challenge from the West. When Liang Qichao (1873-1929), an iconic modern Chinese intellectual, declared the 1896 reform, weixin (or ishin in Japanese) as a resolution to the cultural-political chaos faced by the Qing. What was required by weixin was the re-organization of Chinese legal

\footnotetext{
${ }^{8}$ There are numerous monographs on the Meiji Yishin. Among them, Beasley, W. (1972). The Meiji Restoration. Stanford: Stanford University Press.
} 
institutions..$^{9}$ Although Liang's weixin can be interpreted as a form of enlightened despotism, it was believed to be able to bring about progressive change and ensure national survival against the Western threat. ${ }^{10}$ The political movement and tendencies of Liang in the early period of his intellectual journey have similarities with those of Jeong Do-jeon. Both thought that weixin would lead to the reorganization of legal institutions in accord with the 'ancient institutions' guzhi 古制. To Jeong Do-jeon the 'revitalization' of state institutions was first to be conducted by the official procedure of adoption of the new state name of the new Joseon dynasty. I do not suggest that the development of weixin in court politics was ideologically consistent. The weixin discourse was not a static process but a dynamic surge involving changing strategies.

Then, what was employed to realise the principle of kingly governance in reality? Here, Confucian ritualism needs to be considered as another significant element. Weixin was not only the force to bring about change but also the vector moving towards a certain end of the 'ancient institutions'. If simplified, the theory and the practice; the end and the means. The world of the 'ancient institutions' was supposed to be realized through the Rites of Zhou, Zhouli, by which things that exist are given order. Jeong Do-jeon also used the official names from the work The Offices of the Zhou Dynasty (Zhouguan 周官), as the most powerful legitimate source of kingly governance. Therefore, my argument will be presented in a structure of guzhi the potentiality, weixin the mobility and the Zhouli the actus purus.

My thesis is composed of four chapters. The main discussion of Chapter One is the life and official service of Jeong Do-jeon. His and his father's service to King Gongmin (恭㤵王 r. 1351-1374) clarifies his cultural and political orientation. Chapter Two begins with the second article of the Jeong's Code, State Name. The state name of Joseon is closely linked with the ideal, the changing strategy of weixin, 'revitalization', and its advocators so I trace how it developed from the cultural rhetoric of Gija 箕子 (chi. Jizi) Joseon. In Chapter Three it is

\footnotetext{
${ }^{9}$ For different strategies and philosophical underpinnings of the two reforms and outcomes, see Shiping Hua. (2004). The Meiji Restoration (1868) and the Late Qing Reform (1898) Revisited: Strategies and Philosophies. East Asia, Berlin: Springer, 3-22.

${ }^{10}$ Following his tutor, Kang Yu-wei, Liang in his early political career had a strong belief in the revitalization of Confucian statecraft. After travelling to Japan and the United States he absorbed western ideas such as Darwinism and advocated for reform of Chinese institutions. For Liang's intellectual journey, see Hao, Chang (1971). Liang Ch 'i-ch' Intellectual Transition in China, 1890-1907, Harvard University Press: Zhang, J. (2014). The Tradition and Modern Transition of Chinese law, Berlin: Springer, 457; Mishra, Pankaj (2012). From ruins from Empire, London: Allen Lane, Penguin Books, 127-160. These references show how modern Chinese intellectuals such as Liang Qichao, Kang Yuwei and Sun Yat-sen, diagnosed and prescribed solutions for China crippled by disorder from its encounter with Western imperialism.
} 
argued that the priority of the early Joseon statesman, Jeong Do-jeon, was to bring certainty to the institution of kingship and royal succession. By investigating the first section of the Code, evidence that weak kingship was the cause of institutional crisis in the late Goryeo period will be examined. The dual structure and historical context of the compilation of the Yuan Code, Jingshi dadian, from which Jeong Do-jeon borrowed the entire structure for his Code, is explored regarding justification of the new throne. The matter of whether a powerful prime ministership was desired in the codification to restrict the ruler's power is also discussed with respect to the development of neo-Confucianism in Goryeo Korea in the last section of this chapter. Chapter 4 deals with the continuity of state institutions from those of the previous Goryeo dynasty. Adherence to the Zhouli system of the Code is discussed in the context of the attempt of Goryeo intellectuals to end institutional difficulties. The trend of continuous institutionalization towards the Tang and Song systems is discussed in terms of the restoration of civil order. In the Conclusion, it is again emphasized that Jeong's Code of Governance incorporated the traditional measure of legitimacy of authority and power into the legality of institutions by the political propaganda of weixin to organize state institutions according to the ideal Tang and Song systems. In this sense, it is expected that his ritualistic emphasis should be given more importance to interpret his political scheme of the Code not as a law maker but as a classicist. 


\section{CHAPTER ONE}

\section{LIFE OF JEONG DO-JEON}

Jeong Do-jeon (1342-1398) was one of most significant activators in the formative period of dynastic change from Goryeo to Joseon, which beginning in 1388. He amassed titles and positions responsible for reformative policies until the end of his life in 1398. At the same time, there is perhaps no persona who has been as controversial as Jeong Do-jeon in the premodern history records of Korea. At one end of the spectrum he has been described as a dynastic architect and at the other as a traitor.

\section{1-1. Historical Interpretations of Jeong Do-jeon}

Of the numerous descriptions of Jeong Do-jeon there are differences between early Joseon records and those of the late Joseon period and beyond. A recent paper by Kim Hak Yong analysed the official histories of Goryeo and Joseon and modern literature relating to Jeong Do-jeon in order establish his importance in terms of degree and stress centrality. If the degree of connectivity is high, then the stress centrality should be responsive to it, and this determines the credibility of the texts. These two criteria are used to determine the 'hub node' of the subject, Jeong Do-jeon, in the documents compared with his contemporaries and by which the connectivity and degree of importance that Jeong might have had should become apparent. The determined 'hub node' suggests that Jeong Do-jeon's positional importance in the network of his contemporary political partners and enemies was low. Kim concluded that the documents of Jeong Do-jeon in the early Joseon have a politically biased perspective. On the other hand, analysis of modern scholarship reveals that the degree and stress centrality of Jeong Do-jeon was higher, and therefore his importance in modern literature is confirmed. ${ }^{11}$

The primary official records of Jeong Do-jeon could not avoid being more or less biased by his contemporary chroniclers since he was executed on a charge of treason by a royal prince Yi Pang-won (r. 1400-1418) who later became the third Joseon king, Taejong. Jeong Do-jeon

\footnotetext{
${ }^{11}$ Kim, Hak Yong. (2015). Network giban joseonwangjo geongukgwajeong bunseok (Analysis of Foundation Procedure for the Chosun Dynasty based on Network). Journal of the Korea Contents Association, 582-591.
} 
was portrayed as an 'evil man'12 who 'deceived the ruler [Yi Seong-gye] with wicked scheme for his personal goals', ${ }^{13}$ and it was therefore proposed by officials that his name should be 'removed from the list of meritorious subjects'. ${ }^{14}$ However, it is not true to say that Jeong Dojeon and his scholarship were not recognised, and his descendants were not banned from entering official service. The only surviving son of Jeong Do-jeon, Jin 津, who after short period of being banned from entering official service served the position of the third-ranking minister, compiled and printed the compositions of his father entitled Sambongjip 三峰集. ${ }^{15}$ The first edition was followed by a supplementary second one by Jeong Mun-hyeong, greatgrandson of Jeong Do-jeon, who was also given royal permission to print Jeong Do-jeon's 'writing of historical exemplary rulers' ${ }^{16}$ during the reign of Seongjong (r. 1469-1494) in 1492.

As Gwon Geun (1351-1409) stated in the note, jeon (箋), to the first edition of Sambongjip, “[Jeong Do-jeon] has nothing left untouched regarding ritual propriety (禮 $l i$ ) and music (樂 yue), institution, yinyang 陰陽 and military science," ${ }^{17}$ the subjects of Jeong's works range from poetry, the military, the governance code, a compact version of the history of Goryeo rulers, and code of conduct for the monarch and civil officials to the saga of the Joseon founder, Yi Seong-gye. The third edition was published in 1791 during the reign of King Jeongjo with a critique against Buddhism along with newly discovered verses added after 1398. This last edition of Sambongjip is the one used in modern academic research. ${ }^{18}$ The composition of the Joseon gyeonggukjeon 朝鮮經國典 (The Governance Code for the Joseon Dynasty) was followed by two supplementary works, Gyeongje mungam 經濟文鑑 (Literary Mirror of Governance) and Gyeongje mungam byeoljp 經濟文鑑別集 (Supplementary Work of the Literary Mirror of Governance). These dealt with the role and morality of ministers and

\footnotetext{
12 Jeongjong sillok (record of the $13^{\text {th }}$ day of the third month of 1399). Joseon wangjo sillok (Mt. Taebaek archive edition of the Veritable Records of the Joseon Dynasty, hereafter referred to JWS) 3. 22:18b.

${ }^{13}$ Taejong sillok 7. JWS, 3, 7:4a

${ }^{14}$ Sejong sillok (second record of $22^{\text {nd }}$ of the first month of 1447). JWS 37, 115:4b

${ }^{15}$ Sejong sillok 35. JWS, $1,35: 21 \mathrm{a}$.

${ }^{16}$ Seongjong sillok 262. JWS, 40, 262:1b

${ }^{17}$ For the footnotes and prefaces of Jeong Do-jeon's works Gwon Geun (權近, 1352 1409), an eminent NeoConfucian scholar, should be noted as the most important contributor to the compilation of Sambongjip. For Gwon Geun's role and the bibliographical study of Sambongjip see Do Hyeon-chul (2013). Sambongjipgwa gwongeunui yeokhal (Characteristics of Sambong-jip and the Role of Gweon Geun). Minjok munhwa (Journal of Korean Classics), 40, 139-169; Oh Yong-Seob. (2011). Sambongjipui ganhenggwa pyeonseong (Study on the Contents and Publication of Sambongjib). Seojihak yonku (Studies of Bibliography), 229-253.

18 The collected works of Jeong Do-jeon have been compiled and published under two different titles; Samgbongjip (Collected Works of Sambong) and Sambong seonsaengjip (Collected Works of Master Sambong). As the latest (third) edition shared the same tilte with the first edition, it remains as it is, see Oh, Yong-seob. (2011).
} 
rulers from a peculiar Confucian perspective of history, illustrating good and the evil. These three works contain the concepts of governance and legal institutions, complimenting each other in the manner of a series. As seen from King Jeongjo's interest in Jeong Do-jeon's scholarship, Jeong Do-jeon's extensive collected works were acknowledged as being imbued with the elaborate Confucian spirit on which the new Joseon dynasty was based. Nevertheless, even in the eighteenth century it was still too early to restore Jeong's reputation regarding his service to the government because it conflicted with the official records of King Taejong's reign. It took 467 years for Jeong's tarnished name to be restored by the Queen Regent, Dowager Jo (1808-1890), during the reign of King Gojong. In 1865 during the reconstruction review of palace buildings destroyed by fire, Jeong Do-jeon was officially given an honorific title for his design and naming of the palaces, and his fame justly restored. ${ }^{19} \mathrm{He}$ was then honored as munheon 文憲 (worthy in document). This was the first and official royal acknowledgement of Jeong Do-jeon's contribution to the founding of the Joseon dynasty since his execution in 1398.

More recently Jeong Do-jeon has become fashionable not only in the academic realm but also in the popular cultural area. For example, a 1996 TV drama, "Tears of the Dragon", re-created Jeong's image as a brilliant scholar and politician who envisaged a society in which people were to be ruled by the law and the ruler's virtue. The most fascinating part of the drama concerns his last living minutes, which contradicted the official records stating that Jeong had begged for his life before his executioner. Instead, in the dramatization, Jeong is portrayed as a strong-minded warrior and philosopher going triumphantly to his death. Among a considerable number of dramatized films, academic papers and popular fiction novels since the 1990s, the book, Ingan Jeong Dojeon: sunsu yiseong eseo ye-eonjajeok sangsangnyeokeuroui yeojeong (The Man, Jeong Do-jeon: A Journey from Pure Reason to the Imagination of a Prophet, 2014), written by history professor, Moon Cheol-young, champions the 'idolization' of the statesman. ${ }^{20}$ Now, Jeong Do-jeon has been transformed into an icon of the grand designer of a dynasty and this phenomenon seems likely to continue. His essays about neighbouring peasant farmers of a remote village in the Naju area (see map) in southern Korea, and correspondence with his family, separated due to exile, have been taken as evidence of the true

\footnotetext{
${ }^{19}$ Gojong sillok 2. JWS, 6, 2:6a.

${ }^{20}$ Moon, Cheol-young. (2014). Ingan jeongdojeon: sunsu iseongeseo ye-eonjajeok sangsangnyeokeuroui yeojeong (The Man Jeong Do-jeon: A Journey from Pure Reason to the imagination of a Prophet). Seoul: Semunsa.
} 
nature of a real 'flesh and blood' person whose concern for the peasants led him to the radical ideal of equal land distribution.

\section{1-2. Family Background}

There are abundant records, public and private, of the life and career of Jeong Do-jeon: Goryeosa 高麗史 (the History of the Goryeo Dynasty), its abridged version, Goryeosa jeryo 高麗史節要, Joseon wangjo sillok 朝鮮王朝實錄 (Veritable Records of the Joseon Dynasty), and personal memoirs and anthologies of Jeong's tutor and those with whom he studied at the National Confucian Academy in the capital of Goryeo. ${ }^{21}$

Jeong Do-jeon was born the eldest son of Jeong Un-gyeong (鄭云敬 1305-1366) and a mother known only by her surname, U, from Yeongju, in 1342 and seems to have spent some years of his early childhood in the Goryeo capital. ${ }^{22} \mathrm{He}$ had two younger brothers, Do-jon (道存) and Do-bok (道復), and one sister whose name is not known. ${ }^{23}$ (see Fig.1). According to Jeong Do-jeon's biography of his father, ${ }^{24}$ his paternal family came from a minor clan in Bonghwa, near Yeongju, Gyeongsang Province (see map), where they had served for generations in the local government office as functionaries. There is plenty of evidence that his family, the Bonghwa Jeong clan was not regarded as gwonmun sejok 權門勢族 (literally meaning hereditary powerful families or clans) in terms of economic and social status ${ }^{25}$ in the

\footnotetext{
${ }^{21}$ The life and official service of Jeong Do-jeon is provided from entries in the sega (royal chronology), yeoljeon (biography) of the Goryeosa compiled in 1454; JWS (Veritable Records of the Joseon Dynasty) during the reign of the founder and the second ruler. The collected work of Yi Saek, Mogeunjip (Collected works of Mogeun, Yi Saek), and that of Yi Sung-in, Doeunjip (Collected works of Doeun, Yi Sung-in), also provide information on part of Jeong Do-jeon's life.

${ }^{22}$ For the date of Jeong's birth there are two opinions. One is based on an article in the Taejo Sillok (Veritable Records of Taejo) quoting Jeong's appeal to the court in 1397 that he could not make the journey to the Ming court because he was fifty-five years old, indicating that he was born in 1342. The other is that he was born in 1337, which takes into account the age of his peers who passed the government civil service examination in the same. The former birth date is generally accepted in academic research. Han Young-U wrote that for a person whose official service reached the level of a ministerial post, it is unusual not to have an official record of his birth date. Often called Sambong (three peaks), Jeong's pen-name is known to come from where he lived as a child, which is presumed to have been near Gaegyeong, the capital of Goryeo. (Han Young-woo,1999).

${ }^{23}$ Han, Young-woo. (1999). 15-22.

${ }^{24} S B$ 4: 1a.

${ }^{25}$ The term gwonmun sejok is combined with two concepts of inheritance and powerful families. See, Kim, Gwang-cheol. (1991). Goryeohugi sejokcheung yeon-gu (A Study of Hereditary Privileged Class of the late Goryeo). Pusan: Dong-A University Press.
} 
1350s. In his studies of social class and economic conditions of early Joseon society ${ }^{26}$ Han Young-woo has portrayed Jeong Do-jeon as a representative of the middle class whose small scale of ownership of land and three slaves was understood as his class badge. ${ }^{27}$ Based on such economic conditions, Jeong's aspiration for land reform in the late Goryeo has been adopted as a reason to consider him as a hero who developed class-consciousness and belief in the universal value of the 'well-being of the people'. However, Han's interpretation of Jeong's motivations are debatable and have attracted criticism by James Palais (1975) who analysed Jeong to be understood as driven by 'philosophic eclecticism'. In fact, it was more likely that Jeong's entitlement as candidate of the civil service examination that determined the class Jeong Do-jeon believed he belonged to.

Although Jeong Un-gyeong's great-grandfather had been given a nominal official title from the court for his service in the village community, this did not immediately bring about a rise in the social standing of the Jeong family, ${ }^{28}$ and they had to wait until the family produced a successful candidate for the civil service examination. The necessity of passing the state examination for social advancement was deeply related to the transformation of aristocracy into membership of central government as the state institutions were organized by the introduction of Chinese political system to Goryeo. In the early period of Goryeo it was important to create a cadre of personally loyal bureaucrats through which the dynasty tried to assure the allegiance of its officials. Among a number of special privileges granted to them, the protection system eumseo 蔭敍 (abbreviated as eum $)^{29}$ seems to have been the most appealing. This was the custom to allow offspring of high ranking officials above fifth grade to begin their social career without spending years studying Confucian classics. Thus, sons, grandsons and nephews of these high-ranking officials were advantaged by eum. Even for those who were willing to prepare for the civil examination an extra privilege was given: they were qualified to enter the Confucian Academy without passing the preliminary test. As application to the academy was limited to sons of incumbent officials, the system was also much favoured by yangban families in the capital. Consequently, the number of privileged candidates for government positions increased, and they poured into the capital from countryside.

\footnotetext{
${ }^{26}$ Han, Young-woo. (1973: 1976: 1983).

${ }^{27}$ Han Young-woo. (1991). Joseonui sahoigyeongje yeon-gu (A Study of Society and Economy of the Early Joseon Dynasty). Seoul: Eulyumunwhasa.

${ }^{28}$ For analysis of the status of the powerful Joseon descent group in the late Goryeo, see Duncan (2000; 99-116).

${ }^{29}$ The eum protection privilege was possible in a hereditary society in which sons of officials whose grades were over a certain level could advance to officialdom. Park, Hong-Gab. (2008). 혈연과 가문에 의한 등용, 문음제도 (Muneum (門蔭), the Appointment by Lineage and Birth). Issues in East-Asian Philosophy 18, 101-115.
} 


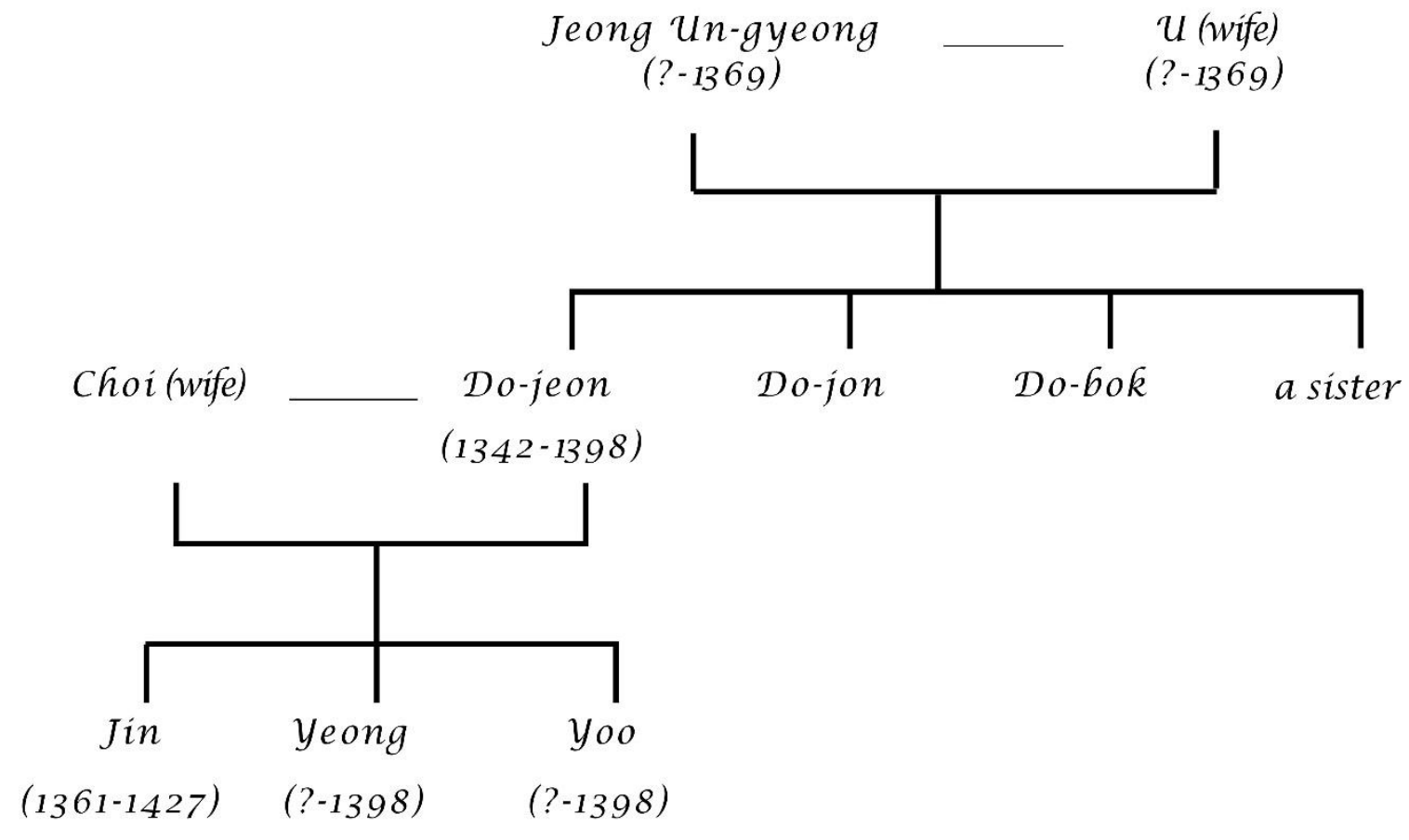

Fig.1. Family tree of Jeong Do-jeon

As Deuchler points out, the aristocratic ruling elites of Goryeo had an exclusive pool of marriage options which provided for their male offspring with a privileged way to maintain their social status: the 'protection' (eum 蔭). ${ }^{30}$ Given that informal political structure such as clan origin, patronage network, marriage ties and benefits could allow individuals to ascend the social ladder, the entry of the Jeong family into the 'inner circle' can be considered as exceptional. ${ }^{31}$ It was undoubtedly Do-jeon's father Un-gyeong's successful passing of the state civil examination that allowed the family moved to the capital, the centre of Goryeo politics. The Bonghwa Jeong clan therefore has the distinction of being the only clan among other

\footnotetext{
${ }^{30}$ The eum system makes it possible for the descendant of officials of fifth grade positions to begin their official career from low position without sitting the civil service examination. Park, Young-Un. (1982). Goreyo sidae-eu eumseoje-ui siljewa geu kineung (The Reality and Practice of the Eum System of Goryeo Period).The Journal of Korean History, 37, 28. The History of the Goryeo Dynasty (Goryeosa) in the section 'Monograph on Recruitment' states that in addition to the examination system and the eum privilege, men could advance into the regular bureaucracy from miscellaneous posts such as attendant posts, palace guards, astronomer or physician. This wide variety of recruitment mechanisms would seem to indicate the potential for substantial social mobility, but the evidence suggests that the mechanism of recruitments primarily served the interests of the dominant social groups, both central and local. Deuchler (1992). 84-86; Duncan (2010). 60-61.

${ }^{31}$ This is comparable to the situation that prevailed in the first 75 years of the Joseon dynasty, a period usually considered much more bureaucratic than the Goryeo, when $65 \%$ of top-ranking officials were examination graduates and $23 \%$ were eum appointees, indicating that passing the government service examination was important for official success in the early Goryeo period. See Duncan (2000). 62-63.
} 
powerful clans from which two members rose to above a third-ranking position during the reign of King Gongmin (r. 1352-1374). ${ }^{32}$

As a young intelligent student, Un-gyeong studied Chinese classics in Andong (see map), the nearest town to Yeongju, where he became acquainted with the eminent senior scholar-official Yi Gok. Their mentor relationship would continue into their sons' generation. Jeong Un-gyeong's knowledge of Chinese literature, which was widely recognized in his youth, enabled him to move to the capital for a better education in order to sit the civil service examination. In the capital, Jeong Un-gyeong spent several years studying with the patronage of his uncle An Bun (安奮) and successfully passed the highest level of the civil service examination in $1330 .{ }^{33} \mathrm{He}$ began his public service from a low civil position in charge of the collection and arrangement of archives and continued in official service for almost three decades ending his official life as the Minister of Justice (junior third-ranked) when he retired due to ill health to Bonghwa in 1363, dying three years later in 1366.

While serving King Chungmok (r. 1344-1348), Jeong Un-gyeong made a journey to the Yuan capital, Khanbaliq (present-day Beijing), accompanying seasonal envoys as a scribe, a job that required a good knowledge of letters and diplomatic affairs. This was in 1346 when Jeong Do-jeon was four years old. There are two records of Jeong Un-gyeong in the official History of Goryeo, Goryeosa. They portrayed him as a royal servant to King Gongmin on behalf of his reform of government. The section of the biography of 'good officials', yangni 良吏 in Goryeosa, provides details of Jeong Un-gyeong's official career which appears to have been a model of commitment to correcting corrupt local offices and providing proper judicial

\footnotetext{
32 Deuchler (1992). 92.

${ }^{33}$ It is not certain that Un-gyeong was entitled to be a candidate for the civil service examinations in Goryeo because the titles given to his father and grandfather in the Jeong family's genealogy were for their actual official service or honorary for local functionaries: that any family member in four generations to be an official of a high rank in central government and no family member from a low class. Here we need to examine Un-gyeong's maternal line, another important factor of the social standing of an individual. Un-gyeong's maternal line is the An family from Sunheung. One's maternal line was as important as the paternal one for social status during the Goryeo period. An Bun, Un-gyeong's uncle, who had succeeded in passing the civil examination in 1307 and another family member, An Chuk, were successful candidates for the Yuan government service examination in 1324 and served the Goryeo government in high-ranked offices. This could have given the An family membership of the ruling class, the yangban. Un-gyeong's maternal family background and their support of An probably contributed to his successful education and his passing the civil service examination. Sambongjip 4:1a (HMC 5, 359b); Kim, Yong-Oak. (2004). Sambong jeongdojeonui geonguk cheolhak (Sambong Jeong Do-jeon's Thoughts in State Craft), Seoul: Tongnamu. 18.
} 
services. Goryeosa recorded that Jeong Un-gyeong was invited for a drink by King Gongmin for his service as an inspector of local offices since the time of King Chungmok. His service continued throughout the early reign of Gongmin and he was invited to the king's private chamber along with another inspector, Seo Ho (unknown dates of birth and death), who had also served for the Jeongchi dogam 整治都監, a provisional office to correct wrongful administration. ${ }^{34}$ Both men were rewarded for loyally fulfilling their duties under the threatening influence of powerful families and individuals, including Empress Qi's family. ${ }^{35}$ There is another historical record in Jeong Un-gyeong's biography as also having been involved in an institutional reform. As a civil official, Jeong Un-gyeong called for the yuksekjang 六色掌 (six sub-offices) of the Privy Council, additional supervisory directors for the six ministries to be abolished because they negated the role of the existing six ministries. Responding to Un-Gyeong's appeal, King Gongmin promoted him to a third-ranking position the following year. As we shall see, having been absent for a decade from domestic politics, Gongmin's priority was to obtain allies and legitimacy for his power as soon as he was enthroned and returned home country. Despite the lack of records of influence he exercised at court, Jeong Un-gyeong seemed to have belonged to a pro-Gongmin party, and to be supportive of reforms, and his proposal to abolish extra sub-offices in the council was a good excuse for the King to execute the policy so as to expand his power over executive ministries without an ad hoc filtering system through the Privy Council.

Compared with written records of Jeong Un-gyeong, much less is known about Jeong Do-jeon's mother. The scarcity of information about his maternal lineage underpins doubts about the controversial origin of his maternal line - a local scandal that his maternal

\footnotetext{
${ }^{34}$ The correction body of Land and People established in 1347 by order of the Yuan court had multi layers of objectives and interest groups. The establishment of this body has often been considered in terms of reformative officials against a powerful group illegally dominant with large social resources. But for more complex networks and purposes in which individual officials saw difficulties in institutional reform to fix the malfunctioning land holding system, see Lee, Jung-ran (2005). Jeonghidogam hwaldongeseo deureonan gasokui ge-in-gwa geu-ui hengdongbangsik (Individual and Clan Behavior as Seen through the Activities of the Chongch'i Tokam), Qin The Journal for the Studies of Korean History, 21, 297-331. For the objectives of similar correction bodies, see Shin, Eun-Jae. (2006), Wonjong, chungyeolwangde jeonminbyeonjeong sa-eopui seonggyeok (Characteristics of Jeonmin byeonjung project in the period of Kings Wongjong to Chungryeol). The Journal of Korean Medieval History 21, 73-110.

${ }^{35}$ According to the records, the jeongchi dogam was ordered to be established by the Yuan Empress Qi in order to correct wrongdoings of pro-Yuan 'individuals' but it was terminated just after just two months. The increasing antipathy against Yuan harboured by Goryeo officials and commoners reached a point which even the Yuan court could not leave unresolved, although it turned out to be a makeshift measure to appease local pressure. See the section of Jeong Un-gyeong in the "good officials", Bibliography 34 of The History of Goryeo
} 
grandmother was the daughter of a low class "non-proper-mother". ${ }^{36}$. One instance in Jeong Do-jeon's early official career forecast what he would continuously confront in his social life. It was after he passed a court examination waiting for an official document of his appointment to a local office. One of the supreme ministers, U Hyeon-bo (1333-1400) spread word that he had known the commoner origin of Jeong's great-grandmother and his three sons even refused to issue Jeong the officially sealed document. Indeed, the matter of the origin of his mother is still controversial in modern studies and differences in opinion seem to have arisen from misinterpretation of the Yuan's influence on the pre-existing marriage and kinship relations in Goryeo from the Confucian perspective of later chroniclers. ${ }^{37}$ This was a continuing problem for Jeong and was used as an excuse to impeach him in the politically turbulent time before dynastic change, ${ }^{38}$

Jeong Do-jeon was in his teenage years when Prince Wang Gi was enthroned in 1351 as the thirty-first ruler of Goryeo, King Gongmin, by Emperor Toghon Temürthe (posthumously titled Shundi), the last emperor of the Yuan dynasty. This was a period of disturbance when the Yuan court experienced factional division between the imperial family and the Yuan ruling elite, malfunctioning administration, natural disasters such as flooding and epidemics, and the growing power of an increasing number of warlords. ${ }^{39}$ Having spent his

\footnotetext{
${ }^{36}$ In the usual biography or tomb inscription of a person from a cultured family it was normal practice to provide basic information of the deceased's three paternal generations and maternal grandparents. But in Jeong Do-jeon's case only three generations of his paternal line are recorded. Kim, Nan-ok (2007). Yeomalseoncho jeongchibyeondonggwa betajeok gamunuisik-jeongdojeoneul jungsimeuro (The Political Changes and the Family Consciousness during the Transition from Goryeo Dynasty to Joseon Dynasty - Focused on the Case of Jeong Dojeon). Journal for the Studies of Korean History, 27, 243-274.

${ }^{37}$ It is recorded that Kim Jeon, a remote relative of U Hyeon-bo, married the wife of one of the slaves of the U family and had a daughter. She is known to be the grandmother of Jeong Do-jeon (Taejo Sillok, $1^{\text {st }}$ year of reign, August 1392). In the early Joseon period, Jeong Do-jeon succeeded to impeach and execute three of U's brothers so that the written judgement of his personality in Goryeosa is not reliable. Han Young-U implies that from examination of the genealogies of the Jeong and Cha families, Jeong's grandmother could have been from another spouse of his grandfather which was not unacceptable under the Mongol marriage custom of polygamy. Han (1999). 4. It is presumed that there was a cultural collision between the Confucian social order and adopted Mongol custom, whether being of son of a 'proper mother' jeoksil 嫡室 or of a 'side mother' cheuksil 側室. Han (1999). 22.

${ }^{38}$ Goryeosa 高麗史 (The History of the Goryeo Dynasty) 117, yeoljeon (biography) of Kim Jin-yang, retrieved from kr_117_0010_0020_0020 (accessed 02/05/2018). Five censorate officials submitted a memorial calling for the punishment of Jeong Do-jeon. In their petition to King Gongyang they criticised Jeong saying that: "being originated from a humble class he planned a conspiracy to dethrone the king [the previous ruler, Chang] in order to conceal his origin..."

${ }^{39}$ Farmer (1995). 18-19. Dardess suggests that although in part the fall of Yuan can be attributed to the unfulfillment of Emperor Shundi's duties, failure to recognise the need for reducing the size of the bureaucracy,
} 
teenage years at the Mongol Yuan court in Khanbaliq, serving in the imperial guards suwei, King Gongmin was acutely aware of the increasing political and social problems of the Yuan. ${ }^{40}$ As he returned with his Mongol queen in the winter of 1351 to his father's country during this period of political instability, the twenty-four year-old king knew that he had to drive through strong reforms as early as possible. The rise and fall of Jeong Do-jeon's political career was to go parallel with that of King Gongmin.

\section{1-3. Official Service}

Jeong Do-jeon's official service was not continuous and, political counteractive measures to his career, such as exiles and impeachment, occurred in the last few weeks before dynastic change in 1392. Jeong's service to the Goryeo kings can be divided into three stages; first, the beginning of his service to King Gongmin from 1362 to 1366; a second round of service from 1370 to 1374 until the death of Gongmin; and last from joining the faction of General Yi Seong-gye in 1384 to his death in 1389. Before entering the bureaucratic world Jeong had lived by teaching village children in order to support his family, a wife and infant son. ${ }^{41}$ Then, with other successful candidates from the Confucian Academy, he was eligible to be recruited for vacancies in local government offices caused by the incursion of the Red Turbans into the capital, Gaegyeong. When his first official term ended, he returned to the capital to serve in a post in charge of archives producing texts for national sacrificial rituals. He was then promoted to the office dealing with the 'practice of the proper manual for royal and national occasions'. In 1366 he resigned to return to his hometown, Yeongju (see map). This was because of his father's death in January of that year, followed by his mother twelve months later, and he decided to perform his parents' funeral and burial memorial services for

selfish and corrupt behaviour of officials, can be added improper handling of calamitous, natural and economic events, by which the emperor lost his control over the administration. See Dardess. (1994). Shun-ti and the end of Yuan ruler in China. The Cambridge History of China edited by Herbert Franke and Denis Twitchett, 6, Alien Regimes and Border States, 561-586.

${ }^{40}$ For the reformative policies of Gongmin, see Min, Hyeon-gu. (1998). Jeongchigaroseo-ui gongminwang jewi jeonbangi-ui hengjeoke bo-i-neun gyeohyeok gunjuroseo-ui myeonmo (Gongmin as a Politician: Personality as Reform Ruler in his early Reign). The Journal of Asiatic Studies 41, 271-296; Shin, Eun-Jae (2010). Gongminwang jeukwicho jeonggukui donghyanggwa jeonmin byeonjeong (The Political Development in Early Period of King Gongmin's Reign and Jeonminbyeonjung Project). Journal of Korean Medieval History 29, 371400 .

${ }^{41}$ Jeong Do-jeon and his wife Lady Choi whose name is not known, had three sons, Jin, Yeong, Yoo. Two of them except the eldest were killed on the way to save their father when informed the incident of his father on the 26th day of Auguest in 1398 (see Fig.1). 
three years. His three-year funeral and burial service in accordance with Zhu Xi's ritual manual was later recognized by the king as exemplary filial practice. ${ }^{42}$ Jeong's early scholarship, therefore, was not particularly conspicuous but that of a typical Confucian functionary in a lower position. 'Concern over things while living in the countryside', one of six songs composed around that time, provides a picture of a Confucian scholar reading Chinese classics, living simply in the expectation of resuming official service in the future as soon as he finishes his duty as a filial son. ${ }^{43}$

In 1370, Jeong Do-jeon visited the capital to find the National Confucian Academy reorganized with rearrangement of the curriculum promoting Neo-Confucian study for administration and policy-designing. He was then given a position as an educator on the recommendation of those who had studied with him there. Under the guidance of Yi Saek (李 穑 1328-1396), son of Yi Gok (李穀 1298-1351), as Grand Minister of the Confucian Academy, Jeong Do-jeon lectured on the philosophy of the 'Four books and Five classics'. It was not long before his knowledge of Chinese literature and rituals helped him to be promoted to the Advisory of Rituals in 1371. Soon after this when the Goryeo realigned their investiture relationship with the Ming, Jeong Do-jeon was selected for the service of the national ritual at the royal shrine to memorialize the occasion in accordance with propriety and musical practice suitable for a vassal dynasty subordinate to the Ming. Pleased with his service, King Gongmin appointed him concurrently to positions in educational and ritual institutions. However, when the reign of King Gongmin came to a sudden end with his assassination in 1374, Jeong Dojeon and his colleagues found themselves facing a new political challenge from the dominance of royal relatives and their collaboration with the military generals in the council.

Jeong Do-jeon's second period of service to the King Gongmin ended with his personal and official break from central government until his encounter in 1384 with Yi Seong-gye, Chief Commander of North-East Region, but who had been out of central politics. On the death of King Gongmin, ${ }^{44}$ the power landscape of the court changed as suddenly as did Goryeo's diplomatic position between the Yuan and Ming. Yi In-im, a strong supporter for the succession

\footnotetext{
${ }^{42} \mathrm{After}$ almost two decades, Jo Jun in his 1388 memorial asked the second to last king of Goryeo for the regulations for the family rituals organized by Zhu Xi of the Song Dynasty. Goryeosa 114, yeoljeon 31, Jo Jun, retrived from kr_118r_0010_0010_0030, accessed 02/05/2018.

${ }^{43} S B$ 2:16b.

${ }^{44}$ Goryeosa 64, ji, 18. Retrieved from kr_064_0010_0010_0010_1310 (0205/2018).
} 
of Gongmin's son, later King U (r. 1374-1388), was quick to reinstitute the tribute relationship with the Northern Yuan which had been pushed into the northern part of China by the Ming. ${ }^{45}$ The change of hierarchical order in diplomacy brought strong resistance from civil officials who had been involved in Gongmin's reform policy and ten of those from the Confucian Academy including Jeong Do-jeon were sent into exile. In addition, Jeong was banned from entering the capital for six years until 1380.

Two collected works of Jeong's poetry and prose, Geumnam japje 錦南雜題 (miscellaneous essays of Geumnam) and Geumnam jabyeong 錦南雜詠 (Lyrics of Geumnam) were written during his period of exile in the rural area of Naju in southern Korea amongst farmers and commoners. Descriptions of those from the noble class wearing a scholar-robe with a cap living with low class people and having a humble attitude to the tillers-of-the-soil is rare so that examples were again referred to as evidence of the 'enlightenment of an intellectual' responsible for the people's well-being by Han Young-woo. ${ }^{46}$ Moreover, Moon Young-cheol has portrayed Jeong Do-jeon's life in heroic terms, as a case of a stereotyped life progression of a 'privileged person' passing through stages of suffering, self-awareness of mission, achievement and then tragic ending. For a Confucian student such as Jeong Do-jeon, remuneration through teaching and writing was virtually the only option for making a living, although this did not provide enough to support his family, a wife and now three sons that were separated from him. In correspondence with Jeong, his wife, Lady Choi, he lamented that she and the children suffered hunger and social isolation, ${ }^{47}$ and many of his poems, including 'Living in the countryside, chon-geo (村居)' express the solitude he felt being away from home. $^{48}$

In 1377 Jeong Do-jeon was pardoned from exile and allowed limited freedom to move but not to enter the capital. After four years of unstable living conditions in various places he returned to his hometown, opened a private learning chamber in which local young men came

\footnotetext{
${ }^{45} \mathrm{Yi}$ In-im, the supreme minister, controlled state affairs as the top-ranking official of the joint body of the State Councilors, jaesin and chusin, from the Secretariat-Chancellery and the Security Council. Kim, Dang-taek. (1997). Political Tensions over the Diplomatic issue with the Northern Yuan in 1375. Jindan hakbo 83, 21-41.

${ }^{46}$ Han Young-woo. (1999). 34

${ }^{47}$ Ibid. 35

48 "While living in the countryside, all [companionship] is broken; [I] can't see any visitors. Wilted leaves falling before the frost comes; chrysanthemum blossomed after rain. With books left in the room I treat myself to a drink I've found. Not only to try to forget the world; it's been long since the darkness in my mind's gone." Written in autumn of 1380, oeon yulsi 五言律詩, chongeo 村居, $S B$ 2: $20 \mathrm{~b}$.
} 
to learn reading and writing the Chinese classics, and it seemed there was little chance for Jeong to regain a position in officialdom. Seeking an alternative place to reside became critical due to hostility from local powerful families - his study was demolished twice. After two moves in 1383 Jeong visited the military unit under control of Yi Seong-gye in the North-East border region (see map). His encounter with the Commander-in-Chief of the North-East Region, marked the turning point in his life and moreover, the beginning of the end of the Goryeo dynasty. It is known that he visited army units led by Yi in the East-North-East region through Jeong Mong-ju who mediated a meeting between Jeong and the radical reformer Jo Jun. ${ }^{49}$ Coincidently, after his second meeting with Yi in 1384, Jeong was able to return to an official position - a literary one, as a fourth-rank official responsible for the writing of official ceremonial occasions, and the next year was promoted as Grand Minister of the Confucian Academy on the recommendation of Yi Seong-gye. Having served King Gongmin in his policy of military expansionism, Yi had earned great respect, but the regional limits of his influence pushed him to ingratiate himself with those in central government for mutual benefit. More specifically, what Yi needed most was those who could at least provide checks and balances in the decisions of the Privy Council by way of remonstrance. The fact that the court was dominated by Council members who were royal relatives based in the capital with their own military guards, explains this alliance between civil bureaucrats and the minority of the Council which had a regional military basis.

The third stage of Jeong Do-jeon's official career began in 1388 when Yi's military units turned around en route to the Liaodong Peninsula campaign, returned to the capital and staged a military coup marking a turning point in Goryeo politics. King U was deposed and then murdered one year later and his successor, U's son, Chang, then only nine years old, kept his throne for just two years before he suffered the same fate. During the momentous decade from 1388 to his death in 1398, Jeong Do-jeon played a key role at the heart of government: concurrently serving in important offices and positions, as the second highest decision maker in the Ministry of Finance, ${ }^{50}$ consulting the king over questions of state, as Joint Envoy for

\footnotetext{
${ }^{49}$ Jeong Mong-ju, who passed the civil service examination, also served as a military assistant of Yi Seong-gye during a military campaign in 1365 . He is also known to have introduced Jo Jun to Yi to whom Jo presented a copy of Daxue yanyi 大學衍義 by Zhen Dexiu. Jeong Mongju's association continued in the reign of King U in battles against Japanese pirates in the latter part of the 1370s. Kim, Dang-taek. (1998). Goryeo uwangde iseonggyewa jeongmongju, jeongdojeonui jeongchijeok gyeolhap (The Political Coalition of Yi Song-gye, Chong Mong-ju and Chong To-jon in Koryo King U's reign). Yeoksa hakbo (Korean Historical Review), 158, 31-62. ${ }^{50} \mathrm{JWS}, 2,4: 7 \mathrm{~b}$.
} 
Celebrating the Sacred Occasion of the Birthday [of a Chinese Emperor or Empress], and involved in communication with the Ming court defending the 'false accusation' against him. ${ }^{51}$ In 1391 he was promoted Grand Minister of the Confucian Academy and concurrently as the Minister of the Consultative Bureau. However, there was one last setback to overcome: he was denounced by a censor and again sent into exile and imprisoned. Threatened with execution, he was pardoned by the last Goryeo king, Gongyang, and returned to the capital during the final chaotic interval before the downfall of the Goryeo dynasty in the summer of $1392 .{ }^{52}$ There, he drafted the inaugural announcement of the founder of the new dynasty, Yi Seonggye, and according to protocol travelled to Beijing as third envoy to consolidate the sadae tribute relationship with the Ming and to obtain nominal approval of the new state name. Having started official career as a loyal subject of King Gongmin of the Goryeo dynasty as a ritualist, Jeong Do-jeon found a new role under a new master.

As seen so far, although having been associated with the founding of Joseon, Jeong Dojeon was judged extremely negatively by chroniclers of Joseon until the end of $19^{\text {th }}$ century. Over the past century readers have seen change in interpretations of the conservative Confucian and his contribution to institutional reform in Korea. Now, the pendulum has swung to the other extreme and Jeong Do-jeon is now portrayed in popular culture as well as in academic community as the institutional and ideological architect of Joseon dynasty whose intellectual journey paved the way to the Confucianized society of Korea. As more research and translation of his writings are undertaken, this trend of interpretation of Jeong Do-jeon appears to be increasing in popularity.

\footnotetext{
${ }^{51} \mathrm{JWS}, 3,11: 9 \mathrm{~b}$.

52 In 1392, Jeong Do-jeon was impeached for wrongful exercise of his authority on the charge that he had looked into a sealed royal edict, and once again was sent into exile. Han (1999). 49.
} 


\section{CHAPTER TWO}

\section{WEIXIN IN GORYEO}

The dynasty of Goryeo which had been founded by Wang Geon in 918 ended in 1392 in the capital, Gaegyeong, and the main priority of the succeeding political power was to establish new state institutions. The diplomatic process for the new political entity was so complex that it took nine months to achieve. The first two articles of Jeong Do-jeon's Code present the result of these international communications - justifying the new ruler and the new 'state name'. Interaction between the Ming and the new court of Joseon involved various rituals appropriate to the sadae tribute relationship and they also provide an understanding of how Goryeo Korea had been regarded by the Chinese and the Koreans themselves. On various documents, Korean historian Huh Tae-yong argued that there was a double task to achieve by adopting the name of 'Joseon'- both to reduce diplomatic tensions and to maintain the cultural and political norms of the past. ${ }^{53}$ In fact, Joseon was not the only candidate for the name of the new state, but the choice of this name was related to what kind of polity the new state was intended to be.

\section{2-1. Joseon 朝鮮: An Old 'New State Name'}

Fourteen days after the last Goryeo king, Gongyang, was dethroned, the new dynasty's founder, Yi Seong-gye, issued his first announcement to the Korean public. It says that, 'the state name should remain Goryeo and the 'law and ritual eujang beopje' 儀章法制 (chi. yizhang fazhi) be maintained as it has been'. ${ }^{54}$ Among the seventeen articles of this first announcement is the adoption of the Ming Code as the primary penal law. The status of the Great Ming Code, Da Minglu 大明律, which had been accepted by Goryeo since 1388 as the primary penal law, was thus reaffirmed. Above all, confirmation of the stability and justification of the new dynastic order took priority. To achieve this, it was critical for the new government to both preserve the sadae relationship with the Ming and ensure the seamless rule of law. Jeong Do-

\footnotetext{
${ }^{53}$ Another name for the new state was 'Hwaryeong (和寧)', the place where the founder of Joseon came from and where Yi Seong-gye had started the new dynasty (wangye 王業). Huh, Tae-Yong. (2015). Joseonwangjo-ui geongukgwa gukho munje (The Foundation of Joseon dynasty and Problem of Naming). Hanguk sahakbo (The Journal for the Studies of Korean History), 61, 160.

${ }^{54}$ Taejo sillok 1, JWS 1, 1:43a.
} 
jeon as one of early envoys to the Ming was deeply involved in the process.

The first envoy to the Ming was Jo Ban (趙胖 1341 1401), a Korean-Chinese official who conveyed the news of the dynastic change in Korea to the Ming court. Within a month, the Joseon government sent another envoy to reaffirm the hierarchical order between the two countries. Although the message brought back from the Ming court by the second envoy was full of condemnation for the usurpation of the previous dynasty, an act against Confucian morality, there was at least official recognition of the end of the Goryeo dynasty:

Not long after they had come to ask for an approval of the succession of the son of King Gongmin, they came again saying he was not Gongmin's son; and then not long after they had enthroned Wang Yo, they came again, saying Wang Yo was the legitimate offspring of Wang royal family. He was also murdered before long. It was none other than Yi [Seong-gye] who has been seeking to take power. I would not judge and let him do whatever he wants to do. But it should be ensured that he makes the people comfortable and does not stop trade and communication. ${ }^{55}$

Jeong Do-jeon was the third envoy to the Ming, taking sixty horses as a gift for the Hongwu Emperor in October 1392. It was not until the ninth of December 1392 when the Emperor approved 'Joseon' as the new state name for Korea, but there is no record who advanced the letter concerning the candidates for the state name. Given the time that Jeong Dojeon travelled to the Ming court as third envoy, it is reasonable to assume that he or someone in his entourage could have been the person that brought the news to Korea of the Ming's approval.

The Hongwu Emperor had had a favourable attitude to Goryeo because of king Gongmin who had resumed the sadae relationship and divorced himself from the Yuan as soon as Zhu Yuanzhang established the Ming dynasty in Nanjing in 1368. Until the collapse of Yuan power in 1388, the geopolitical situation in Northeast Asia was in turmoil due to uncertainty about each country's security. In the 1370s when the Yuan still retained power in Mongolia, they remained a potential threat to the stability of the Ming, and the Hongwu Emperor appreciated Goryeo's support. One record shows how concerned the Ming emperor was over the news that the Goryeo king had placed too much reliance on a Buddhist monk for running state affairs,

\footnotetext{
${ }^{55}$ Taejo sillok 2, JWS 1, 2:14b.
} 
and that he sent him Confucian classics advising him to cultivate Confucian virtues in order to be a better ruler. ${ }^{56}$ However, with the death of Gongmin on October 27, 1374 almost at the same time as envoys from the Ming to Goryeo were murdered under mysterious circumstances, tension between the two countries escalated. ${ }^{57}$ In addition, King U, Gongmin's young successor, was under the influence of his grandfather as the Supreme Minister and other senior members of the Council in charge of the military, and this meant that Goryeo had returned to the sadae relationship with the Northern Yuan. While threatening the Goryeo government, the Ming court did not halt their efforts to convince Goryeo to corporate with them. In 1377 the Hongwu Emperor released three hundred and fifty-eight Korean hostages in China and reduced the amount of tribute paid by Goryeo. ${ }^{58}$ Between the rising Ming power and the decaying but still influential Yuan power, Goryeo's only option was 'shuttle diplomacy', which although not fully satisfying both powers at least brought temporary peace. The ten year-long delay of the approval of investiture and posthumous title of King Gongmin and enthronement of his successor was an indication of this tension. The Veritable Records of the Joseon Dynasty, Joseon wangjo sillok only records a moderated response from the Hongwu Emperor during the reign of the founder of Joseon. The antagonism of the Emperor is well known from the August Ming Ancestral Instruction, Huang Ming zuxun 皇明祖訓, in which makes it clear that he harboured reservations about the dynastic change in Korea and also strongly criticized Goryeo as a country of "barbarians". Regarding the incidents of the abdication of four Goryeo kings and their murder, Hongwu Emperor left instructions for the next generation, saying that, “Goryeo, Yi In-in and his son Yi Seong-gye are now honoured. From Hongwu 6 (1374) until Hongwu 28 (1396) a total of four kings from the Wang clan were killed, so for the time being we treat them as barbarians." ${ }^{59}$ While Korean scholarship has portrayed the status of Goryeo

\footnotetext{
${ }^{56}$ Park, Won-Ho. (2005). Goryeowa juwonjangui chot gyeoseope gwanhan sogo (A short note on the first contact between Goryeo and Zhu Yuanzhang, Dongbuga Yeoksa Nonchong (Collected Articles of the Northeast Asian History), 189-222.

${ }^{57}$ Robinson, David M. (2017). Rethinking the Late Koryo in an International Context. Korean Studies, 41, 9091).

${ }^{58}$ Kim, Gyeong-nok. (2011). Yeomalseoncho hongmuje-ui goryeo, joseon insikgwa yoigyo gwangye (Relation between the Ming and Korea during the late Goryeo and early Joseon). Myeongcheongsa yeongu: The Journal of Ming-Qing Historical Studies, 15. 1-33.

${ }^{59}$ The translation is taken from that of Huangming zuxun (August Ming ancestral instruction) of Farmer (1995; 120). In his book, Zhu Yuanzhang and the Early Legislation the Ming (2000; 120), Farmer repeats the incorrect historical facts of the murders of Goryeo rulers from Hongwu 6 (1374) to Hongwu 28 (1395) before the foundation of the Joseon dynasty. He misinterprets the historical record of the bibliography of Yi Pang-won in the veritable records of the Ming, when he writes, 'it may refer to the succession struggles among Yi Song-gye's offspring', but what Zhu condemns is the killing of four Goryeo rulers, King Gongmin in 1374, King U and King Chang in 1389 and the last ruler King Gongyang in 1394. However, King Gongmin was not killed in the same way as his successors; he was murdered by one of his young boy companions.
} 
trapped between two powerful entities, the Ming and the Yuan in 1370s, David Robinson has provided a different view from the perspectives of the political interests of both dynasties. He asserts that the Yuan court and the Ming government were in competition seeking Goryeo's military support during the late fourteenth century. According to his analysis, Goryeo's acknowledgement of either of them in tribute relations meant legitimacy of their power and status in eastern Eurasia. ${ }^{60}$

When the letter of Ming approval arrived in December 1392, the new Joseon government of Korea replied within a month with an official letter of appreciation of Ming court approval. The name of Joseon, the letter stated, "had been used since the Gija period and now there was nothing honoured more than being accepted by the Hongwu emperor for the adoption of the name for the new royal order." 61

As the first documentation of the new dynasty, the second article of Jeong's Code, regarding the State Name, identified the institution of Joseon as follows:

There were three countries called Joseon in history; Dangun, Gija, and Wiman. ....Among all of the countries that flourished, Gija's [Joseon] was the one that had an acknowledgement from King $\mathrm{Wu}$ of the Zhou dynasty...Gija taught the great law of hongfan ${ }^{62}$ to King Wu and practiced Eight Prohibitions complimenting the hongfan. Since then culture prospered; customs were perfected. Now in taking such a beautiful state name from Gija the moral ruling of Gija also should be practiced again... ${ }^{63}$

Jeong ended the article ensuring institutional continuity from Old Joseon as the origin from which Confucian statecraft should be perfected. This is a major part of the examination of the legacy of Goryeo and its continuity with the Joseon dynasty. There are various communications between the Hongwu Emperor and King Gongmin in which the Hongwu Emperor denoted the country of Gongmin as Joseon, ${ }^{64}$ and his correspondence also described

\footnotetext{
${ }^{60}$ David Robinson (2017). 75-98.

${ }^{61}$ Huh, Tae-yong. (2015). 145-172.

${ }^{62}$ Hongfan 洪範 is an abstract term of the universal normative and also the first fascicle of the Book of Documents.

${ }^{63}$ Joseon gyeonggukjeon (The Code of the Governance for the Joseon Dynasty), Sambongjip 13, HMC 5, 414c. The English translation is by the author as noted in the introduction.

${ }^{64}$ The article of a day of the fifth month of the nineteenth reign year of King Gongmin, royal genealogy 42 in The History of the Goryeo 42, quoted in Huh (2015). 161.
} 
his small country since [old] Joseon had always received its investiture from China. ${ }^{65}$ Moreover, Gongmin's successor King U signified his dynasty as ‘our Joseon' located ‘between mountains and the sea' ${ }^{66}$ Then, who was Gija? How has he been portrayed as the messenger of law and culture from Chinese antiquity? Can the adoption of the name 'Joseon' (from Gija) be considered as a certain cultural and political orientation inherited from the past? Answers of these questions are related to the justification of the institutional changes that Jeong Do-jeon and other reformist Confucians wished to realize.

\section{2-2. Gija 箕子: Cult to Icon of a State}

The origin of the person named Gija has been controversial. The authenticity of Gija Joseon records appear in Chinese and Korean texts. Gija (箕子, Jizi) in most narratives and ancient records is known as a sage from the Shang dynasty (1100 BC) who was opposed to the tyrant Zhou and then moved to the East, founded Joseon and ruled according to law and culture ${ }^{67}$ Like ancient figures in early history it is a major problem for social scientists to validate whether the surviving records are compatible with information from archaeological investigation. Chinese records stated that the Zhou dynasty enfeoffed the Eastern region to Gija, but the questions of Gija's identity and the territory that he had supposedly ruled has become the subject of debate between Chinese and Korean historian in the late $20^{\text {th }}$ century. ${ }^{68}$ Written records of Gija do not match archaeological evidence, but this has been interpreted by some researchers as suggesting that Gija did exist, but much earlier than relevant records describe. Below, a brief sketch of the image of Gija in ancient Chinese texts is given followed by an explanation of how the collective cultural memory of Gija was integrated into the discourse of territorial polity and into state rituals.

\footnotetext{
${ }^{65}$ The article of a day of the second month of 23th reign year of King Gongmin, Royal genealogy 44 in Goryeosa: Ibid. 161.

${ }^{66}$ Ibid.

${ }^{67}$ Lee, You-pyo. (2017). Seoju (西周) chogi gija (箕子) ui joseon (朝鮮) chekbong (冊封) ganeungseong geomto: jehu (諸侯) chekbong yangsanguel jungsimeuro (Reconsidering “the Theory of Kija`s Migration to Joseon” in Early Western Zhou: Focusing on Kija's enfeoffment by King Wu). Inmunhak yeongu (The Journal of Humanities), 65-97. For archaeological evidence of Gija and his kingdom, based on excavated remains from the Shang and Xiao period in the Liao-xi area, see. Cho, Won-chin. (2010). Problems of Shang Zhou Dynasty's Bronzeware and the Kija-Joseon excavated from the Liao-xi Areas. Baeksan hakbo (The Journal of Baeksan), 101-127.

${ }^{68}$ Shin, Yong-ha. (2013). Gijajeoseonseol (箕子朝鮮說)ui sahoihakjeok geomjeunggwa beomgeum paljo (犯禁 8 條)ui silche (Sociological Scrutiny of Gija Joseon and the Fact about the Code of Eight Prohibitions). Gojoseondangukhak (The Journal of Gojiseon \& Dangun Studies), 29, 231-312.
} 
Various records of Gija appear in at least a dozen Chinese texts in which the image of Gija is both variable and composite; a wise man or a barbarian from the East, a slave or loyal minister. These disparate descriptions also appear in many stories relating what Gija did and when he moved to the East. These records and stories were eventually synthesized into a comprehensive description in Shiji by Sima Qian (presumably sometime between 145-86 BC). According to Oh Hyun-su, in Shiji the historian recorded that the first letter of Gi (chi. Ji, 箕) was the name of a country and $j a$ 子 (chi. $z i$,) the title for those from the noble class. As honourable titles were inherited by the offspring of olthe title holders, Gija, from the various texts, must have been the last such title-holder from the Shang dynasty. Oh also notes that the Shiji suoyin gives the name of Gija as Xuyu, a brother-in-law or Shuxiong of the Duke of Zhou of the Shang dynasty. Shang is the first Chinese dynasty recorded both in documents and archaeological evidence of the Bronze Age. ${ }^{69}$

The Gija discourses mentioning different details appeared between pre-Qin, up to the foundation of the Qin imperial dynasty in $221 \mathrm{BC}$, and pre-Han dynasty period (206 BC - 8 AD) of China. The book of the Han dynasty, Hanshu 漢書, known to have been written by Ban $\mathrm{Gu}(\mathrm{AD}$ 32 92) repeated the narrative of Gija as a messenger of law and culture to Joseon in the East in ancient times: "When the dao 道 [endowed for] the Yin dynasty was in decline, Gija moved to Joseon and taught them how to practice rites $(l i)$ and music (yue), and agriculture and sericulture. The people from Nangnang Joseon had the Eight Regulations to be enforced ..." ${ }^{70}$ Later, the image of Gija developed as a noble agent of Joseon enfeoffed by the Duke of Wu of the Zhou dynasty in the book, San Guo Zhi 三國志 (Annals of Three Kingdoms), compiled by Chen Shou. This is the same as recorded in Hou han shu 後漢書 (History of East Han) by Fan Ye (AD 398-445). Although there is no unified narrative among these accounts, the common details are that there had been a person, Gija who moved to the East where he started to govern the people by civilized law and culture.

To place Gija in the historical context of Korea a brief introduction to the pre-history period of Korea is needed. The historiography of Korea begins chronologically with three kingdoms of the Dangun Joseon 檀君朝鮮, Gija Joseon 箕子朝鮮 and Wiman Joseon 衛滿朝鮮

\footnotetext{
${ }^{69}$ Oh, Hyun-Su. (2016). Gijajeonseung (箕子傳承) ui hyeongseonggwajeong yeon-gu (A Study on the Forming Process of the Kija's Legend). Hanguk sahakbo (The Journal for the Studies of Korean History), 51-87. ${ }^{70}$ Ibid.
} 
as stated in the Code of Jeong Do-jeon. So as not to be confused with new Joseon, later historians have put the prefix 'go 古' meaning 'ancient' before these early Joseon names, in particular the first two. The belief that formulation of Gija Joseon brought into existence the first civilized political entity in Korean peninsula appeared with the compilation of the History of the Goryeo Dynasty, Goryeosa, in $1450,{ }^{71}$ and the cultural orientation towards Gija continued during the Joseon period. Among the three ancient Joseon kingdoms the legitimacy of Wiman Joseon has been questioned as not being legitimate because of the character of Wiman, known to be a non-righteous ruler as he usurped power from King Jun of Gija Joseon in the third century BC. When the Han dynasty unified China, according to the section of Joseon in Shi Ji, Han Gaozu enfeoffed Lu Wan as Marquis of Yan (燕), but as he found refuge in the territory of Han a political vacuum was caused among the Yuan. Then a man from the Yan Kingdom, Wiman, being the leader of a thousand remnants of the Yuan mobilized them in the region located between Han and old Joseon (Gojoseon) in 195 BC. He succeeded in earning the trust of the king of Gija Joseon and became commander of a large military force along the western border area. Then, when the Han dynasty began a military campaign against the Gija Joseon, Wiman, under the pretext of protecting the Gija Joseon court, declared himself the Joseon king. According to the Shi Ji, Wiman had come from the Yan dynasty but, according to Noh Tae-don other sources say he was a remnant of Gija Joseon in the Liaodong Peninsula area. $^{72}$ (see map). In brief, Wiman was defeated by the Han so his kingdom was short lived.

Analysing these ancient Chinese texts, Oh, Hyun-Su (2016), noted that the number of Gija records increased dramatically during the time of the pre-Han, suggesting that they had been manipulated in a way that later historians, who had been involved in the compilation of the history of Han dynasty, integrated the Gija Joseon into Chinese history in order to justify the forceful collapse of the Wiman kingdom. As Gija was the lord of Joseon enfeoffed by the Duke of Zhou, usurpation by anyone such as Wiman could not be legitimized. ${ }^{73}$ In the Gija and Wiman discourses in the Chinese texts there appears a certain development of 'Joseon narratives' regarding justification of the military conquest of Wiman Joseon by the Emperor

\footnotetext{
${ }^{71}$ Park, Dae-Jae (2016). Gijajoseongwa sojunghwa (Kija-Chosŏn and Little China). Hanguk sahakbo (The Journal for the Studies of Korean History), 8.

72 Noh, Tae-don. (2000). Wimanjoseonui jeongchigudo (The Political Structure of the Wiman Joseon). Dangungwa Gojoseonsa (Dangun and the History of the Old Joseon).

${ }^{73}$ In addition, Shin Yong-ha, adopting a social science methodology, compared the records of the pre-Qin dynasty with archaeological remains estimated to be a thousand years earlier than the written records, and suggested that the Gija discourse in the Pre-Han period was intentionally made up by contemporary Han Chinese historians. Shin, Yong-ha. (2013).
} 
Wudi of the Han dynasty. Gija Joseon discourse had shaped the cultural identity of people in what is now Korea well before modern scholarship in archaeology and the social sciences could study the pre-Qin period, especially in court debates by the ruling class.

Historical evidence of people who associated themselves with Gija Joseon was in fact based on a territorial polity. For instance, tomb scripts and records about those having lived in the Northern region of the Korean peninsula, i.e., part of Manchuria and Liaodong, shed light on this transition. For example, the inscription on the tombstone of a Goguryeo refugee in Zha Cheng (presumably Hunchun of Jilin, China), indicates that the Goguryeo had an ethnic and cultural identity as descendants of Gija. Another tombstone known to be for Gojil records a man from Liaodong Joseon. There is also a tombstone on which the person is described as a descendent of the Yin dynasty. ${ }^{74}$ According to these inscriptions, at least up to the sixth century, Joseon was another name for the Goguryeo kingdom and that this was widely accepted also revealed in Chinese texts. Among these is Wei Shu (the History of the Wei Dynasty), where along with information on the origin of the people in the northern part of Manchuria, the description of them provides geographical information on the location of the regional border of Goguryeo. According to the sources mentioned above, whoever Gija was in reality, the historically consistent person mentioned in texts or as an object of a cult, it cannot be denied that Gija became synonymous with the idea of the first civilized political entity of Korea.

In another record, the Goryeo section of the Jiu Tang Shu 舊唐書 (Old Tang History) $)^{75}$ states that the worship ritual of Gija had been practiced since the Goguryeo period (BC 100AD 668). The Xin Tang Shu 新唐書 (New Tang History) ${ }^{76}$ even provides the details of the shape or pattern of dishes used for the ritual. Then, why did Chinese historians consider the 7th century information of Goguryeo Korea as related to the Goryeo of their time? What they attributed with the name of Goryeo was one of the ancient kingdoms, Goguryeo; the founder of Goryeo following the United Silla Kingdom took the name but dropped the middle character 'gu' 句 in the sense that they culturally inherited the Goguryeo kingdom. Therefore, while the Gija narrative was relatively weak among the ruling class of Silla Koreans whose territorial

\footnotetext{
${ }^{74}$ Gwen, Eun Ju. (2014). Goguryeoyumin goheumdeok, gowonmang buja myojimyeong geomto. (Study of the Epitaphs of Go Heum-deok (高欽德) and Go Won-mang (高遠望), the displaced of Goguryeo (高句麗)). Daegu sahak (History Journal of Daegu University), 43-77: ibid. 31.

75 Jiu Tangshu 199 upper chapter cited in Park, Dae-Jae, (2016). 18.

${ }^{76}$ Xin Tangshu 220, cited in Park, Dae-Jae. (2016). 19.
} 
base was the Southern province, Goryeo Koreans whose territorial base was near and south of the capital of Goguryeo, Pyongyang, must have felt greater affinity with the local cult practice of the area. ${ }^{77}$ The Gija ritual and custom seemed to have attained its popularity, not as a Confucian service or sadae-related one, but as a cult, and that is why it was categorized as a miscellaneous ritual in the Ministry of Rites until the thirteenth century. ${ }^{78}$

There are various diplomatic documents in which the correspondents did not appear to have any problem in using Gija in reference to Goryeo. In the investiture letter of the founder of Goryeo, for instance, the ruler of the Huo Tang wrote that, "Since Jumong (朱蒙 BC 58-BC 19) $)^{79}$ opened a country, Gija has expanded the civilization of the country." ${ }^{80}$ The Khitans in a letter to the Goryeo king Seongjong (成宗 r. 981-997) in 996 complimented Goryeo as a country of the sage-king, Gija; the same notion was held by the Yuan and Ming as mentioned. ${ }^{81}$ The first emperor of the Song dynasty shared this traditional recognition of Goryeo in a 963 letter to King Gwangjong (925-975) of Goryeo where he mentions "following after the custom of Jumong's time; and law from Gija." In source material of the Northern Song, Goryeo is consistently recognized as a political entity with continuity in its law and custom from Goguryeo. ${ }^{82}$

As seen in the name of Goryeo, with one character missing from the previous Goguryeo, the founder, Wang Geon (877-943), had his cultural roots in the Goguryeo, not in the United Silla Kingdom. The status of Gija among Goryeo historians has been consistent as mentioned in Samguk Sagi (History of Three Kingdoms) by Kim Pu-sik (1075-1151): “Gija since he had

\footnotetext{
${ }^{77}$ Park, Yong-un. (2004). Gukho goguryeo, goryeo-e dehan ilgochal (On the Dynastic Names of Koryo 高麗 and Koguryo 高句麗). Dongbuga Yeoksa Nonchong (Journal of Stduies of North East Asia), 1, 29-49. Park suggested that the names of Guryeo, Goguryeo, and Goryeo have been inter-used for a political entity in Korea in Chinese and Korean records.

${ }^{78}$ Goryeosa 63, ji 17 (7 $7^{\text {th }}$ reign of Yejong in 1102): Lee, Kang-Hahn. (2010). 1325 gijasa jesajege (箕子祠 祭祀 再開) ui begyeongmit eumi (The nature and meaning of the Gija service resumption in 1325), Han'guk Munhwa: Korean culture 50, 3-26.

${ }^{79}$ Posthumously titled Dongmyeong seongwang, ruled Goguryeo, one of three kingdoms of Korea, between BC 37 and BC 19. Samguk sagi (The History of the Three Kingdoms) and Samgguk yusa (Memorabilia of the Three Kingdoms) are the oldest records of his reign. For the English translation, see The Koguryo Annals of the Samguk Sagi written by Kim Pusik, translated by Edward J. Shultz, The Academy of Korean Studies Press, 2011. Samguk Yusa: Legends and History of the Three Kingdoms of Ancient Korea, written by Ilyon and translated by Tae-Hung Ha and Grafton K. Mintz. Yonsei University Press, 1972.

${ }^{80}$ Goryeosa 2, sega 2; Park, Dae-Jae. (2016). 34.

${ }^{81}$ Yuanshi vol. 208, liezhuan 96, waiyi 1, gaoli: Ibid.

${ }^{82}$ Yi, Geun-myeong. (2010). Songwon side-ui goryeosajaryo 1 (Collected historical materials of the Song and Yuan related with Goryeo). Seoul: Sinseowon.
} 
been enfeoffed in the land of Hyeonto, and Nangnang, accomplished the dao of sage-kings." Then, how did the Gija discourse become integrated into the territorial-state ideology of Goryeo and then continue into the new Joseon? In Dongguk isanggukjip (Collected Works of Minister Yi of the East Country) by Yi Gyu-bo (1168-1241) and a memorial written by Kim Gu (1211 1278), Gija Joseon is connected with 'little China'. ${ }^{83}$ A more refined form of the Gija discourse appeared in the Jewang ungi 帝王韻紀 (Songs for Kings and Emperors) by Yi Seunghyu in 1287 where the territorial description of Goryeo hints at it being a nation-state. Yi Seung-hyu saw the Joseon [of Gija] as a polity that Goryeo had inherited and also referred to Goryeo as 'little China' (xiaohua 小華 or xiao zhonghua, 小中華). ${ }^{84} \mathrm{He}$ records that during the reign of King Munjong (r.1046-1083) Goryeo government sent a letter to the governor of the East Capital (old capital of the previous dynasty of Silla) saying "Goryeo inherited Gija [Gija Joseon] with the border along the Yalu River.” (see map).

\section{2-3. Gija Joseon: a Territorial Little China}

As mentioned, a political entity established by a person called Gija, had long been identified as a territorial state among those in the Northern province of the Korean peninsula (see map). The association of Gija with territorial statehood the state ritual would then develop in accordance with neo-Confucian statecraft as well. The Goryeo rulers utilized weixin as a vector to accomplish the political interests they wanted through Gija Joseon rhetoric and the desires involved in it, in various ways. A combination of the king and neo-Confucians proved to be a powerful force by the beginning of the reign of Gongmin in 1352. A group of neoConfucian civil officials, including Jeong Do-jeon, were at the center of the new phase of power transition in China which would exert an immediate influence on Goryeo state institutions.

Knowledge of Chinese classics and literary scholarship was indispensable in government administration since their introduction into Korea following the three kingdoms period (around from BC 4 to AD 6). Although Goryeo had been founded on Buddhist ideology in 918, the legal institutions of government were modelled on those of Tang (618-907) and Song China (960-1279). As the civil service examination system was transplanted in 958 in Goryeo, talented students educated in the Confucian classics, as Choi Seung-no (917-989)

\footnotetext{
${ }^{83}$ Ibid. 34.

84 Ibid. 42.
} 
clarified, were employed for the service to the king, while Buddhism remained as a private religious activity. ${ }^{85} \mathrm{~A}$ more sophisticated form of development of Confucianism as moral politics in Goryeo can be shown in the records of encounters of Goryeo envoys with Song Chinese correspondence.

There are many source materials in which Goryeo elites who travelled to China for diplomatic purposes introduced themselves as those from 'Little China'. ${ }^{86}$ During the reign of King Munjong of Goryeo (r. 1047-1082) Goryeo elites called themselves 'Little China' in diplomatic letters to the Northern Song. This was when the institutionalization of Goryeo had reached a certain degree of stabilization with roles and specialization of government offices in the 'civil-norm'. Interestingly, Song minister Wang Anshi's 'new policy' was adopted by Goryeo kings such as Sukjong (1096-1105) and Yejong (1106-1122) in order to expand the authority of the throne and strengthen the military for national defence against neighboring dynasties. ${ }^{87}$ Goryeo's military campaigning was conducted in combination with Gija ideology. In 1102 the shrine of Gija was built in Pyongyang, the old capital of the previous Goguryeo and now West Capital (Seogyeong). The reason for establishing a shrine of Gija is given in a memorial by the Ministry of Rites to the king stating that the performance of the rite for Gija had not been registered in the canon of rituals. ${ }^{88}$ Territorial statehood, accompanied the idea of 'Little China', in particular over the region that had been occupied by mixed ethnic groups including the former people of Goguryeo.

As Goryeo had been involved in territorial disputes with the Khitan Liao in the area of

\footnotetext{
${ }^{85}$ In Choi's essay of twenty-eight policies presented to the sixth ruler of Goryeo, King Seongjong (969-997), he warned of the evils of the Buddhists convention and the administrative abuses of local strongmen, both of which were endemic in the late Goryeo period. Lee, Nam Hee. (2013). Goryeoside-ui gwageojewa gonggongseong (公 共性) (Civil service examination of the Goryeo Dynasty and publicness). The Review of Korean and Asian Political Thoughts 12, 57-76.

${ }^{86}$ Park Dae-jae considered it Goryeo officials' self-consciousness. Park, Dae-jae (2016). Gijajoseongwa sojunghwa (Kija-Chosŏn and Little China). The Journal for the Studies of Korean History, 7-49. It was noticed that the 'Little China' rhetoric appeared in particular when they sensed the power transition in China in order to reposition their location in the international political order.

${ }^{87}$ Wang Anshi submitted in 1058 a memorial to Renzong of the Song dynasty - the famous Ten-Thousand Word Letter (Wanyanshu). In it he suggested political, financial and social reforms for a solution to the problems facing Song society. Although his reform policies were not adopted, Wang was appointed in 1067 by the successor of Renzong, Shenzong (r. 1067-1085), as Vice Grand Counsellor and was in charge of new polices. His reform policies cover a wide range of topics such as the imperial household budget, infrastructure of agriculture, labour, commerce, organization of the military. Wang's reform scheme and his commentary on Zhouli had a significant influence on the political thoughts and writings of Jeong Do-jeon. For Wang An-shi and his policies see Jiang Xijin, ed. Wenshizhe xuexi cidian Changchun: Jilin wenshi chubanshe, 1990, p.487.

${ }^{88}$ GS 63, ji 17, article during the seventh reign of King Sukjong in 1102: Lee, Kang Hahn. (2010). 5.
} 
Manchuria since the tenth century, the sadae relationship of Goryeo with Liao in the eleventh century seems to have been less enthusiastic than that towards Song China. ${ }^{89}$ Also, Liao's nomad tribal customs held no appeal to Goryeo Confucian elites who became self-conscious about being culturally superior to 'barbarian Khitans'. Although the Khitan Liao dynasty was later integrated into the history of China the History of the Goryeo Dynasty contains less information about Liao-related cultural influence or trade than it might have. The bilateral use of the era names of the Liao and Song dynasties in court chronicles can be considered as the distinct cultural and political orientation of Goryeo intellectuals. ${ }^{90}$ The cultural identity of 'Little China' was integrated into the state ritual of Gija, developed statehood and a neoConfucian perspective of a world order, to which we now turn.

It was the father of Prince Wang Gi, Wang Do (King Chungsuk r. 1313-1330, 13321339), of mixed Goryeo and Mongol descent, who integrated weixin discourse with the Gija memorial service during Yuan control of Korea in the fourteenth century. "When we correct our custom [according to those of the Gija era]" he announced, "the harmony of weixin will have begun." His policy of revitalization saw the Gija shrine repaired and the memorial service resumed. ${ }^{91}$ The expression of 'changing the custom and bringing the harmony of weixin' was rare in formal royal announcements during the Goryeo period; it had been used only when the ruler recognized his time as a beginning of new order as the founder of Goryeo had done or when radical reform was to be anticipated. For domestic politics weixin was used as a way to expand the power of the throne as seen with King Chungsuk and his son Gongmin; in diplomatic missives it was repeatedly mentioned in regard to territory that had been ruled by Gija, in particular in the area of the Northern border (see map) by former nomadic peoples such as the Khitan Liao. The aim of Chungsuk was to introduce new ingredients of reform into domestic politics was to organize government and at the same time to acquire the justification of power. ${ }^{92}$ The Yuan emperor Renzong (1285-1320; Mongol name Buyantu Khan), who wanted to install Mongol Yuan's cultural elements on top of the foundation of Confucian

\footnotetext{
${ }^{89} \mathrm{Kim}$, Sun-ja. (2009). Conception on the Kitan Liao and Jin Dynasty during the 10th-12th Centuries of the Goryeo Dynasty. Hanguk jungsesa yeongu (The Journal of Medieval History of Korea), 26, 109-150.

${ }^{90}$ Han, Jung Soo. (2012). Aspects of the Calendar System in Accordance with the Establishment and Change of the Relationship between Goryeo, Song and Khitan: from Gwangjong to Hyeonjong. The Study of Korean History of Thoughts, 103-133.

${ }^{91}$ Chungsuk had been a hostage for five years in Khanbaliq (Beijing) due to political friction between the Yuan and Goryeo. When he returned to Korea, he presented a long decree of reform in order to strengthen the authority of his throne and bring changes to the composition of government offices.

92 Park, Dae-Jae. (2006). 49.
} 
values, made it state ritual to worship Confucius, sage kings, and preceding Mongolian rulers. ${ }^{93}$ In relation to the Gija ritual, Lee Kang Hahn suggested that Renzong's organization of the administration, legal institutions and education in accord with Confucian principles was taken as a model by King Chungsuk who saw its potential as a way of acquiring political authority after he knew he had to return home from Beijing after five years of power vacuum in Korea. Although Chungsuk's attempts were not carried out consistently, they were to be continued by his son, Gongmin, who had more favorable support from 'civilized men' led by Yi Je-hyeon $(1287-1367) .{ }^{94}$

Here, it is instructive to briefly examine the status of early neo-Confucianism in the late Goryeo period because it is important to determine the origin of the Confucian statecraft of Jeong Do-jeon and his colleagues. In short, Jeong's voluminous works owe a large debt to Yi Je-hyeon with whom young Confucians, including Jeong bonded as a politicized party. Zhu Xi's neo-Confucianism had been established as the system of state education under the Yuan, and Goryeo Koreans such as An Hyang (1243-1306) and Baek Yi-jeong (1247-1323) were the first to introduce neo-Confucian studies to Goryeo, closely followed by Yi Je-hyeon, Yi Gok and Yi Saek. Yi Je-hyeon, as the most significant official servant to several successive Goryeo kings, was from a scholarly family and married to a daughter of Gwon Bo (1262-1346) who was also an eminent Confucian-scholar and who reportedly introduced the Chinese classics of 'The Four Books with Zhu Xi's commentaries' (Sishu jizhu) to the Goryeo intellectual community. Gwon Bo and Je-hyeon's father, Yi Jin, collaborated in compiling a catalogue of the collection of Confucian learning materials from the former imperial library of the Song dynasty. These had been sent by the Mongol ruler to the Goryeo capital in 1314 in response to the demand of books from Goryeo intellectuals. In the same year, Goryeo King Chungseon, grandson of Kublai Khan, opened a private study called the 'Hall of one-thousand books' which housed a vast collection of Neo-Confucian writings in the Yuan capital. It was here that Yi Jehyeon became closely associated with Yuan Confucian scholars such as Yao Sui (1238-1313), Yan Fu (1236-1312), Yuan Mingshan (1269-1332) and Zhao Mengfu (1254-1322).

It was the Yi Je-hyeon-led faction that appealed to the Yuan for the investiture of Prince Wang Gi (later King Gongmin) after the disruption of kingship in the first quarter of the

\footnotetext{
93 Lee, Kang Hahn. (2010). 3-26.

${ }^{94} \mathrm{Ma}$, Chong-rak. (2005). Goryeoside yugyosa-ui chu-i-wa geseong (Re-reading Confucian thoughts in the Goryeo Dynasty). The Journal of Korean Medieval History, 18, 5-42.
} 
fourteenth century. Any Goryeo prince who returned with investiture from the Yuan court needed to attract allies in order to control the complexity of opposing factions in domestic politics and to ensure the certainty of their position. The state ritual of Gija in the name of weixin best served for justifying their power as a heavenly agent as Gija was believed to have done. King Gongmin, Chungsuk's son whose mother was a Goryeo Korean, followed the path of his father, but with more emphasis on Goryeo cultural identity. ${ }^{95}$ His association of weixin and Gija was used as the reason for regaining control over the north-west region of the Korean peninsula and proved one of most powerful means to centralize kingship.

[I see] now our custom has become that of barbarians, men entering into government offices by luck, granaries empty, neighboring Japanese pirates invading us, and at being odds with the pattern of heaven. As Gija was the messenger of culture and music [civilization from China] so his tablet should be sheltered and worshiped in a shrine in the Prefecture of Pyeongyang. ${ }^{96}$

The significance of Gongmin's rule has been mainly considered from nationalistic perspectives in modern studies. Modern Korean scholarship has considered the Gongmin and Gija discourse from a nationalistic perspective and that the influence of the Yuan on Goryeo Korea was both 'harsh and profound' and even 'unprecedented' in history. This opinion definitely implies condemnation of Mongol nomad customs infused in some aspects of Goryeo culture. Although modern Korean scholars generally typically regard Mongol Yuan influence in Korea as something that was foreign and forcefully imposed and therefore needed to be eliminated, David Robinson has advanced another view. ${ }^{97}$ Using Mongol, Chinese, and Arab written sources he analyses the Mongol Empire during the late thirteenth to the early fourteenth centuries from the perspective of decentralization of Yuan power. According to Robinson, this was a period of diverse political entities in Northeast Asia, in which Goryeo Korea, southern Liaodong, Shandong, and the area northeast of Khanbaliq, were in mutual association. The

\footnotetext{
${ }^{95}$ It is written that when Chunghye was the heir prince, his father, King Chungsuk, scolded him for his Mongolian hair style. Both Chunghye and Gongmin were born to Goryeo spouses of Chungsuk, and Gongmin retained a close relationship with his maternal uncle, Hong Eon-bak, since his time as a prince in the Yuan capital. Hong was a cultured civil official and royal relative who supported his nephew king in pursuing centralization of authority in his early reign. Min, Hyeon-gu. (1998). 274-276.

${ }^{96}$ Goryeosa, sega 38: Min, Hyeon-gu. (1998). 279.

${ }^{97}$ Robinson. (2009). Empire's Twilight: Northeast Asia under the Mongols, Massachusetts: Harvard University Asia Center.
} 
difference between Robinson's approach and that of contemporary Korean scholars is that he attempts to view the history from a regional (northeast Asian) perspective, rather than in terms of individual nation-states. ${ }^{98}$ As evidence of the high degree of porosity in territorial, political, economic, and cultural aspects he has taken into account the rampages of the Red Turbans in the mid fourteenth century. In this period Mongol power was waning and both the structure of their Empire and Mongol-Goryeo relations were crumbling with political groups giving personal and family priority over those of the dynasty, state or cultural unit. ${ }^{99}$ Yi Seong-gye's Joseon established itself as a polity that inherited the law and culture of Goryeo and the territory which had belonged to the early Goryeo. This sense of territorial state was in a more sophisticated form integrated with the concept of 'Little China'.

The individuals who provided the ideology of usurpation were those civil officials who served during and after Gongmin's reign and they were also the students of those who first introduced neo-Confucianism to Korea. The first generation of neo-Confucian scholars including Yi Je-hyeon started to perform funeral and burial rituals modelled on the Zhu Xi's family ritual manual and for kingly education advised kings to read Daxue Yanyi 大學衍義 (Extended Meaning of Great Learning) written by the Song Neo-Confucian, Zhen Dexue (1178-1235). The Zhenguan Zhengyao 貞觀政要 (Essentials about politics from the Zhenguan reign, 627-649) compiled by Wu Jing 吳競(670-749) which had been favoured source of governance among early Goryeo monarchs was now not highly recommendable to the ruler. This was the origin of neo-Confucian principle of governance or neo-Confucian statecraft in late Goryeo period which would continue into the early Joseon and beyond. The task of the civil reformists who signed the impeachment document of their Goryeo king in July 1392 was to bring about certainty of kingship, domestic and international stability. As seen in Chapter One, once the diplomatic requirements were completed with the Ming, the claim to a polity followed.

After the declaration of the end of the Wang Clan dynasty in 1392, the new government sincerely followed the protocols of diplomacy in order to confirm the security of new dynastic rule. In his Code, Jeong Do-jeon tactically documented the identity of Joseon's new polity

\footnotetext{
98 Ibid. 252-284.

${ }^{99}$ In a review of the book by Robinson, Lee, Kang Hahn is pessimistic about Robinson's imposition of the concept of 'integration' [into the order of north east] upon the general situation of Goryeo during $13^{\text {th }}$ and $14^{\text {th }}$ century. See Discussing David M. Robinson's Empire's Twilight: Northeast Asia Under the Mongols. International Journal of Korean History, 16 (1), 1-24.
} 
according to the traditional cultural pride the people held for ancient Gija Joseon. Jeong's ideological commitment as codifier was not a new element, but a product of tradition that was summoned, polished and then driven finally to change historical course of Korea in the fourteenth century. The composition of Jeong Do-jeon's Code will now be examined with respect to the priority of the new political structure that sought guzhi from the Yuan code, Jingshi dadian. The development of Song neo-Confucianism in Goryeo Korea is with importance discussed in terms of its transformation from administrative skills to the source of ideological drive along with Yuan's legal heritage. 


\section{CHAPTER THREE}

\section{LEGITIMACY OF JOSEON}

The purpose of this chapter is to shift from conventional views of the importance of the structure of the Code. It is argued here that Jeong emphasised $l i$ 禮 in terms of hierarchical order as central to the authority of the king, and that this takes precedence over administration in the arrangement in the law book. Lack of understanding of the codifier's editorial venture can be classified as one factor that led to later popular interpretations of the Code as promoting power checks and balance. The innate infirmity of Goryeo kingship is provided as evidence for Jeong Do-jeon's priorities as a classicist deeply engaged with the new order, an order in which he believed ministership would not succeed unless the authority of the throne was first ensured. This is followed by an examination of the resemblance of three law books, Jeong's Code, the Yuan code, Jingshi dadian, and Goryeo Korean Kim Ji's Six Wings of the Zhou Offices (Jugwan yugik) in which I argue that all of these were created to commonly serve the justification of existing dynastic rule.

\section{3-1. Certainty of the Throne}

The Code starts with the declaration of new throne, Jeongbowi 正寶位 (Right Throne) as a constitutional claim to the supreme authority of a polity. It is then followed by Gukho 國號 (State Name), Jeonggukbon 定國本 (Royal Succession), Segye 世系 (Royal Genealogy) and Gyoseo 呚書 (Royal Decrees), all of which deal with the fundamental elements of dynastic rule and they composed the first section of matters pertaining to the throne (junshi 君事). Here, Confucian traditional verses are summoned first for the supremacy of the throne as seen below:

The great treasure of the sage is called authority; the great virtue of heaven and earth is to grow [things]. How to maintain the authority is then, by benevolence. ${ }^{100}$

\footnotetext{
${ }^{100}$ Joseon gyeonggukjeon, sang, jeongbowi, SB 7:1a (2016 Haksunje edition).
} 
The most important thing to note here is that the order of the quoted sentence of Ji xizhuan 繫辭傳 from the I Ching 易經 (Book of Changes) has been changed. ${ }^{101}$ Although the sentences have lost their original parallel rhythm, the effect of the emphasis on the authority of the throne followed by the virtue and benevolence requisite of the ruler seems to have achieved what was desired. There is little evidence either that Jeong intended to change their order so as to emphasize the rightful authority of Yi Seong-gye's enthronement or that he simply mistakenly quoted from memory. ${ }^{102}$ However, given that memorizing Confucian classics as they were was indispensable for students to be successful for state exam, so it is probable that he altered the order on purpose to emphasize the authority of the throne. Only after claiming the incomparable authority of the ruler did Jeong Do-jeon add that the "authority would be maintained when the ruler governed the people by virtue of benevolence; then those with skills and good nature would come forward to serve the government; and those with martial skills and a bold mind would serve with their hearts; therefore, the people would occupy themselves with the work allocated to them and be subjugated only to the ruler."103 "Your Highness is the only ruler", Jeong proclaimed, "who has made the throne right as soon as he obeyed the will of Heaven and the mind of the people, who knew and realized the imperative of Heaven in his mind". ${ }^{104}$

It is true that the axiom of benevolence emphasized as the primary principle of moral politics in Confucian statecraft could be used by all the actors involved in power struggles, and for contradictory purposes: for justification of both usurpation and maintenance of an incumbent ruler. What happened at the end of Goryeo rule is helpful to compare what occurred at the beginning of the new dynasty and at the same time to witness same application of the traditional phrase in these two different ways:

Surrounded by Goryeo subjects, the last Goryeo king was read the decree of the late King Gongmin's Dowager Queen instructing the transfer of the royal seal to a member of the Council (Dopyeong eusasa 都評議使司, or the shorter name, dodang). Four days later general Yi Seong-gye (1335-1408), at his private residence in Gaegeong, the capital of Goryeo, accepted the royal seal that marked the end of the Goryeo dynasty. ${ }^{105}$

\footnotetext{
${ }^{101}$ Kim Yong-oak (2004) notes that the later part 'heaven and earth' should come first.

102 Kim Yong-oak interpreted this as Jeong Do-jeon's intention to emphasize the authority of the new throne, Yi Seong-gye. Kim, Yong-oak. (2004). 12.

${ }^{103}$ SB 7:2b.

104 Ibid.

105 JWS, 1, 1:37a.
} 
The last Goryeo king was read that he had acted against the Mandate of Heaven with darkened mind for benevolent governance. The dynastic change in Korea, not by foreign invasion or exploitative rule, but by impeachment of the ruler by officials, 'was rare, this being the only one in the thousand years preceding Japanese colonization in 1910.' ${ }^{106}$ How could behavior like this, with the potential to be criticized as unethical by Confucian moral standards be justified? The matter of who these 'unethical' subjects were has long been an important question in the study of the origins of Joseon. Because of emphasis on the incorporation of moral principles into legality in the Code, the issue of who was considered to have acted immorally is important. Nevertheless, what should be considered in the dynastic change is that the officials who stood against their ruler blaming him for lacking the Mandate of Heaven very soon found themselves standing on the opposite side, having to justify the new power. The arguments used to deprive the ruler of Goryeo of legitimacy were to be employed in reverse. What Jeong Do-jeon relied on for the task of arguing the source of legitimacy for the new dynasty were the following three aspects: the justification of the progenitor of Joseon, the legitimate heir apparent and the enforcement of royal decrees. All are addressed in order below.

The primary task of the justification of new polity was to acquire approval for it from the Great Ming and to win the hearts of people of Korea. The first article of the Code, Right Throne, dealt with this question, and the second article in the Code, with the question of the State Name. This article described the origin of Joseon name and its relations with Chinese Zhou dynasty in the past, as discussed in the previous chapter. As the Gija Joseon rhetoric had been recognizable to those familiar with the Chinese Classics, its use has been interpreted as a political strategy to soften the diplomatic tensions with the Ming court. ${ }^{107}$ Jeong Do-jeon seems to have known best to bring an end to the uncomfortable relationship between Ming and Joseon by providing the best compliments to the Hongwu Emperor; he compared the virtue of the Emperor to that of the Duke of the Zhou dynasty and Yi Seong-gye to Gija who inherited civilized law and culture from the Duke of Zhou. Jeong ended this article saying that, "the new Joseon would be a country seeing the law of Gija prospering more than Confucius would have dreamed of." 108

\footnotetext{
${ }^{106}$ Duncan. (2000). 3

${ }^{107}$ Huh. (2015): Oh (2014): Han. (1999).

108 SB 7:2b.
} 
The fifth article of the Code, Royal Decrees, argues for the power of the throne to be realized in due procedure of policy making. It was again a contribution to the confirmation of the status of the Joseon dynasty as a vassal country of the Great Ming. ${ }^{109}$ As Prince of Joseon, nominally any royal document was to be called 'gyoseo' 呚書, rather than chikseo 勅書 as the latter term had referred to imperial edicts made by Chinese emperors since the Han dynasty. After a century of Yuan control, the rearrangement of hierarchical order between imperial edicts and decrees (gyoseo) was one of many ways of identification of a polity in the fourteenth century East Asia. "In this time of restoration, weixin," Jeong wrote, "all royal decrees are delivered in the capital and to the countryside". By ending the article saying that there was no distinction regarding the authenticity of the decisions either by emperor or king the supremacy and legal enforcement of kingship was reclaimed.

Related to the draft and proclamation of the Joseon's first royal decree there is an incident that shows the power transition did not precede seamlessly. Jeong Do-jeon was responsible for drafting the first Joseon royal decree of $1392^{110}$ but it was delivered to the public without the initial approval of Yi Seong-gye. Among the decisions of the decree was the execution of several officials who had bullied him for his mother's low-class origin. One of these was his tutor the National Confucian Academy. It is understandable that it was too early for royal matters to be settled by following fixed protocol but at the same time this case has often been consulted as evidence for Jeong's abuse of power as a secretariat, ${ }^{111}$ and it is possible that the absolute prime ministership in the government embedded in the Code could be a result of Jeong's political ambition as a minister in anticipation to occupy the position in favour of new monarch. This interpretation is naturally a denial of the status of the Code as part of official Joseon documents. There is, however, no way to prove Jeong's intention. Regardless of his purpose of personal advantages, the effect that accompanied Jeong's codification, consciously or consequently, is that which needs more focus of investigation in the set of circumstances of dynastic change.

\footnotetext{
109 SB 7:4b.

${ }^{110}$ This is titled pyeonmin samok (Matters concerning the convenience of the people) consisting of seventeen articles. JWS, 1, 1:42b.

111 The last article of the inaugural announcement is a command to punish those who had not supported Yi Seonggye including Yi Saek and U hyeon-bo. But, as an additional description reveals, it was drafted by Jeong Do-jeon and some of the names listed by him were likely to have been political opponents.
} 
Another traditional tactic to establish a new kingship is the production of royal genealogy and saga of the progenitor of the dynasty as a formula of dynastic foundation, and this is also apparent in the contents of history of Goryeo. The following third article, Royal Genealogy, is loyal to this formula but at the same time it contains general principle of compiling the family tree of the new Yi royal clan. It did not take more than ten days before the end of Goryeo in 1392 for Jeong Do-jeon to complete the ritual procedure of endowment of posthumous titles to the four generations of the progenitor of Joseon, (although these are not included in the Code). ${ }^{112}$ The ancestral claim to the honourable titles of sage kings such as the King Wen and King Wu of the Zhou dynasty was described succinctly, beginning with Jeong's personal inspiration of the Book of Documents. ${ }^{113}$ The simplicity of this claim, as we will see later, reaffirms the suggestion that the task that Jeong Do-jeon perceived most important in the creation of the Code was not to compile all information but to materialize the legal supremacy of new Yi clan dynasty. This is also supported by the fact that the task of compiling precedents and cases since 1388 was given to Jo Jun, another early Joseon lawmaker. Kim In-ho has placed more emphasis in a study of early Joseon legislation on the six legal corpora system begun by Jo Jun's 1395 compilation of Gyeongje yukjeon 經濟六典 (Six Canons for Governance). ${ }^{114}$ In his discussion the governance code of Jeong Do-jeon was interpreted as a preliminary study or report to the king. Regardless, when it comes to all the concurrent titles and duties Jeong was given in the first three years of the new dynasty, it is not unreasonable to assume that he had no time to commit to production of other legislation. Rather, being well-versed in ritual propriety $(l i)$ and ritual music, Jeong Do-jeon seemed to be more concerned with such fundamental issues as bringing certainty and stability to the throne and royal line. Despite the paucity of content, the structural arrangement of these three articles serves overall the purpose of the glorification of new throne as the head of state.

The title of the third article on royal succession, Jeonggukbon 定國本, means literally 'determination of the root of state', because succession has often been at the centre of the certainty of state institutions. As royal succession had never been smooth in dynastic history, particularly in the case of last three Goryeo kings, so it could be another major component of the new dynastic rule to be established as soon as civil-order was decided. Interestingly, it is in

\footnotetext{
$112 J W S, 1,1: 42 \mathrm{~b}$.

${ }^{113} S B$ 7:3b.

${ }^{114}$ Kim, In-ho. (2002). Yeomalseoncho yukjeon cheje-ui seongnipgwa jeonge (The Establishment and Development of the Six Codes System in the Late Koryo and Early Choson Dynasty). Dongbang hakji, 118, 139.
} 
this article of the Code that Jeong Do-jeon attempted to confirm the royal succession of heir apparent, Pangseok (1382-1898), as his senior tutor. Jeong's concern can be read between the lines of the third article. Jeong began with the general principle of inheritance of the throne by the eldest son. This ran parallel with the axiom that the candidate to the throne should also be the wisest, because, as Jeong explained, without virtue and knowledge, no one could be a successful ruler responsible for serious state affairs. This was also was why the heir apparent should be guided by seniors with recognizable virtue and wide range of knowledge so that he would be able to correct his language and behaviour through their guidance. ${ }^{115}$ However, without mentioning whether the principle was to be maintained regardless of time and place, Jeong digressed by denouncing historical examples where royal candidates had been wrongfully guided so that they were distracted from self-cultivation and consequently had their titles removed. ${ }^{116} \mathrm{He}$ then proceeded to provide a description of the installation of the existing crown prince according to the will of the dynastic progenitor, complementing his day-by-day development with his enthusiasm for learning and mildness of personality. Jeong Do-jeon ended this section on the royal succession by once again emphasizing that the "authority of the crown prince should be solidly established, for this puts the foundation of the state on a solid basis." 117

The matter of the heir being the eldest or being the wisest had often been at the centre of political debates in the courts of Chinese dynasties. The early Joseon government faced the same dilemma with the appointment of the heir-apparent. The dynasty's founder, Yi Seonggye, preferred the youngest son of his fourth wife Lady Kang to any of other seven sons from other spouses. His decision to choose him as heir stirred tension among the supporters of Yi Seong-gye and among his siblings, whose involvement in politics and even in armed struggles could not be ignored. In particular his fifth son, Yi Pang-won, who was capable of passing the civil service examination and possessed military skill, was unhappy with Yi Seong-gye's preference. Jeong Do-jeon, who at first did not agree with the founder's preference, ${ }^{118}$ later acquiesced and helped the heir-apparent study a meticulously specified curriculum involving open lectures and reading classics with scholars and officials. This is the reason that Jeong Dojeon made a compromise between the two principles of the eldest son's inheritance of the

\footnotetext{
115 SB 7:3a.

116 Ibid.

117 SB 7:3b.

${ }^{118}$ Han Young-woo. (1999). 55.
} 
throne and the implication that the crown prince, the youngest, was wise and capable enough to be entitled to the throne. These were the background circumstances to the significance of the 'Royal Succession' part of the Code. Four years after completion of the Code, Jeong Do-jeon and like-minded officials were executed without trial on a charge of treason by the would-be heir-apparent Yi Pang-won. Succession to the Joseon throne was then manipulated by Pangwon through bloodshed, resulting in his eldest brother being placed on the throne. Thereafter Pang-won induced him to retire in favour of himself. ${ }^{119}$

The weakness of Han Young-woo's interpretation of the core of the Code as a claim to prime minister-centred government in terms of power separation is his failure to notice that the king's power had never been dominant in Goryeo politics to begin with. On the contrary, Goryeo monarchs from the beginning were one of many players of court politics and had to seek alliances with other players in the council and bureaucrats to ensure their kingship. Here, the power of the ruler does not necessarily mean to counterbalance the power of bureaucrats in the other end of the formula. In general, it can be said that the capacity of the bureaucrats in handling the state affairs increased as long as the king's power was to a certain degree ensured among military and aristocrats' occupation of state resources. The Goryeosa provides circumstantial evidence that abuses of power by rulers were not the cause of the end of the dynasty. All compilations of the history of dynasties in pre-modern East Asia were written by the succeeding dynasties to justify their own dynastic rule by seeking reasons for dynastic change in the foregoing dynasty such as immoral practice of power or exploitative ruling of people by heavy taxation. What has been reasoned for the demise of Goryeo was not quite different from general troubles that Chinese societies had: malfunctioning taxation systems, expansion of large manor landholdings of aristocracy and the fragility of civil-order to military power. The early Joseon historians attributed the crisis of the previous dynasty to polarized politics contaminated by the greed of powerful families in high positions, not of Goryeo rulers themselves. Additionally, given that the last three Goryeo rulers were respectively usurped, exiled and killed by those holding power in the court, it is incorrect to premise that the Code of 1394 was compiled out of concern of the abuse of the power by monarchs.

\footnotetext{
${ }^{119}$ Palais, J. (1996). Confucian Statecraft and Korean Institutions Yu Hyongwon and the Late Chosun Dynasty, Seattle: University of Washington Press, 32. Part I of Palais' book, 'State craft in founding Joseon' provides a well-rounded overview of early Joseon statecraft.
} 
Studies of the institutions of Goryeo contain little dispute over the nature of the weakness of Goryeo kingship. Shultz, ${ }^{120}$ Duncan and Kim Tang-taek ${ }^{121}$ have shown agreement that the institutional difficulties of the late Goryeo were deeply rooted in the origin of the Goryeo regime, so historical background is helpful for fuller understanding of the crisis of late fourteenth century Korea. The Goryeo dynasty began with vulnerability usurpation by military lords and rebellion, because the founder of Goryeo, Wang Geon (王建 877-943), was little more than the first among equals ${ }^{122}$ of a confederation of powerful warlords. Having relied on the cooperation of local aristocracy, which stemmed from local power centres of the previous united Silla period (新羅 671-918), Wang Geon and his successors used a mix of institutional and non-institutional measures, including bloody purges, to pursue a policy of centralization. It was a matter of urgency in this early stage of the dynasty to first consolidate the royal family's control over state affairs. ${ }^{123}$ The initial stage of this process was followed by enhancement of the prestige and authority of central government by institutional organization, and then by extension of direct central authority over the countryside. ${ }^{124}$ The progenitor of Goryeo also knew well that the importance of legitimization of authority relied on traditional Buddhist ideology. On his death bed he left oral messages for posterity called the 'ten instructions' hunyo sipjo (chi. xunyao shitiao 訓要十條) ${ }^{125}$ in which he emphasized that the adoption of traditional Confucian principles of governance and patronage of Buddhism were essential for the unity of the state. In addition, he was also cautious to stipulate that the military should be well taken care of. Thus, although the first Goryeo monarch's policy was limited to a relatively low level of institutionalization, his 'ten instructions' helped his successors to be cautious about the organization of court politics. Although two sons subsequently inherited the throne of the founder under rather unstable political conditions, Gwangjong (光宗 r. 949-975), the fourth ruler, and the fifth ruler Gyeongjong (景宗 r. 975-981), achieved primacy of royal power in central government through more articulated institutionalization.

\footnotetext{
${ }^{120}$ Shultz, E. (1988). Twelfth-Century Koryŏ Politics: The Rise of Han Anin and His Partisans. The Journal of Korean Studies, 6, 3-38: (1979) Military Revolt in Koryŏ: The 1170 Coup d'État. Korean Studies, 3, 19-48.

${ }^{121}$ Kim, Tang-taik. (1986). Goreyo muinjeonggwon yeon-gu (Studies on the Goryeo military government).

Seoul: Saemunsa.

${ }^{122}$ Duncan. (2000; 14).

${ }^{123}$ Wang Geon used various measures to expand his royal bloodline and subordinate local power clichés: he arranged intermarriage ties with twenty-nine daughters of war lords, had family members of supportive warlords serve in his court and incorporated them into the Wang clan by offering them his surname. Schultz examines the Goryeo period in the context of a civil framework. Shultz. (2003). Courtiers and Warriors: A Search for Equilibrium in Koryo Society, 400-402.

${ }^{124}$ Duncan. (1998). The Formation of the Central Aristocracy in Early Koryo. Korean Studies, 12, 42.

${ }^{125}$ Kim, Seok-geun. (1999). Hunyosipjo (訓要十條)wa simuyisippaljo (時務二十八條) (A Sketch of Political Thoughts of the Early Goryeo Dynasty). The Journal of Asiatic Studies 6, 337-369.
} 
Measures to add to the prestige of the king's authority and to nurture meritocracy were introduced and both found way to function in way that kingship and bureaucrats complemented each other when they were in rivalry with the military and gentry. With the leverage of differentiated institutional bodies came a degree of specialization and differentiation of meritocracy by the twelfth century. Before long, the civil order was upended by the 1170 military coup that began a century of military rule behind the puppet rulers they erected lasting until 1270. The political crisis of Goryeo arising from the fragility of the throne did not disappear after military rule ended with the Mongol invasion in 1234. By capitulation to the Mongols in 1259, The royal house of Goryeo could extend its survival under the umbrella of Yuan, the Chinese Empire the Mongols founded, but they soon found this was as harsh than the domestic military dictatorship. As will be seen in following chapter, from then on, changes in the institutions and administrative structure of Goryeo were frequent thanks to the factional landscape of the Yuan court. The 1287 establishment of the directorate office (Jeongdongheng jungseoseong 征東行中書省) made it unavoidable for the Prince of Goryeo as a servant of the Yuan emperor to conduct military campaign against Japan on behalf of the Yuan. So was the investiture of Goryeo fallen under the hands of inner few powerful in the Yuan court.

Although the peace treaty with the Mongols signed after twenty-eight years of military campaigning (1231-1259) ensured that Goryeo could maintain their culture and royal line, the Yuan dynasty imposed a tribute-investiture system on Goryeo. Traditionally, the investiture system rested on ex-facto approval, and dynasties in Korea could maintain their political and cultural autonomy. However, as Goryeo was incorporated into the Yuan-dominated order in East Asia, the grades and nomenclature of government officers were downgraded to reflect the status of the country, and the Goryeo bureaucracy experienced the ascendency of alien Yuan elements over the next century. Thus, the status of Goryeo rulers was downgraded in the traditional Chinese international political order, and the posthumous titles were changed by official decision of the Yuan court; now being titled the Prince of "Goryeo Korea" where the characters, zhong 忠 (loyal to Yuan) and wang 王, rather than zong 宗 or $z u$ 祖 which were the same as imperial titles. The Yuan court, however, knew well that it needed to guarantee the Prince of Goryeo Korea a certain level of autonomy so that they could be called upon to meet 
the needs of Yuan state projects such as military campaigns against Japan, for which a vast amount of social resources was needed. ${ }^{126}$

When crisis comes from outside, so does the attempt to bring certainty within inside. It is noteworthy regarding intellectual effort to justify the institutional basis of Goryeo dynasty that the composition of Yi Seung-hyu (李承休 1224-1300), Jewang ungi 帝王韻紀 (Song for Kings and Emperors), appeared in 1287. Yi's composition comprised the verses singing for the virtues of the rulers of previous kingdoms of Goryeo Korea as well as the legendary sage kings and emperors of China. As seen in the previous chapter, Yi traced a Korean cultural identity back to the time of Gija and Duke of Zhou. Attention should be drawn here to the date of the appearance of the work soon after Goryeo royal princes were forced to move to and reside in the capital of the Yuan as political hostages. Yi re-organized traditional narratives in way to declare the legitimacy of the Goryeo throne. From this time onwards, maintenance of the 'royal shrine' and the 'altars of the gods of crops and earth' came to appear more often in personal works and government documents of court dialogues. It is likely that the sense of crisis of their monarchy to have made Goryeo intellectuals utilize cultural norms as means of legitimization of their dynasty. When we bring the story back to the Code and Joseon, what changes do we find? What is new in the political design of Jeong Do-jeon? What Jeong Do-jeon summoned to the task was moral politics, the same source of legitimacy of any incumbent power. However, the resemblance of the structure of the Code and the 1331 Yuan code, Jingshi dadian, is far more than about the format but the way that informal values were organized in hierarchical order in legal documentation. More focus is given on the formalization of ritual propriety $l i$ than on the legislative aspect of the Code that has caused conventional debates over the essence of the Code.

\section{3-2. Form Matters: The Adoption of the Jingshi dadian}

The order of elements in the Code defines how ideas in it are conveyed. The adoption of the structure of the Jingshi dadian mattered in the Code as the form itself tells a lot. The Code was comprised of two sections: matters pertaining to the throne (junshi 君事); and matters of government affairs according to six legal corpora (chenshi 臣事). The first part conveys five

\footnotetext{
${ }^{126}$ Lee, Jeong-Hoon. (2015). Wonganseopgi chinjowa gamguk (Chinjo and Gamguk during the early Yuan Intervention period). The Journal of Korean History, 171, 101-132.
} 
general principles of the institution of kingship while the second is made up of six corpora of Personnel, Revenue, Rites, War, Justice and Public Works containing a hundred and two articles dealing with fundamental issues of administration. As seen above, the first part contains the fundamentals of dynastic rule as a polity such as the legitimate kingship, state name, royal succession, royal genealogy and royal command. Suematsu Yatsukazu (1904-1992), the Japanese law expert, discovered in 1920s that the format and context of the Code was almost identical to those of the Jingshi dadian, 經世大典, as seen in Table $1 .{ }^{127}$ By reorganizing the articles of the extinct Yuan law book, Jingshi dadian, consulted in the selected writings of the Yuan, Guochao wenlei 國朝文類 (literally “Categorized literature from Our Dynasty”, compiled in 1334 by Su Tianjue), Suematsu identified the contents and the similarities of the two codes to whom modern Korean scholarship of Jeong's Code has owed. By providing a sketch of Yuan law compilation history, how Jeong Do-jeon reflected the conditions of his time in the editorial venture is illustrated in the table below.

Matters of the Ruler (junshi 君事)

\begin{tabular}{|l|l|l|l|l|l|l|}
\hline & $\begin{array}{l}\text { Name of } \\
\text { Empire }\end{array}$ & $\begin{array}{l}\text { Imperial } \\
\text { Instruction }\end{array}$ & $\begin{array}{l}\text { Imperial } \\
\text { Succession }\end{array}$ & $\begin{array}{l}\text { Imperial } \\
\text { Genealogy }\end{array}$ & $\begin{array}{l}\text { Sup. } \\
\text { Imperial } \\
\text { Genealogy }\end{array}$ & Dixifulu \\
\hline JD & $\begin{array}{l}\text { Dihao } \\
\text { 帝號 }\end{array}$ & $\begin{array}{l}\text { Dixun } \\
\text { 帝訓 }\end{array}$ & $\begin{array}{l}\text { Dizhi } \\
\text { 帝制 }\end{array}$ & $\begin{array}{l}\text { Dixi } \\
\text { 帝系 } \\
\text { 帝系附錄 }\end{array}$ & \\
\hline JG & $\begin{array}{l}\text { Jeongbowi } \\
\text { 正寶位 }\end{array}$ & $\begin{array}{l}\text { Gukho } \\
\text { 國號 }\end{array}$ & $\begin{array}{l}\text { Jeonggukbon } \\
\text { 定國本 }\end{array}$ & $\begin{array}{l}\text { Segye } \\
\text { 世系 }\end{array}$ & $\begin{array}{l}\text { Gyoseo } \\
\text { 喏書 }\end{array}$ \\
\hline & $\begin{array}{l}\text { Right } \\
\text { Throne }\end{array}$ & $\begin{array}{l}\text { State } \\
\text { Name }\end{array}$ & $\begin{array}{l}\text { Royal } \\
\text { Succession }\end{array}$ & $\begin{array}{l}\text { Royal } \\
\text { Genealogy }\end{array}$ & & Royal \\
\end{tabular}

Table 1. Articles of Matters of the Ruler in Jingshi dadian (JD) and Joseon Gyeonggukjeon (JG)

As seen above, the entire structure and the order of articles of Jeong's Code is a copy of the Yuan Code, Jingshi dadian. It is not known, however, that this Yuan code, a repository of 800 fascicles of official documents and laws, was ever printed out. Only about five percent

${ }^{127}$ Suematsu Yatsukazu (1943): Jung Geung Sik (2016). 87. 
of the text is recorded in the Guochao wenlei 國朝文類 and in the Yongle dadian 永樂大典 (Great Encyclopaedia of the Yongle Reign-period) completed in 1408. ${ }^{128}$ The articles of the Yuan code known today were those abstracted from articles of the Jinjingshi dadian 進經世大 典, written by $\mathrm{Ou}$ Yangxuan (1274-1358), and the preface of the Yuan code, Jingshi dadian $x u l u$, written by Yu Ji (1272-1348) quoted in chapters 40 to 42 in the Guochao wenlei. ${ }^{129} \mathrm{In}$ the format of the arrangement of regulations and ordinances, the Yuan legislators used the codes of Tang and Song of China such as the Six Law Canons of the Tang (Tang liudian 唐六 典). The Tang liudian provided detailed provisions regarding the state organs, the appointment of officials, functions and obligations of each offices and their officials. ${ }^{130}$ The significance of Jingshi dadian in Chinese law history, however, was limited due to fragmentation of the original source text until the 1920s when Suematsu Yatsukazu produced a meaningful clarification. Subsequently, it was revealed that the Yuan code was the first dual format law book not only including imperial edicts and regulations but also state institutions and neoConfucian principles of governance. Although only the article titles are known, and not the contents, the structure itself allows a determination of the purpose and effect of such format of law book. A glimpse of the development of Yuan legislation can provide background of the compilation of the 1331 code from a different perspective in the legal history of China.

Researchers agree that the new phase of Yuan's legislation development down to the Jingshi dadian should be sought in the territorial extent and demographic nature of the empire. It did not take long after they declared their empire in 1270 before the Yuan embarked on a project of legislation. Mongol laws relating to the army, court, and imperial administration were customary punishment laws. The pronouncement of Genghis Khan and his successors were interpreted in the light of unwritten custom, and up to 1271 Mongols and peoples in Central Asia were subject to Mongol customary law, while Han Chinese were subject to the Jin code of 1202. In the early period of the Great Yuan, Mongol ruling tribes led by Kublai Khan were well aware of the significance of legal institutions to manage their empire with its

\footnotetext{
${ }^{128}$ Wilkinson, E. (2015). Chinese History, A New Manual (4th edition), Harvard University Asia Center, 781.

${ }^{129}$ Jung, Geung Sik. (2016). 103. Tables of the entries of the Gyeonggukjeon and Jingshi dadian are taken from Jung's work.

${ }^{130}$ Chen, J. (1999). Chinese Law: towards an Understanding of Chinese Law, its Nature and Development. Boston: Kluwer Law International, 126.
} 
various cultural and ethnic components. ${ }^{131}$ The early form of Yuan legislation was a collection of various laws, edicts, and precedents utilized for civil and criminal regulations. Following the comprehensive collections of regulations, precedents and cases in 1291, Zhiyuan xinge 至 元新格, ${ }^{132}$ came the Yuan dianzhang 元典章 (Statutes of the Yuan Dynasty) ${ }^{133}$ before 1322 , the Da yuan tongzhi 大元統制 (comprehensive regulations of the Great Yuan) ${ }^{134}$ in 1323 and then the Jingshi dadian in 1331. From major characteristics of penal laws of previous codes, what attracted the attention of researchers in the scholarship of early Chinese legal history was the way the Mongol penal system adjusted to the existing Chinese cultural environment, and how different sources were integrated for the management of the empire.

Early scholars of this topic discovered that the format of Jingshi dadian parallels that of Yuan dianzhang, but their focus was more on analytic comparison of the two to determine the interactions of Mongol and Han Chinese legal traditions. In a comparative study of 'Mongol law and Chinese law in the Yuan dynasty', V.A. Riasanovsky noticed new factors in the compilations of Yuan dianzhang and Jingshi dadian. However, his study still remained at the level of comparative analysis revealing the structural features of the two, leaving political implications what law makers might have intended by the specific format of dual structure untouched. Instead he identified that the Yuan dianzhang is divided into ten categories of which the first two sections deal with, 'Wise Government', contain edicts of Yuan emperors from Kublai to Shodi Bala. ${ }^{135}$ Of the total the ten sections, the first four (including the two of imperial edicts) are related to the imperial family, the capital, taxation, principles of ruling, while the latter six sections are concerned with rules for the administration of six ministries dealing with ranks, civil and financial affairs, ceremonies, war, criminal affairs and

\footnotetext{
131 The 1291 Zhiyuan xinge was not a formal code but another collection of regulations, precedents and cases that has been reconstructed with annotations by Ch'en, Paul Heng-chao. (1979). Chinese Legal Tradition under the Mongols: The Code of 1291. Princeton: Princeton University Press.

${ }^{132}$ For the English translation see Ch'en. (1979).

${ }^{133}$ It was ordered to be compiled during the reign of Emperor Chengzong 成宗 (r. 1294-1307) so that all local administration units collected edicts concerning legislative matters as to compile a code. Yi, Linzhen. 亦鄰真 (1992), Yuan dianzhang 元典章. Zhongguo da baike quanshu 中國大百科全書, Zhongguo lishi 中國歷史 (Beijing/Shanghai: Zhongguo da baike quanshu chubanshe), 3, 1453-1454.

${ }^{134}$ Da yuan tongzhi is known to have contained ordinances and statutes similar to administrative regulations compiled in 1316, was proclaimed in 1323. It originally contained 2,539 entries but today only 653 entries from the tiaoge (ordinances) are extant. Wilkinson (2015).782. It was compiled according to the six canons system for the first time in the legal history of China.

${ }^{135}$ V. A. Riasanovsky, Mongol Law and Chinese Law in the Yuan Dynasty. 266-289. This examines the suggestion of Professor Popov that the Yuan dianzhang with its extension, Zhizhi tiaoli, is the code which was translated from the Mongol containing references to the Great Yassa of Genghis Khan. By examining the laws of the Yuan codes, Riasanovsky concluded that although there are several references to articles of the Great Yassa of Genghis Khan in the Yuan dianzhang, the influence is very slight.
} 
construction, respectively. It comprises four sections of imperial matters and six sections of administrative affairs like the following Yuan code, Jingshi dadian. The first section, 'Wise Government', for example, comprises the edicts of the Emperor Kublai 'on accession to the throne, on the selection of a capital, on the naming of the Great Yuan dynasty'. It is apparent that the 1331 Yuan code has a greater degree of structural organization than the 1322 code, yet there is strong resemblance in the structure between the 1322 code and the Goryeo law book, Jugwan yugik by Kim Ji, which discussed is in detail in the next Chapter. Although little has been written on the possible influence of the Yuan dianzhang on Jugwan yugik, except the fact that they were composed according to the Zhouli system, a full investigation of the matter of a possible link between the two law books is called for. The little attention given to it until now is largely due to Han Chinese cultural tradition-centred studies that have separated the Mongol Yuan's influence on neighbouring countries' law from traditional Chinese civilization. Korean scholarship up to the 1990s also risked narrowing its perspective of the legal history of Korea into the discontinuity between the Yuan and Ming or the Goryeo and Joseon dynasties for the same reason. ${ }^{136}$ As will be discussed in the next chapter, the continuity of legal institutions of the Goryeo and Joseon dynasties offers critical support for the continuity of the Code, which is likewise critical in befitting the cultural orientation of Jeong Do-jeon.

Legislation cannot be realised without the specific purpose of those involved in its creation, in particular those concerned with dynastic rule, so the political background of the compilation of Jingshi dadian is most critical to better understand its resonance in Jeong's Code. The Jingshi dadian was compiled in the Mongol language in 1331 during the reign of Togh Temur (posthumously titled Wenzong: r. 1328-1329, 1329-1332). ${ }^{137}$ The law book described that "[offices] were divided into six according to the Office of Heaven, Office of Earth, Office of Spring, Office of Summer, Office of Autumn, and Office of Winter, above all of which was the Office of Mongols, Mengguju 蒙古局, responsible for state affairs." ${ }^{138}$ The compilation was conducted by two separate institutes - the Academy Institute, Kuizhangge

\footnotetext{
136 Jerome Bourgon and Pierre-Emmanuel Roux. (2015). The Choson Law Codes in an East Asian Perspective, 19-51, in The Spirit of Korean Law: Korean Legal History in Context (ed.by Marie Seong-Hak Kim). In part, this was because legal studies in Korea had focused on penal laws imported from China and less was known about the Yuan's punishment law and its adoption into the Goryeo system.

${ }^{137}$ Yuanwenlu, 41, Jingshidadian xulu, for the historical background of the six canons system of Jingshi dadian, see Jo, Won. (2017a). Wonhugi beopje-e natanan yukjeonjedowa geu yeonghyang (The Six Canons System of the Yuan Law Books and Its Influence - the six canons system of Jingshi dadian). Collected Papers of Seminar of the History of East Asia, 219-233.

${ }^{138}$ Yuanwenlu. 41, Jingshidadian xulu: Jo. Won (2017a). 222.
} 
xueshiyuan 奎章閣學士院, made up of mostly Chinese scholars for the six ministries, and the Office of Mongols, composed of Mongol intelligentsia, for matters of the ruler. Regarding the political background of this compilation the most convincing suggestion is that it was due to the competition for the throne among imperial Mongol tribes. ${ }^{139}$ Once conflict ended with victory of a certain imperial lineage, this new lineage was required to compromise contradictions among edicts issued by precedent emperors over imperial succession matters. In addition, new imperial genealogy needed to be legitimately documented. These efforts to justify a new power in terms of a legal format that could have led to the renovation of a dual structured law book. Also, as seen in the Yuan dianzhang, regulations for government had already been compiled in various forms of codes, so there was a need to reorganize imperial lineage-related cases or precedents which may have been contradictory to the political interests of a new emperor.

Another Japanese scholar, Hanamura Yoshiki, shed light on the connection between three compositions, Kim Ji's Six Wings, Jeong Do-jeon's Code and the Yuan Code, but this early literature on the Code, however, has focused on its philological aspect. Their form has been researched only regarding six corpora system within the Chinese traditional legislation system, but the intention of the dual structure of the Yuan Code and Jeong's Code has been given no appropriate investigation. The incorporation of traditional ideas of legitimacy into legality is more than circumstantially evident in Kim Ji's Six Wings of Zhou Offices, and one supposes this was to serve to establish king's authority on a solid foundation. The Six Wings is estimated to have been created somewhere between the early 1370s and late 1380s on account of the nomenclature Kim Ji used for Goryeo offices. ${ }^{140}$ Although there is no way to estimate the time span of the compilation of Six Wings, its form and contents tell more historical facts. As its title explicitly states, the Six Wings is constructed in the format of the six offices as in the Zhouli or Zhouguan, which leads readers to suppose it was about organization of government offices. However, surviving quotes from the Jugwan yugik in the veritable records of the Joseon dynasty, i.e., 'Annals of the reign of Sejong' and the 'Compendium of Korean Geography', show that the original work also contained information of royal genealogy, origins

\footnotetext{
${ }^{139}$ Jo, Won. (2017b). Wonhugi gyeongsedejeonui pyeonchangwa yukjeoncheje (The Compiling of the Chingshih ta-tien of the Late Yuan and the Six Code Construction). Doyangsahak yeongu (Journal of Asian Historical Studies), 141, 299.

${ }^{140}$ Kim, In-ho. (2001). Kiji-ui jugwan yugik yeon-gu (A Study of Kim Ji's Jukwanyukik) Yoksawa Hyonsil: Quarterly Review of Korean History, 40, 128-162.
} 
of the Goryeo dynasty related to the founder of Goryeo, and the localities of specific clans. ${ }^{141}$ Without difficulty one can suppose that the origin of the determination of the Goryeo capital was to demonstrate the emphasis of the Wang clan and their foundation of the Goryeo dynasty. It is described in a traditional way of verses mystifying the origin of the progenitor of a dynasty:

Do-seon, the Buddhist monk, returned after having been tutored in the learning of fengshui (geomancy) by a Chinese monk. One day while travelling to Mt. Baekdu he came upon a house under construction and gave some words to the owner of the house, Sejo [father of the Goryeo progenitor]...Sejo followed the advice given by the monk and indeed got a son as the monk had foreseen. The son was the founder of the Goryeo. $^{142}$

The fact that this information is identical with the records in the royal genealogy of the official history of the Goryeo dynasty, Goryeosa, shows that the Six Wings was not creative literature but instead had characteristics of traditional compilation of history of a dynasty, which has often been undertaken when uncertainty prevailed the society. In another word, concern around insecurity of kingship as the head of state could have led to the birth of the composition. Given that two successors of Gongmin were enthroned in politically fragile conditions, such an attempt to justify the continuation of the Wang clan royal succession is very likely circumstantial. When King $\mathrm{U}$ was enthroned he was a ten-year-old whose power was entirely reliant on his relatives with military background; after his twenty-year reign was finished by the 1388 coup by Yi Seong-gye, his seven-year-old son was put on the throne. Both were usurped, exiled and then murdered in 1388 and 1389 under the slogan of "to abolish the untrue; to set up the true", ${ }^{143}$ and one of advocators of the scheme was Jeong Do-jeon. Therefore, if it is acceptable in a broad time span to assume the date of Kim Ji's work, somewhere in the early reign of King $\mathrm{U}$ is most circumstantially convincing. Evidence that Kim Ji had knowledge of the Yuan Code comes from the inclusion of geographical information

\footnotetext{
141 JWS 55, 151:11b. Kim, In-ho. (2001). 149.

142 Ibid.

${ }^{143}$ Goryeosa recorded the name of the two successors of King Gongmin, as Shin U and Shin Chang, both not of the Wang Clan. Regardless of the authenticity of the excuse that they were not offspring of Gongmin but of a royal tutor Buddhist monk, Shin Don and the king's mistress.
} 
into the legal compilation. ${ }^{144}$ This is an important aspect of the Yuan law book which is yet to be fully investigated. ${ }^{145}$

The social and family relationship among Kim Ji, Jeong Do-jeon and Jo Jun suggests that late Goryeo classicists and legislators were as conscious of the effective combination of ritualism as legitimacy, and legality as power, as much as they were of formal institutions. Kim Ji was known "to be good at law" and he studied at Yeo Taek Jae 麗澤齋, one of the seven disciplinary colleges at the National Confucian Academy where the Book of Changes was taught. As Kim In-Ho suggests, his scholarship and knowledge of law must have developed along with his learning of the Classics of ancient institutions. ${ }^{146}$ The memoirs of Kim Ji written by Yi Saek ${ }^{147}$ and Kim Ji's contemporary, the philosopher Gwon Geun (1352-1409) revealed that Kim Ji's legal expertise was the ability most needed in his time. In his memoir, Yi Saek, the son of Yi Gok and also eminent senior Confucian scholar, portrayed Kim Ji "sitting in the middle of the ten thousand scroll hall.....your law book to the throne is as precious as gold and jade; your letter up to the pavilion as splendid as a phoenix or qilin..." It is not certain whether the ten thousand scroll hall was his private study, or a hall attached to an office, or King Chungryeol's study in the Yuan capital, Khanbaliq.

However, Kim's official career apparently did not last long, nor did it go well. Yi Saek wrote that he once lived in a humble residence without a regular position and property, but that he managed to collect several hundred books and became so proficient at writing letters and the artistic style of calligraphy (kaishu) that he was selected to be in charge of writing letters for royal use. ${ }^{148} \mathrm{Kim} \mathrm{Ji}$ and Do-jeon were successful candidates for the 1361 civil service examination, ${ }^{149}$ and the scarcity of further information in personal records does not necessarily imply that there was little communication between them. Moreover, Kim Ji's family

\footnotetext{
${ }^{144}$ In the study of Kim Ji and his Six Wings Kim In-ho interpreted the convey of the origins of the regional clans in the Six Wings from the perspective of the central government.t for taxation or draft of human power for public works of military service. Kim In-ho (2001).

${ }_{145}$ Oh, Gilsun, (2010). Gyeongsedejeonjirido-e-naoneun jimyeongui josawa 'honil gangniyeokdegukdojido' seoyeok jimyeonggwa-ui bigyo (A Study on the Place Names of the Wonkyung sedaijun Jirido and the Comparison with Westside of the Honil Gangi Yeok dae Gukdo Jido) Hanguk Gojido yeongu (Journal of Old Maps), 2 (2). 83-105.

146 Ibid. 134.

${ }^{147}$ For the direct quote, see Yi Saek, Mogeun sijip (Collected Poetry of Mogeun Yi Saek), 22, 'Commemorating Kim Ji'. HMC 4, 303-a: Kim In-ho. (2001). 141.

${ }^{148}$ Kim, In-ho. (2001). 137.

${ }^{149}$ Yi Saek's preface of the collected poetry and Jugwan yugik of Kim Ji provides an aspect of the life of Kim Ji and his scholarship. Kim, In-ho. (2001). 136.
} 
relationship with Jo Jun should be noted as well. According to his memorial epitaph composed by Gwon Geun, he married a lady from the Yi clan who was a sister of Jo Jun's wife: he was a brother-in-law relationship to Jo Jun, who worked with Jeong Do-jeon in the front of land reform after the 1388 coup. In a small pool of colleagues of 33 successful candidates for the state examination, it is likely that Jeong Do-jeon and Kim Ji knew each other and were aware of the each other's scholarship as well. Two articles in Korean by different authors discuss whether Kim was the author of Jugwan yugik and they do not entirely agree. ${ }^{150}$ They had no objection to the authenticity of the authorship of the Jugwan yugik suggested by Kim Ji, but Heo pointed out that Kim Ji was not the same person involved in the translation and publication of the Ming code in 1395. Heo's opinion is contested by Kim In-ho's work to which this study is consulting. In the introduction of the translation of the Great Ming Code, Demyeongyul jike 大明律直解 (the Great Ming Code, Directly Explicated) Kim Ji wrote that they undertook the project of the translation and publication in 1395 under royal order. ${ }^{151}$ Therefore, such a social and family relationship and their capacity as legislators are sufficient to explain their involvement in the translation of the penal laws of the Great Ming Code that has been claimed as exclusive enforcement of punishment in the new dynasty.

In view of all that has been mentioned so far, it is undeniable that the certain structure of legalization of power and authority of a dynasty or empire succeeded in serving to emphasize the legitimacy of the throne, and that to achieve this, Jeong Do-jeon could have adopted the dual structure of the Jingshi dadian as most appropriate for his task. It seems to be also true in the case of Kim Ji's Six Wings regardless of the time and object they served for. As mentioned, the entire section of Jeong's Code dealing with matters of the ruler was copied from the Jingshi dadian except for minor points related to imperial matters. Justification of the throne and, more importantly, the matter of royal succession based on the Confucian values can be regarded as issue that the authors desired most to found on constitutional arrangement when various competing forces and interests were involved in early stage of state craft. The precedence of

\footnotetext{
${ }^{150}$ Heo Heung-sik dismissed the possibility that the author of the translation of the Great Ming Code was Kim Ji because Kim Ji, as a follower of Yi Saek who was not on behalf of Yi Seong-gye in the late Goryeo period would not have had the opportunity to be involved in such an official project. Kim In-ho, based on Kim Ji's familial and social relationship with Jo Jun and Jeong Do-jeon, and his well-known scholarship, suggested that Kim Ji was one of the co-translators of the translation of the Great Ming Code and he was the same person who had written the Jugwan yugik. For the political status of Yi Saek in the late Goryeo see Lee, Ik-Joo. (2008). Goryeo uwangde isekui jeongchijeok wisange dehan yeon-gu (A Study of Lee Saek's political status in late Koryo). Yoksa wa hyonsil: Quarterly Review of Korean History, 155-187.

${ }^{151}$ It was suggested that the Korean translation of the Ming Code was the 1389 version. The Great Ming Code/ Da Ming Lu, translated by Jiang Yonglin, Seattle: University of Washington Press.
} 
royal matters to the administration in the Code is itself a manifestation of hierarchical order of power. At the same time by incorporating the power of ministership into canon system as well, Jeong intended to insure the claim of the literati class to positions of power in the order as a legal institution, the topic to which we now turn.

\section{3-3. Kingship and Ministership}

What has become popular in academia in interpreting the political thought of Jeong Dojeon in his 1394 Code is its power separation scheme - the balance between kingship and prime ministership. This section contests that Han's interpretation is a result of lack of balance regarding time and emphasis in the formula of Jeong's trilogy, meaning the Code, and his two subsequent works of Gyeongjemungam 經濟文鑑 (Literary Mirror of Governance) Gyeongje mungam byeoljp 經濟文鑑別集 (Supplementary of the Literary Mirror of Governance). Jeong certainly did not show blind obedience to royalty and did advocate for the role of the prime minister as regulator in the bureaucracy. In the general principle of the 'Personnel', the first legal corpus of the second part of the Code dealing with "matters of administration" the qualification of the prime minister and his relationship with the king is explained as follows:

The quality of individual rulers is varied: there are those who are wise; those who are dull; those who are strong; and those who are weak. Therefore, it is the job of the Prime Minister to respect the goodness of the ruler; to correct the faults of the ruler; to revere the decisions of the ruler so that they are well performed; and to prevent improper royal orders from being performed so as to lead the throne to attain the state of the great balance [in state affairs]. Therefore the role [of the prime minister] is called xiang (相) which means to 'complement'. 152

The personality of the ruler, as Jeong Do-jeon wrote, can vary, so does the quality of policy that are decided by the monarch. Therefore, it is necessary for the virtue of the Prime Minister to guide the ruler towards the right path or to correct a wrongful mind. The Prime Minster, then, is expected to be sufficiently wise and virtuous to act as an assistant to the king. Otherwise, he could not help the ruler to rectify his moral failure to practice of power for the well-being of people. In order to realize the principal values of governance of 'benevolence'

${ }^{152} S B$ 7:5a. 
and 'people as foundation' (minben 民本) as quoted from the Mencius, royal decisions on the policy-making process should be made with the support of cultured men. Ironically, therefore, the significance of the role of prime minister as the regulator of the administration was extended to that of a tutor to the ruler who was the only person able to influence the king to stay on the tightrope of moral self-cultivation. This type of Confucian moral politics has become extremely popular for academic research in the genre of Confucian constitutionalism, as it forms part of an integrated law mechanism. Hahm Chae-hak ${ }^{153}$ illustrates how unwritten institutions such as conventions, customs, and codes of conduct in a society strengthened the polity as institutional enforcement during the middle of the Joseon period. The work of B.N. Son ${ }^{154}$ provides a useful framework in that the classical Confucian norms espoused by Confucius, Mencius, and Xunzi, could basically be informal institutional constraints on human behaviour. Although Han Young-woo did not engage with such terms of 'Confucian constitutionalism', he still argued that the nature of the throne as maintained by Jeong Do-jeon was to make the throne step back as a 'symbolic authority' in constitutional arrangement of power. ${ }^{155}$

The confidence of Confucian intellectuals to be the moral guide for a ruler demonstrated by Jeong Do-jeon had a long history in East Asia. The precise analysis by Wood of the dilemma as Song thinkers faced when dealing with such ideas in the twelfth century is helpful to understand their applications on fourteenth century Joseon Korean politics. As Wood has articulated in his well-rounded work, the birth of metaphysical speculations of Song Confucians over the expansion of law of nature into worldly order was the child of chaotic political circumstances. The insecure national defence of Song society from the threat of invasion from barbarian peoples, the Khitan Liao, in the northeast and the Tangut Xi-Xia in the northwest stimulated a crisis of cultural and state identity. When the Northern Song was finally humiliated in 1127 by the nomadic Jurchen, Song intellectuals were inclined to a strong centralized state in a policy of 'revering the emperor and expelling the barbarians'. However, the policy was not merely a repetition of old phrases but, as Wood explained, the period of disorder inspired a fundamental re-examination of conventional political philosophy. Song Confucians created a new frame of reference for Chinese political thought to seek the most appropriate formula for the authority of the emperor: strong enough to ensure the certainty of

\footnotetext{
${ }^{153}$ Hahm, Chai-hark. (2009). Ritual and Constitutionalism: disputing the Ruler's Legitimacy in a Confucian Polity. The American Journal of Comparative Law, 57, 135-203.

${ }^{154}$ Son, B.N. (2012). Confucian Constitutionalism: Classical Foundations, Australian Journal of Legal Philosophy, 37, 61-98.

${ }^{155}$ Han. (1999). 172.
} 
state and at the same time not so strong that it diminished the civil order. What they turned to in endeavouring to deal with the dilemma was the perspective of history of the Spring and Autumn Annals (Chunqiu), a chronicle of events covering the period from 722 to $479 \mathrm{BC}$ and considered to have been compiled by Confucius himself. The traditional norm of the Mandate of Heaven, as a result, was transformed into the ultimate end to be served even by the ruler of humanly world, also indirectly serving to restrain the arbitrary exercise of imperial power to prevent the repudiation of civil order. The importance of the agents of civil government, therefore, would go parallel with the legitimacy of the ruler in way that the responsibility for ensuring the ruler would not stray from the right path (dao) rested on the shoulders of the scholar-elite. From where, then, does the legitimacy of the ruler come? It comes from adherence to the order of ritual propriety $(l i)$, the materialized form of the Mandate of Heaven in the secular world, and it was the literati who helped the ruler to fully understand and interpret the moral order hidden in natural phenomena. ${ }^{156}$

The principle of moral politics sketched in the 'Personnel' (chijeon 治典), the first section of the administration the Code found its support from Jeong's supplementary work Gyeongje mungam (Literary Mirror of Governance). As a criticism of grand councillors in Chinese history, it adopted the perspective of Chun qiu, continuous self-cultivation as a quintessential requirement of prime ministers. The entry of exemplary Grand Councillors (Jesang 宰相) in this work, is full of confidence of Jeong Do-jeon in the literati class as the sole agents of the Mandate of Heaven between the ruler and the ruled: the prime minister would be in charge of bureaucratic appointments, military affairs in central and regional districts, management of state revenue, rewards and punishments, and even the royal exchequer. Yet the significance of the prime minister as the regulator of government was not limited to worldly matters. The cosmic balance of yin 陰 and yang 陽 also relied on whether the prime minister was a qualified wise man deserving the position. Therefore, strict rules were required for the candidates for the prime ministership; they needed to rectify themselves first, then rectify the ruler, officiate the proper men and then manage state affairs with impartiality.

The essential requirement of the prime minister in the Code can be undoubtedly ascribed to the legacy of Song thinkers, in particular Zhen Dexue (1178-1235) and Zhu Xi (1130-1120). The reference of Jeong Do-jeon to the words of Zhen's commentary of the Daxue

156 Wood. (1999). 15-16. 
(Great Learning), Daxue yanyi 大學衍義, has persuaded many historians to decode the implication of the Code as an informal institutional imposition on the power of the ruler, or in other words constitutionalism. In terms of symbolistic authority, it is naturally reminiscent of neo-Confucian $l i$ qi 理氣 metaphysics, in which kingship is pushed into the realm of the universal principle $l i$ (理), while the ministership is charge of the realm of human affairs ( $q i)$. However, the understanding of $l i$ qi metaphysics in the Code is limited, as seen in the Right Throne. The proclamation of legitimate kingship occurs mainly through consulting traditional Confucian thoughts from the Book of Changes and the Book of Documents (Shu Jing), what is most emphasised by Jeong Do-jeon is 'benevolence' (仁)., Instead of articulating the metaphysical frame, Jeong jumped to the diversity of things and the virtue of Heaven, saying that, "Although things exist with diversity of their own material forms endowed by energy ( $q i$ 氣) and function, the virtue of heaven is to care and grow things that exist.” Instead of further mention of $q i$ from li qi (理氣) rhetoric he connects the authority of the ruler with the value of benevolence. The evidence that Jeong Do-jeon attributed the source of universal basis for the authority to the liqi theory in the Code is poor. Rather his adherence to classical values for evaluating the well-being of people seems to be predominant; he concluded the section by saying that, "No matter how much treasure the ruler possessed or how magnificent his authority was, it would be the people that decide the destiny of the king's rule."157

Another works of Jeong Do-jeon, Gyeongje mungam byeoljip (Supplementary Work of the Literary Mirror of Governance) dealing with the dao of kingly governance, presumably compiled in 1397, is open to another interpretation that supports the argument of this study. While the Literary Mirror of Governance provides a detailed description of the roles and specialization of each government office according to the Zhouli, the Gyeongje mungam byeoljip is a historical review of rulers of the dynasties of China and Goryeo under one heading, the dao of the ruler. Jeong Do-jeon demonstrated that the ideal polity to model on was the time of three legendary emperors, Yao (traditional dates c. 2356 - 2255 BC), Shun (traditional dates 2233 BC-2184 BC) and Yu (traditional dates 2205- 2198 BC) of the Tang, Yu and Xia dynasties, respectively. ${ }^{158}$ The chronology of the ideal rulers of China was then followed by that of Goryeo monarchs with a short review of their personalities and judgements of their policies in regard with how much they realised the traditional Confucian norm. The 'supremacy

157 SB 7:5a.

${ }^{158} S B$ 5:2a-b. 
of the throne' was repeatedly emphasised which may appear to contradict with the significance of the role of the prime minister as suggested in the Gyeongje mungam.

While Han Young-woo's opinion between the kingship and prime-ministership is founded on the 'idealism' presented in the Mirror of Governance, Song Jae-hyeok has narrowed the role of prime minister as a royal assistant in a dynastic rule in which no one can be above the ruler in the hierarchy. As expected, Song puts more weight in the ideas of kingly governance of the 1397 supplement to the Mirror of Governance than on the primeministership of the 1395 Gyeongje mungam. He also saw the need for strong kingship of Joseon Korea distinct from the contemporary absolute imperial power of the Ming. On the surface it seems that Joseon placed itself as a subservient power to the Ming, as evidenced by the organization of official robes and grades system being three degrees lower than those of the Ming court. This is evident in other aspects of the Zhouli structure by which the world should be organized in hierarchical order. ${ }^{159}$ For Jeong Do-jeon, ritual propriety (li) was nothing less than 'order' by which hierarchical order could be conducted in the world, both domestically and internationally. He then simply added in the corpus of the Rites, yejeon 禮典, that the ruler is to be highly revered, and subjects humble; the ruler orders and subjects obey. ${ }^{160}$ The $l$, Song suggested, was a realization of institutionalized political hierarchy in which the throne should be unquestionably respected. Therefore, the role of prime minister should be the medium between ruler and bureaucracy to ensure that the royal will is implemented.

An example of an attempt of balancing the emphasis on kingship and ministership can be found in Wang Anshi (王安石 1021-1186), the Grand Councillor of Song dynasty. Wang, who had pursued bold new policies that were strongly resisted by conservative officials, viewed his relationship with the emperor as a hierarchical partnership:

"of the matters of great importance, ...the king and the Grand Councillor should both be in charge; of the matters of lesser importance,...only the Councillor should be in

\footnotetext{
${ }^{159}$ Song, Jae-Hyeok (2016). Jeongdojeonui gunjuron-gyeongjemungambyeoljipeul jungsimeuro (A Study of the Confucian Kingship Theory of Jeong Do-jeon-focused on Kyeongjemungambyeoljip). Jeongchi sasang yeongu (The Korean Review of Political Thought), 22, 75-98.

$160 S B$ 7:25a.
} 
charge; of the matters of the eight levers and eight commands,...only the king should be in charge, and the Grand Councillor should only report the truth."161

What could be the reason of Wang for maintaining the partnership? Wood discusses the mechanism of power formula suggested by Wang Anshi, which bears resemblance to what Jeong Do-jeon suggested and argues that the legitimacy of the authority of the ruler and the power of the civil agents of the government should not necessarily be interpreted as antagonistic counterparts competing to occupy more beneficial positions in the political decisions at the court. ${ }^{162}$ These changes that Wood identified set the stage for a partial stimulus for the rise of neo-Confucianism and he took the examples of circumstances powerful grand councillors whose power always tended to increase when the emperor was personally weak or uninterested in state affairs, and he concluded, this was the case during much of the Song dynasty. The early implementation of centralizing institutional changes still left potential for autocratic power to be exercised when conditions changed. Once the equilibrium was broken it is likely that those opposing the ruler would perish; and there were various factors to be contemplated in addition to the two categories of king and prime minister in the power formula of both mediaeval China and Goryeo. Among them the military, aristocrats, and Confucian literati with less inherent advantages, as well as the degree of social differentiation of Goryeo society that would have affected in determining the degree of strength of each activator of power formula. Collaboration of these elements to expand their own power, as seen in the corporation of a literati Jeong Do-jeon and a military hero Yi Seong-gye, adds even more to application of power formation. This leads again to questioning Han Young-woo's one-sided view on Jeong's ideas of prime ministership. This is not to argue that Jeong Do-jeon insisted on less portion of power than traditional grand councillors could have enjoyed but instead, what he did is comparable to Wood's description of Song thinkers' employment of ideas as an institutional base to ensure the power of the literati class by equipping themselves with 'ideological claims to political power that the military and the old aristocracy could not possibly have matched', as an institutional base to ensure their power. ${ }^{163}$

\footnotetext{
${ }^{161}$ Song, Jaeyoon. (2009). The Zhou Li and Constitutionalism: A Southern Song Political Theory. Journal of Chinese Philosophy, 36, 424-438.

162 Wood. (1999). 146-147.

${ }^{163}$ Ibid.
} 
As seen at the end of Goryeo dynasty, the traditional ideas of legitimacy utilized for the removal of incumbent authority were again only the source to seek for the legitimacy of new authority. It is from this perspective the core of the Code can be better understood. What is innovative in the Code, then, is that cultural norms of the legitimacy of the throne were integrated into a legal institution, the compendium of laws, in which the authority of the ruler took precedence over the administration in charge of the prime minister. However, this did not mean absolute obedience to the ruler. The tradition of the Zhouli was also expected to ensure ministership as regulators in the government. Beneath the structural preference of the Code lies an attempt to restore civil order for the new dynasty modelled on the punitive laws of the Tang and the government system of the Song in the same way this was believed to have been done during the reign of Seongjong of Goryeo in the $11^{\text {th }}$ century. These two models were at the same time credited for loyalty to the ancient system of the Zhouli, the law and culture of the sage kings and emperors, to which the Korean classicist Jeong Do-jeon committed in order to realize in the society he lived.

The central concept of the Code is order, which governs things that exist hierarchically. The structure of the Code is therefore a codification of legitimacy into legality in a condition that legitimates power taking precedence over administration and does not permit any disturbance of the authority of the throne. Justification of the throne as the head of state is the priority of the Code; schemes for the separation of powers are relatively unimportant. 


\section{CHAPTER FOUR}

\section{REVITALIZATION OF CIVIL ORDER}

The Chapter deals with another importance of the Code- the continuity of the institutions in Joseon from the previous dynasty, Goryeo. As seen in the previous chapter, it was nothing but the 'order' in a hierarchy that was articulated by Jeong Do-jeon as being the core element of the security of the society and the world. The following chapter argues that the revitalization of the past Tang and Song systems in the Code was considered as the institutional means to realize civil order. Three factors are discussed as the stimulus for Jeong Do-jeon to resolve the institutional difficulties that the late Goryeo faced, and the status of the Code is conclusively examined as more a political manifesto declaring the return to the prior system than has been interpreted as modular law corpus.

\section{4-1. The Zhouli 周禮: The Ancient Institutions, guzhi 古制}

As Jeong Do-jeon stated at the end of the article about the State Name, his dream was "to transform the state into Zhou itself in the East." Jeong believed that architecture of dynastic institutions should be undertaken according to institutions of Zhouli. Adherence to the Zhouli is illustrated in the nomenclature of the six law corpora of the Code that exactly correspond to those of the six offices of the Zhou dynasty: Personnel to the Office of Heaven, Revenue to the Office of Earth, Rites to the Office of Spring, War to the Office of Summer, Justice to the Office of Autumn, and Public Works to the Office of Winter. In the Code Jeong quotes nine entries from the Zhouli: two in the section on Personnel ${ }^{164}$; two in Revenue ${ }^{165}$; one in Rites ${ }^{166}$; and four in War. ${ }^{167}$ The articles in which Jeong Do-jeon provided quotations from the Zhouli are rather general principles such as employment of talented young men, having three supreme ministers as assistant staff of the court, and emphasis on the importance of agriculture, military training and regular checks of weapons. As we shall see later, Jeong's specific concern shown through the quotations he used seems to rearrange the society in accord with the agrarian

\footnotetext{
${ }^{164} S B$ 7:5a

165 SB 7:4b, 7:20b.

${ }^{166} S B$ 7:31a.

${ }^{167} S B$ 8:1a, 1b, 2a, 3b, 8a.
} 
economy in which the social status of four classes would fit respective economic activities and the literati class serve would function as civil agents mediating the Mandate of Heaven and the human world.

Consulting the Zhouli for models by which societal advance could be promoted had a long history in Korea. Since early Korean kingdoms had been in competition to establish their state institutions by importing and implementing Chinese various institutional measures on their soil. Although the founder of Goryeo, who had been no more than a regional lord, did not ignore Buddhist ideology as the base of his power, his successors imposed Chinese institutional systems in order to bring about centralized bureaucracy and to shape society into a more organized form. As knowledge of Chinese classics and literary scholarship had become indispensable, so the officiation of literati for civil matters resulted in an early form of meritocracy. The adherence to the Confucian classics then fostered state institutions and the candidates for civil matters by the introduction of civil service examination. Thanks to the influx of other Chinese institutions, i.e., penal laws, administrative organizations, and official robes and rituals, Goryeo government offices could be structured with a certain degree of substantial specialization and differentiation of political roles. As seen in the memorials by Choi Seung-no (917-989) to the king Seongjong (r. 987-997) suggesting that Buddhism remain as a private religious activity, the zeal of Confucian civil officials to be the agents of governance often came to the surface in court politics. ${ }^{168}$

Zhouli was first referred to by a Goryeo official as a ritual manual during the reign of King Seongjong. According to the History of Goryeo, Yi Yang (李陽), a civil official, advanced a memorial to King Seongjong in 988 asking that the Queen perform a ritualistic ceremony of preparing seeds for the altar in accordance with the Zhouli. ${ }^{169}$ The increase of the significance of the Zhouli as the canon of state institutions in Goryeo, however, did not happen suddenly; it had gradually expanded its importance along with the rise of Confucian bureaucrats and development of central bureaucracy since early Goryeo times. The change is represented in the change in subject matter of the section of on ritual propriety $l i$ (Ye-ji 禮志) in the Goryeosa, a chronology which shifts from being a manual of royal ceremony and ritual for relations with

\footnotetext{
${ }^{168}$ In Choi's essay of twenty-eight policies presented to the sixth ruler of Goryeo, King Seongjong, he warned of the evils of Buddhist conventions and the administrative abuses of local strongmen, both of which were endemic in the late Goryeo period.

${ }^{169} G S, 3$, sega, article of the 25 th day of the second month of 988 ( $7^{\text {th }}$ year of reign of King Seongjong). Retrieved from kr_003r_0090_0010_0010.
} 
neighbouring countries to describing government institutions. Then, the Zhouli, in essence a text concerned with administrative structure, has been one of the most significant Confucian texts for navigating state institutions in Korea until the end of the $19^{\text {th }}$ century. As the change in the importance and practice of the Zhouli among Confucian classics in China and Korea is closely related with rise of self-confident scholar-robed Confucians, a brief examination of the historical development of the Zhouli is helpful.

As many researchers have suggested, the Zhouli with no argument for a Confucian legitimacy of the power of the ruler is rather closer to legalistic thoughts of maintaining the order of society. Although its philosophy is linked with other sources such as the Book of Rites Liji 禮記, a Confucian classic containing manuals of ritual, ${ }^{170}$ political interest in it seems to begun from religious motivation. As Confucianism can be described as "a loose set of doctrines derived from the teachings of Confucius", ${ }^{171}$ it composed of knowledge of Chinese classics and literary scholarship, was indispensable in the management of government affairs. ${ }^{172}$ The chemical reaction of a metaphysical linkage between The Mandate of Heaven and its manifestation in governance of the Zhouli was instigated by the Confucian thinker Dong Zongshu (董仲舒 179-104 BC), speculating that heavenly intervention in the form of natural portents prevented the ruler from straying too far from the path of righteousness and responsibility for the well-being of the people. ${ }^{173}$ This is an early adaptation of the Zhouli in moral politics. The Zhouli which purports to describe the administrative structure of the Western Zhou dynasty (ca. 1050-771 BC) was central to academic discourses and had enduring influence on state institutions in the history of East Asia. For the composition of the Zhouli, one of thirteen Confucian Classics, it is now agreed that the text, unlike the Confucian narrative

\footnotetext{
${ }^{170}$ Puett, Michael. (2010). Centering the Realm: Wang Mang, the Zhouli, and Early Chinese Statecraft. Statecraft and Classical Learning: The Rituals of Zhou in East Asian History, 132-154.

${ }^{171}$ Brook, Timothy. (2012). The Troubled Empire. Massachusetts: The Belknap Press of Harvard University Press. 162.

${ }^{172}$ Chan, J. (2014). Confucian Perfectionism: A Political Philosophy for Modern Times. Chan makes it clear in the introduction of his thesis that he intends 'to explore the implications of a traditional political philosophy for a number of fundamental issues of modern politics.' But to explore the implication, he looked into the philosophical layers of Confucianism in dealing with the norms of ethics, morality and social justice. The matter of how the ideal ends employed by Confucian thinkers were to be fulfilled in reality was also an important question for the Goryeo and Joseon Confucians up until modern time. For them to reconcile the ideal end and cultural peculiarity was an ever-lasting project.

${ }^{173}$ Scholars agree that Dong Zongshu was the founder of Han Confucianism as an imperial philosophy and political thought of governance based on cosmology. Tung's ideas had a huge influence on the development of Confucianism as an ideology after his death. For his biography and overview of his thoughts see, Queen, Sarah A. (1996). From Chronicle to Canon: The Hermeneutics of the Spring and Autumn Annals According to Tung Chung-shu, Cambridge: Cambridge University Press. 13-67.
} 
of its origin from the Western Zhou dynasty, had actually been circulated later during the Warring States Period in China (BC 403-BC 221). It was then compiled around the fall of Han dynasty (AD 8), with the current name changed from the original title, Zhouguan.

The adherence to the Zhouli as means of institution was begun by the usurper Wang Mang (45 BC-23) of the short-lived Xin dynasty (8-23 AD) of China. He adopted the Zhouli ${ }^{174}$ in order to bring change into state institutions, i.e., ritual, taxation and administration offices. 175 With the downfall of Wang Mang, however, the Zhouli was expunged from the state academy and its resurrection had to wait until the appearance of an ambitious young statesman of Song China, Wang Anshi. ${ }^{176}$ As advocator of the New Policies during the reign of Xinzong (r. 1067-1085), Wang Anshi undertook an overall reform of Song society - finance, the military and agriculture and even the transportation of goods system. He consulted the Zhouli for statecraft, regarding its principles of governance as fundamental to reform. In fact, it has been argued that the reason for the adoption of the Zhouli was not because the ideology embedded in it befitted the contents of Wang Anshi's reforms, but because the Zhouli had been established as the source of legitimacy for the authority of ruling. ${ }^{177}$ Therefore, even those parties opposing the New Policies utilized the Zhouli to support their opinions. Wang himself composed a commentary book on the Zhouli, the Zhouli Xinyi 周官新議 (New Explanation of the Zhou Offices), which Jeong Do-jeon consulted for the political structure of new Joseon dynasty. Wang's interpretation of the 'old system' for the new institution of the Song was one of the sources of Jeong's Supplement to the Code, in particular the section of the role of prime minister. ${ }^{178}$

The debt that Goryeo literati owed to the Song thinkers on neo-Confucian perspectives of the political system seems to be far more than the influence of certain concepts. Goryeo elites presented strong belief in their Song correspondence and attempted to internalize these

\footnotetext{
${ }^{174}$ For the matter of the compiler of the Zhouli there are various opinions. Among them is Xu Fuguan (19041982) in his Zhouguan chengli zhi shidai ji qi sixiangxingge 周官成立之時代及其思想性格(1980) in which it is suggested that Zhouguan was begun by Wang Mang but completed in its final form by his councillor, Liu XinYou.

${ }^{175}$ Paper by Song Jaeyoon in the Statecraft and Classical Learning: The Rituals of Zhou in East Asian History edited by Benjamin A. Elman and Martin Kern, Brill, 2009, 424-438.

${ }^{176}$ For a basic question why a text like Zhouli was employed by Wang Mang and, later, Wang Anshi see Michael Puett, Centering the Realm: Wang Mang, The Zhouli, and Early Chinese State Craft, Statecraft and Classical Learning: The Rituals of Zhou in East Asian History edited by Benjamin A. Elman and Martin Kern, Brill, 2009. 129-154.

177 Wood (1999).

178 Kim, In-ho. (1999). 64.
} 
intellectual developments. Since the end of the tenth century, Song China was for Goryeo intellectuals the most culturally advanced country from which state institutions were to be imported. Beyond a trading partnership, intellectual ideas of governance and law enforcement from the Song dynasty exhorted great influence on Goryeo. Surviving documents reveal how eager Goryeo kings and the ruling elites acquired history books to consult them as references for institutional innovation. The description of an occasion of one Goryeo ruler illustrates well this phenomenon. The Goryeo official, Kim In-jon (金仁存 died circa. 1127), stated in the Record of the Royal Lecture Hall (kr. cheongyeongakgi) that,

The king had built two royal lecture halls in which he put the collection of edicts, writings and paintings of Song emperors and used to enjoy discussions with Confucian worthies and scholars. [...] It was full of the vigorous spirits of 'three principles and five virtues' (chi. sanggang wuchang) and the universal principle ( $l i$ 理) of life morality (chi. Xingming 性命). ${ }^{179}$

It was not until the Yuan control of Goryeo that the implementation of Song neoConfucian concepts of politics was ideological driver for the change in state institutions and the political activities and the conduct of the ruler. The introduction and development of neoConfucianism in Goryeo was marked by ambivalent attitudes at first: when the Mongol Yuan gradually metamorphosed itself into the imperial order by the infusion of Chinese traditional institution, Goryeo monarchs and elite groups articulated their cultural orientation of 'Little China' with territorial statehood inherited from Gija, as previously discussed. ${ }^{180}$ The reorganization of Goryeo polity under the Yuan empire was described in Goryeo History as being a 'forceful and profound' change by the Yuan power, but at the same time Goryeo intellectuals had also opportunity to reorganize their position as policy makers and partners of the ruler in governance as the Yuan renovated education and the civil service examination system. Through the introduction of Zhu Xi's neo-Confucianism by the Yuan as new curriculum for national Confucian academy and the textbook for state examination, the confidence of young Confucians were nurtured as a literati class on which the rectification of the ruler was

\footnotetext{
${ }^{179}$ Dongmunseon (Selection of the Writings of the East), 64, Cheongyeongakgi (Record of the Hall, Cheongyeongak): Yi, Won-myeong. (2000). Goryeochogi seongnihak ihegwajeong yeon-gu (A Study of the neo-Confucianism in the Late Goryeo and the Early Joseon). Guksagwan nonchong (Journal of Korean Studies), 92, 263.

${ }^{180}$ Do, Hyun-chul. (2000). Wonmyeong gyochegi goryeo sadebu-ui sojunghwa uisik (The Koryo Sadaebu's Conciousness of "Little-China" During the Period of Dynasty Change from Yuan to Ming). Yŏksa Wa Hyŏnsil: Quarterly Review of Korean History, 37, 119.
} 
dependent. The practice of family rituals according to Zhu Xi's manual of family rituals, Zhuzi jiali 朱子家禮 became their cultural badge. ${ }^{181}$ The Buddhist or Daoist rites were regarded as 'evil teaching' in the daotong (the Transmission of Truth) and needed to be replaced. In the front was Yi Je-hyeon, as mentioned previously, the most significant official servant to several successive Goryeo kings. He came from a scholarly family and married a daughter of Gwon Bo (1262-1346) who was also an eminent Confucian-scholar and who reportedly introduced the Chinese classics of The Four Books with Zhu Xi's commentaries (chi. Sishu jizhu) to the Goryeo intellectual community. Gwon Bo had also been involved in compiling a catalogue with Yi Je-hyeon's father, Yi Jin, of the collection of Confucian learning materials sent from the former imperial library of the Song dynasty by the Mongol ruler to the Goryeo capital in 1314 in response to Goryeo intellectuals' demand for books. Along with the introduction of the Four books and Five Classics with annotations by Zhu Xi also came the change in the text for the education of kings. The Zhenguan Zhengyao 貞觀政要 (Essentials about politics from the Zhenguan reign (627-649) had been the most favoured text in Goryeo for the education of a ruler the until the mid of fourteenth century. Yi Je-hyeon saw the need for self-cultivation of the ruler as a prerequisite of kingly governance and in his petition to King Chungmok (r.1344$1348)^{182}$ before King Gongmin, Yi advised the young ruler to read The Four Books to 'study the underlying principle to acquire knowledge' (gewuzhizhi 格物致知) and to 'build sincerity and rectify the mind' (chengyi zhengxin 誠意正心). Another favoured text among Confucian scholars for kingly cultivation was Daxue Yanyi (Extended Meaning of Great Learning) written by the Song Neo-Confucian, Zhen Dexiu (1178-1235). This text had a great influence on Jeong Do-jeon, not only did he directly refer to it in his Code, but he also copied four parts out of eleven parts of Zhen's work for his critical essay against Buddhism, Bulssi japbyeon 佛氏雜辨 (Miscellaneous Excuses of the Buddhists).

What were the concrete results of the neo-Confucian ideology for the model government of Goryeo society? Regarding state institutions, Goryeo Confucian officials took the examples of punishment law of Tang (唐 618-907) and the government structure of Song (宋 960-1279) of China as the well-balanced institutions to implement in their society. This is

\footnotetext{
${ }^{181}$ Do, Hyeun-chul. (2005). Goryeomal yunsojongui hyeonsil insikgwa jeongchi hwaldong (Yun So-jong's perspective of and involvement in politics in the late Goryeo). Dongbanghakji (Journal of Yunsei institute of Korean Studies). 1-35.

${ }^{182}$ Zhenguan Zhengyao is a compendium on statecraft from the reign of Emperor Taizong 唐太宗 (r. 626-649) of the Tang dynasty (618-907), compiled by Wu Jing 吳競 (580-643).
} 
well illustrated in the statement 'fatang tisong 法唐體宋' 183 of Yi Gok (1298-1351), a scholarofficial and Jeong Do-jeon's tutor. Therefore, when there arose a sense of crisis of institutions, in particular when legal enforcement by the Yuan in Goryeo increased around 1350s, there arose calls for restoration of the government system that had been carried out during the reigns of Seongjong and Munjong (文宗 r. 1046-1083) of Goryeo when late Goryeo scholar-officials believed to have achieved ideal civil-order by following the Tang and Song. ${ }^{184}$

Then what could be the reason for the drive for political reform in the late Goryeo? According to Wood, 'political thought is the child of chaos and the father of order' ${ }^{185}$ The causes of the crisis of the fourteenth century of Korean society that Goryeo elite diagnosed can be categorized into three factors: 1) uncertainty over the institution of kingship; 2) legal discrepancies; 3) collapse of the economic system, i.e., land and taxation on all of which the livelihood of the literati depended to some degree. In a society where an individual's social status determined economic circumstance, law-making and enforcement falls into the hands of the privileged. ${ }^{186}$ In a Confucian hierarchical society composed of four classes with literati at the apex, legal institutions had to be controlled by the literati class. All these factors have been cited by modern scholars as reasons for the end of the Goryeo dynasty, ${ }^{187}$ yet how these were reflected in the contents of the Code has been given less attention. The restoration of civil order to resolve these problems is also associated with the interests of the literati class who wished to occupy the top position in society as mediators between the ruler and the ruled. The pursuit of civil order is apparently revealed in the second part of the Code. Therefore, it is proposed that the Code was composed with a political mission rather than as legislation.

\section{4-2. Law from the Tang; System from the Song}

Institutions from the Song are revived in the legal corpus of the 'Personnel' in Jeong Do-jeon's Code. Although Jeong Do-jeon simply described five upper bodies and six

\footnotetext{
${ }^{183}$ Kim, Sung-kyu. (2014). Goryeo oigyo-eseo uiryewa gukwangui jase (Ritual ceremonies, including the King's posture, reflecting Goryeo diplomacy). Yoksawa hyonsil (Quarterly Review of Korean History), 94, 363-394. ${ }^{184}$ For the introduction of Tang and Song institutions and modification of them, see Byeon, Tae-seop (1971): Pak, Jae-U. (2012). Goryeojeongi jeongchi jedo-ui wunyeonggwa dangsongje (The Administration and the introduction of Tang and Song systems to Goryeo), Yeongsawa hyeonsil 86, 15-32. 185 Wood. (1995). 265.

186 Peake, Cyrus H. (1937). Recent Studies on Chinese Law, Political Science Quarterly, 52, 117-138.

${ }^{187}$ Yi Ik-ju, Do Hyeon-chul, Han Young-woo, Kim In-ho. Kim Seok-geun.
} 
ministries, the continuity of roles and specialization was inherited from the early Goryeo system. The Chancellery, Munhabu 門下部, was to be responsible for the discussion of matters of the state to assist the ruler; the State Finance Commission, Samsa 三司 for revenue; Bureau of Military Affairs 中樞院 for the military; Academicians, Chunchugwan 春秋館 and Yemungwan 藝文館 for scholastic affairs; and the Office of Censors, Saheonbu 司憲府, for surveillance. ${ }^{188}$ As mentioned above, there are three reasons for the institutional difficulties of the late Goryeo that have often been pointed out in the recorded discussions among Goryeo civil officials. The revival of Song government system in the Code was not a change of nomenclature of government offices, but actually entailed the restoration of Goryeo civil order. More specifically, in the time of reform, the restoration of Goryeo institutions completed during the reigns of Seongjong and Munjong was called 'constitution of royal ancestry [of Goryeo]', jojong jiheon 祖宗之憲 (chi. zuzong zhixian).

The constitution of royal ancestry was it that was not allowed to change and so that the loadstar for the Goryeo legislators would not get lost. It was the product of the endeavours in grappling for the centralization of power around the kingship. Since the beginning of the Goryeo dynasty the first king was aware of the fragility of the kingship in opposition to military and local gentry. Based on the increase of numbers of royal relatives through marriage alliances with local lords and patronage of the Buddhist monasteries implemented by Goryeo's progenitor, one of his sons Gwangjong (光宗 r. 949-975) achieved primacy of royal power in the central government through more articulated institutionalization. First, to add prestige of his authority Gwangjong claimed the title of 'Emperor', called the capital an 'Imperial City', and created a large military force directly under his own command. ${ }^{189}$ This was followed by a series of reforms such as the Slave Investiture Act, civil service examination ${ }^{190}$ and the establishment of official robes. By the 958 decree of adoption of the Chinese civil service examination, those who were able to prove their Chinese literacy officiated civil and military matters. ${ }^{191}$ Subsequently, economic basis for bureaucrats was instituted by Gwangjong's successor, Gyeongjong (r. 975-981) in 976, by which government officials were provided tax

\footnotetext{
${ }^{188}$ Han (1999). 50

${ }^{189}$ Kim, Nak-jin. (2017). Goryeo gwangjongui siwigun jeungganggwa gunjegepyeon (Strengthening the Siwigun (the Royal Guard) and Reforming the Military Organization during the Gwangjong Reign of the Goryeo Dynasty). Daegu sahak (History Journal of Great Confucius), 127, 117-156.

${ }^{190}$ Yi, Seong-mu. (1994). Hangukui gwageo jedo (Civil Service Examination of Korea), revised edition.

${ }^{191}$ For early Goryeo institutionalization see Chapter One of Duncan (2000).
} 
receipts from land allocated to them. It was then King Seongjong (r. 981-997) who reorganized the early central institutions in 983 into the Tang dynasty's three department-six ministry system, ${ }^{192}$ which brought with minor modification a degree of specialization and differentiation of officialdom during the reign of King Munjong (r. 1046-1083). In the composition of central government the three departments were executive bodies composed of the Secretariat which was responsible for drafting policy, the Chancellery for reviewing policy, and the Executive which was charged with implementing policy through its subordinate ministries: Personnel, War, Revenue, Rites, Punishments, and Public works. As it turned out, the new system underwent modification ${ }^{193}$; the Secretariat and the Chancellery formed a combined entity, the Secretariat-Chancellery, under the leadership of the junior first-grade Supreme Chancellor, the highest ranking official in the government. ${ }^{194}$ The six ministries were directly subordinated to the Secretariat-Chancellery, whose first- and second-grade officials, jaesin 宰臣 (chi. zaichen), held concurrent appointments as supervisory directors of the six ministries as well as other key organs such as the finance commission and the Hallim 翰林 (chi. Hanlin) academy as shown in Figs.2 and 3. Since Seongjong's reign, the Chancellery had formed a combined entity, the Secretariat-Chancellery, under the leadership of the junior first-grade supreme chancellor, the highest ranking official in the government that can also be rendered as the 'prime minister'. The six ministries were directly subordinated to the Secretariat-Chancellery, whose first-and second grade officials held concurrent appointments as supervisory directors of the six ministries. Other key organs such as the finance commission and the Hallim academy were under the scrutiny of the upper echelon in the government.

Another center of power in the government was the Bureau of the Military responsible for war. Five junior second-grade officials of the Security Council known as chusin (chi. shuchen) also concurrently took charge of supervisory posts in the office of the Inspector General and censorial positions. The surveillance and censorial officials frequently acted in

\footnotetext{
${ }^{192}$ For the establishment of the three department-six ministry system, the description of the History of Goryeo is not consistent; the section of 'official bodies' (chi. baiguan) and 'biographies' (chi. shijia) in the Goryeosa wrote that the Tang administration system was introduced by Taejo or Seongjong. But there is little dispute that the record of the 'official bodies' was mistakenly recorded in the early Joseon period. Choi, Jeong-hwan. (2006). Goryeo chogi-ui jeongchi jedowa samseong yukbu-ui seongnipmit byeoncheon ((The Creation and Transformation of the Three Ministries-Six Departments and the Political System in the Early Goryeo Dynasty). Yeoksa hakbo (Korean Historical Review), 192, 67-68.

${ }^{193}$ In the early 1970s, Byeon Tae-seop suggested modification of the three-department system into a joint department in its function and based on his work his opinion has become the favoured interpretation of the early Goryeo political system. But other historians, for example, Choi Jeong-hwan, state that the system is consistent the Tang's three departments which had different roles and operated in a separate realm.

${ }^{194}$ Byeon, Tae-seop (1971). 3-5. Duncan (2000). 43.
} 
concert under the combined name daegan 臺諫 (chi. taijian). In effect, this pattern of concurrent appointments implies the consolidation of the important censorial and surveillance functions under the Bureau of Military. The power, therefore, was concentrated in the inner circle of the top authority body composed of ministers, the jaesin and chusin, and their status as consultants with whom the king sought help on major political issues.

The civil-norm dominant politics of the early period of Goryeo, however, has been regarded ironically to be the cause of its demise. ${ }^{195}$ The dominance of civil officials in the government, even in military affairs, brought about a military coup, and military rule continued for a century until the Mongol invasions of Goryeo in the first quarter of $1200 \mathrm{~s} .{ }^{196}$ The system of checks and balance within government institutions was broken and the military were able to dispose and replace monarchs to suit their political interests. Institutional entities were subordinated to their private residences controlling personnel and state revenue. Exercising their personnel authority, they promoted low ranking literati talented in letters and administration skills into government vacancies as functionaries. ${ }^{197}$ The political crisis of Goryeo over the weakness of the throne did not disappear after military rule ended with the Mongol invasion in 1234.

Added to military and aristocracy, another variation of power landscape of Goryeo was the Yuan court and those Goryeo Koreans who built connections with Yuan factions. Therefore, when there was political turmoil in the Yuan court, this did not fail to have a corresponding influence in Goryeo. The existence of opposing factions in both courts was another factor to explain the instability of the Goryeo monarchy. For example, King Chungseon (忠宣王 r. 1298, 1308-1313), king of Goryeo but also grandson of Kublai Khan, suffered exile and death because of factional strife within the Yuan court. Institutionally, new political activity, chinjo 親朝 (chi. qin chao) and the Goryeo ruler's regular visits to or residence in the Yuan capital, was followed by the establishment of the Yuan Directorate Office, zhengdong

\footnotetext{
${ }^{195}$ Shultz, E. J. (2000). Generals and Scholars: Military Rule in Medieval Korea, trans. by Kim Beom, 29.

${ }^{196}$ Generals from the Choi family could maintain their power from 1170 until the Mongol invasion of Goryeo with monarchs remaining as the symbolic head. Ibid. 276.

197 The Personnel department was staffed largely by functionaries and low-rank civil officials who supported the first military ruler, Choi. Schultz regards this period as one when aristocratic culture blossomed, instead of a dark period of civil culture. Yi U-seong saw these functionaries as the origin of the sadaebu class who would bring about dynastic change. Yi, U-seong. (1964). Goryeogi-ui yi-e daehayeo (A Study of functionaries (chi. $l i$ 吏) during Goryeo period). Yeonksa hakbo, (1991, 81). Another opinion on the origin of the sadaebu class is suggested by Min Hyeon-gu who identified them as the group of civil officials who had been infused with the neo-Confucianism of Zhu Xi around 1350s. 94.
} 
hang zhongshusheng 征東行中書省 in 1280 ensured their supervisory control of Goryeo government.

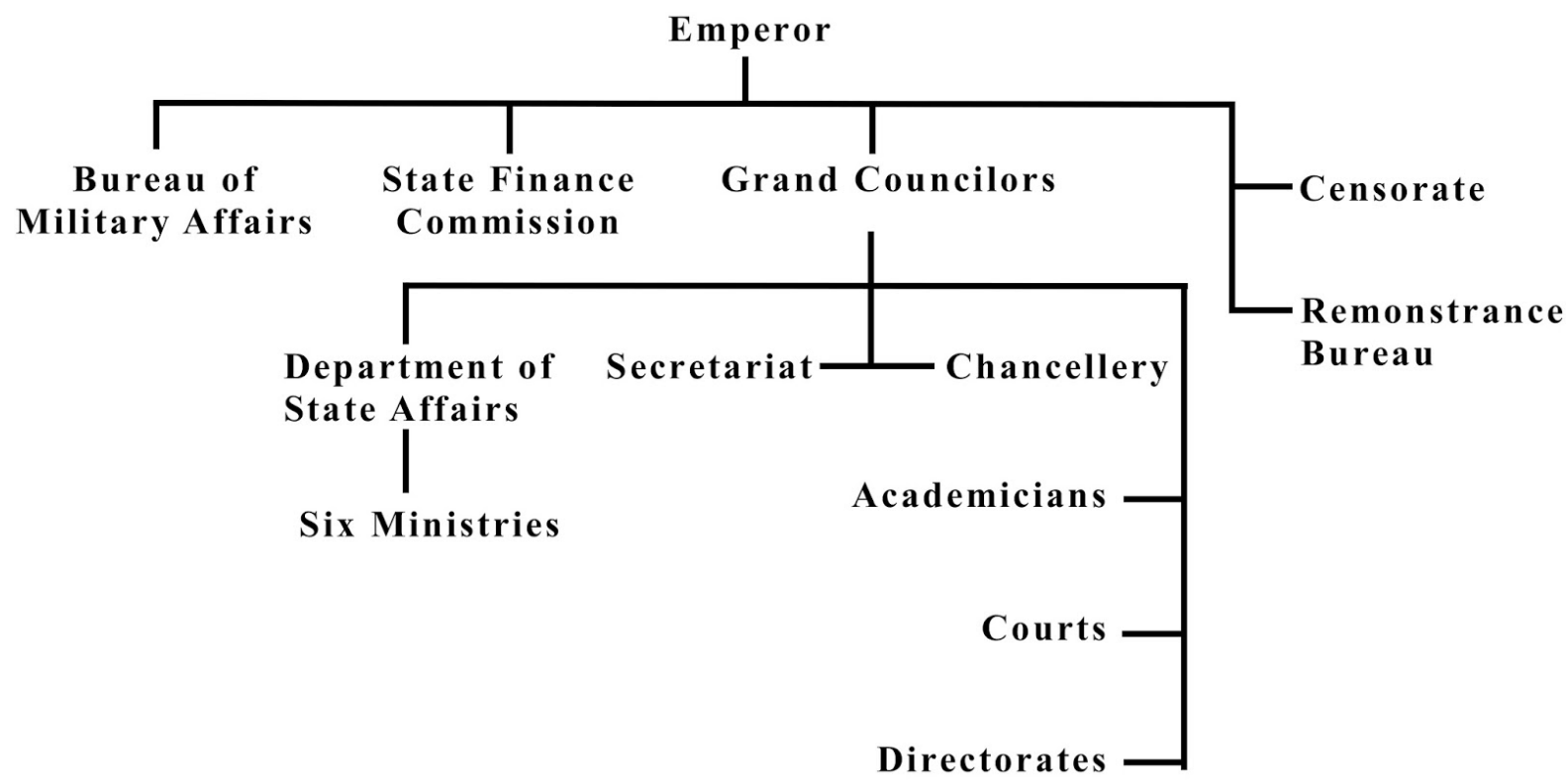

Figure 2. Government structure of Song China (960-1279)

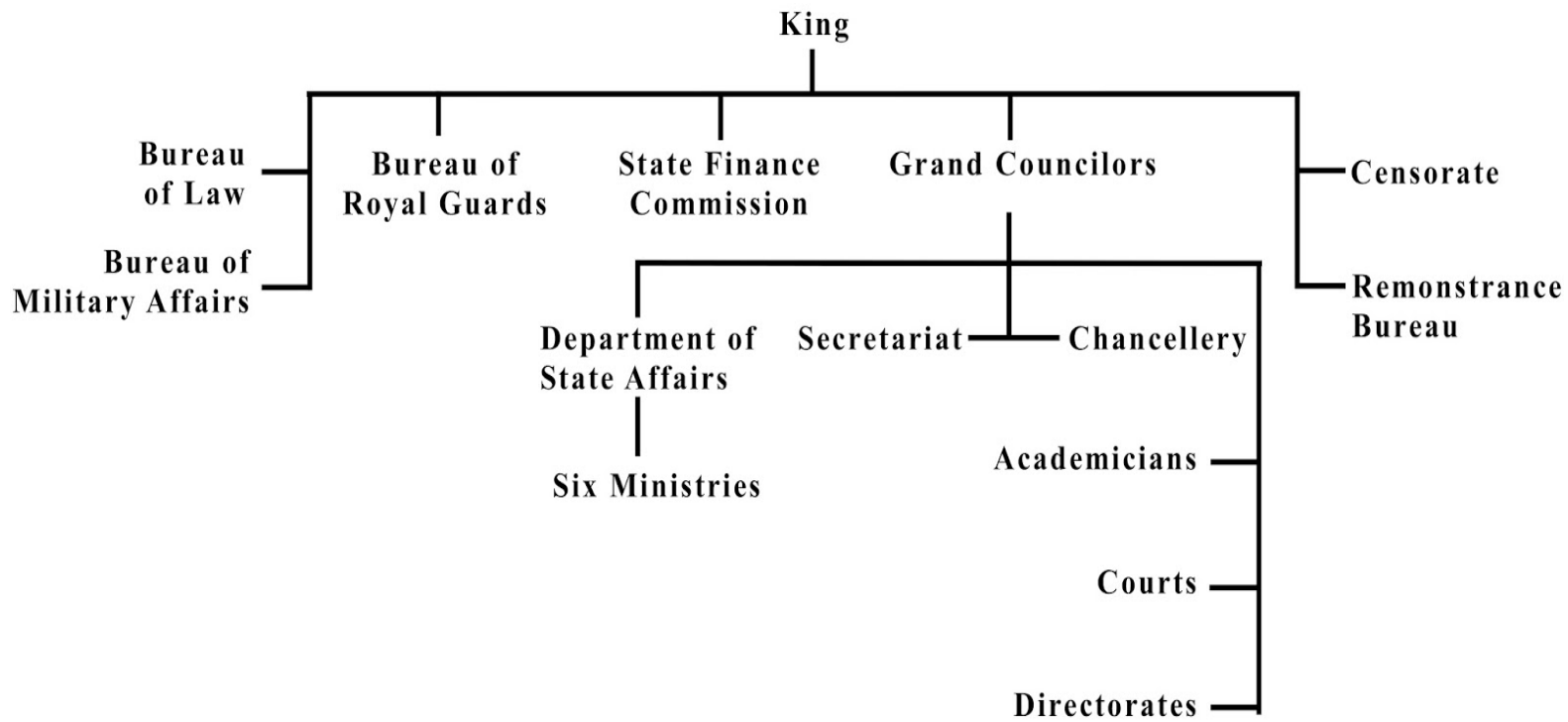

Figure 3. Government structure of Goryeo Korea (918-1392) ${ }^{198}$

\footnotetext{
198 The Bureau of Law, sikmokdogam 式目都監, was new to Goryeo and responsible for arranging government affairs in accordance with Chinese law and rituals; the Bureau of Military Affairs, dogyeong masa 都兵馬使 was originally established as an ad hoc privy council made up of grand councillors, but it expanded its role and power over military and diplomacy matters and even finance after the end of the Yuan's control of Goryeo. Byeon, Tae-seop. (1971).
} 
There was also an influx of foreigners, eunuchs, and royal retainers into Goryeo court politics, the council and the bureaucracy. This was a result of the newly adopted chinjo, or political hostage system sugwi 宿衛, imposed on Goryeo rulers and princes who were made to reside at the Yuan court. Because of prolonged periods of absence of monarchs from the Goryeo capital, it was necessary for a newly-enthroned king had to establish the monarchcentered power structure as soon as he returned. To do so a king had to rely on his supporters who had established an intimate relationship with him in the Yuan palace. However, with the return of the king, the influx of loyal servants into the existing institutions, in particular to the Privy Council, dodang, potentially evoked the animosity of those who had remained. The Yuan also wanted to lessen the influence of the state councillors in the old administration. ${ }^{199}$

King Gongmin's radical policies to regain autonomy from the Yuan were largely possible because the Yuan government began to lose its grip on domestic and international politics in 1350s. The Yuan court had been experiencing factional division between the imperial family and the ruling elite, a malfunctioning administration, natural disasters such as flooding and epidemics, and the growing power of increasing numbers of warlords in Southern China (Farmer 1995). Alerted by the abduction and poisoning of his young nephew king, Chungjeong (1349-1351), followed by his half-brother Chunghye (1315-1344), who suffered a similar fate ordered by the Yuan, who had now put him on the throne, King Gongmin was also mindful that a group of high-ranking Goryeo officials had proposed another candidate to the Yuan emperor to be their next ruler. In such a politically insecure position he returned to Korea with his Mongol queen in the winter of 1351. It was not long before Gongmin found himself confronted with the task of re-establishing the centralization of power, reducing the power of the remaining pro-Yuan families and aristocrats, and creating a power balance among the different cliques in central government. As a mature ruler he was able to drive through three stages of reform during his reign although the issues and formula of centralization changed over this time. In his first five years, King Gongmin followed a course of military expansion which proved to be effective in the centralization of his authority as with early Goryeo rulers. ${ }^{200}$ Through military action against the Yuan, he restored Goryeo territory along the northern

\footnotetext{
${ }^{199}$ Lee, Jong-Hoon. (2015). Wonganseopgi gukjeong yunyeonggwa dopyeonguisasa (Government Operation during Yuan's Intervention and Dopyeongeuisasa). Hanguk sahakbo (The Journal for the Studies of Korean History), 59, 189-226.

${ }^{200}$ Duncan (2000). 13.
} 
border of the Yalu River (see map). In cultural matters he eliminated non-Goryeo traits that had been dominant for a century and identified Gija as the father of the state. It was possible thanks to the support of the civil officials who welcomed the rise of the Ming that was believed to be a revival of Han statecraft based on guzhi.

Then, with the imposition of military control in the 1360s to combat incursions of the Red Turbans across Goryeo's northern border and Japanese pirates along its southern coastline, the Privy Council was dominated by the military and it was they who decided Gongmin's successor after he was assassinated in 1374. Under the Yuan's control there were fifteen changes to state institutions and a proliferation of ad hoc offices. The number of Council members during the reign of King U, successor of Gongmin climbed to over sixty, and the more the membership of the Council increased, the less efficient the decision-making process became. ${ }^{201}$ This was largely because of the way the Council made decisions where all members in agreement did so with their own signature. With the military dominating the membership of the Privy Council, the 1388 coup led by the general Yi Seong-gye has been interpreted as a struggle between the generals in the capital and those civil officials allied with him. When Yi turned his army back from the northern border conflict with the Ming and returned to the capital, the offices they took over were those of the Military, Personnel and Finance. Jeong Dojeon along with Jo Jun became the Right and Left commanders, respectively, in the Bureau of Military Affairs, and concurrently held various titles and offices.

The second cause of institutional difficulties can be attributed to the legal discrepancy resulting from a collision of Yuan punishment law and the existing Goryeo law. Since the peace treaty of 1270 that guaranteed the autonomy of the Goryeo polity, changes occurred in both courts that were involved with their own political interests. Moreover, the compendium of punishments laws, Dayuan tongzhi 大元統制) imposed by the Yuan in the 1320s on Goryeo legal institutions stirred tension among Goryeo law makers. This is revealed in the dialogue of Yi Gok (1298-1351) who informed a Yuan official that he believed that the Yuan's enforced effects in Goryeo Korea would damage the Confucian values of society. As a country that had inherited 'law and culture from the Gija Joseon', it was required to follow Yuan law which had been created according to the traditional Confucian principle of governance. But in practice, as

${ }^{201} G S, 118$, yeoljeon (biographies) 31, jeshin (officials), Jo Jun. Retrieved from kr_118r_0010_0010_0030 $(02 / 05 / 2018)$. 
Yi Gok stated, Yuan authority in Goryeo relied on the Yuan code for civil and military matters, while local offices based their operation on the precedents of previous Goryeo rulers. This resulted in legal inconsistency, with neither being dominant in practice. ${ }^{202}$ This impasse necessitated Goryeo intellectuals to find a compromise in the practice of law, between 'the universal and the local.' In modern Korean literature the influence of the Yuan on Goryeo law and legislation has drawn less attention than that of the Han cultural tradition. This is largely because the effects of the Yuan have been discussed in terms of their nomad (or barbarian) cultural orientation, not in their role as part of Chinese civilization. However, the discovery one of the Yuan's codes, Zhizheng tiaoge, in Korea in 2012, has encouraged the academic community not only in Korea but also in China and Japan, to undertake further research. ${ }^{203}$ Although there are no Chinese records of the Yuan Law of Punishment, Zhizheng tiaoge, it was adopted for civil and criminal matters in 1377 in Goryeo after the end of Yuan control. ${ }^{204}$ Moreover, reference to Yuan legal books did not stop with the collapse of the Goryeo dynasty; instead as major legal sources they were reprinted and consulted in various cases whenever there arose uncertainty or conflict between the two different regulations. ${ }^{205}$

The third reason for the crisis of the late Goryeo and the most critical one was related to the land system. The land reform is it that was blessed most with neo-Confucian ideological derive in social reform that earned reformative Confucians preoccupation after the 1388 coup. As long as social standing of individuals determined in Goryeo society, the land system could be a matter of life and death. In an agrarian society land was the source of legitimacy of power. In such a traditional society in which agriculture is the main industry, land and crops were referred to the 'god of earth and god of crops' sajik 社稷 (chi. sheji), a concept which extended far beyond its geographical containment. Land was the source of political power, division of

\footnotetext{
${ }^{202}$ Kim, In-ho. (1999). Goryeoside wonyul suyonggwa goryeoyului byeonhwa (The Intoduction of the Yuan's Penal Law in Goryeo and the Changes of Goryeo Penal law), Hanguksanon, 33, 60.

${ }^{203} \mathrm{Kim}$, Ho-dong. (2007). Jijeongjogyeokui pyeonchangwa beopjesasang (The Reprint of the Zhizheng tiaoge and the Political Situation of the Late Yuan), Jijeong Jogyeok. Seoul: Humanist.

${ }^{204}$ GS 133, yeoljeon (biographies) 46, the article of Feburary of the third reign of King U. Retrieved from kr_133r_0050_0020_0110(02/05/2018):

${ }^{205}$ Furthermore, the Yuan code was a required subject for candidates of law specialist examinations. Legal handbooks including Lixue zhinan (a guide to clerk knowledge) written in 1301 by Xu Yuanrui and Yixing yilan (an easy reader for deliberating punishments). Yixing yilan was made a reference legal text on the same level as the Ming Code by the Goryeo Ministry of Justice in 1388, and it remained influential during the $15^{\text {th }}$ century. Jerome Bourgon and Pierre-Emmanuel Roux (2016). The choson Law Codes in an East Asian Perspective, 1951.
} 
social status, and its distribution and use determined the type of polity. ${ }^{206}$ This has been cited as a major reason for dynastic change. A recent study noted that 'reform of private land, hyeoksajeon (革私田)' was the phrase most frequently referred to in the memorials to the king in the history of the Goryeo dynasty. ${ }^{207}$ Moreover, the term 'private land' had implications of a societal evil in a neo-Confucian context. ${ }^{208}$ The land system was also deeply rooted in the development of the central bureaucracy. Officiating literati for administrative positions in civil, military and miscellaneous affairs were required to provide an economic basis for their service. Therefore, as soon as the civil service examination initiated the employment of staff not by origin but by merit, economic benefits were given for their service through the Field and Woodland Rank system jeonsigwa 田柴科, instituted in 976. Under this system, government officials were provided tax receipts from land allocated to them by categorizing the grades of the official positions into eighteen degrees. The jeonsigwa system established two major categories of land; state land (gongjeon) and private land (sajeon). The former denoted land for which tax receipts went into the central government treasury, while the latter denoted those belonging to the various classes of persons who provided services to the state. ${ }^{209}$ This was supplemented by salaries nogeup 祿邑 paid in rice on a quarterly basis. ${ }^{210}$ This system was another step toward establishing the central bureaucratic society of the Goryeo dynasty. As the economic base of the ruling class was founded on institutional measures, before long, the status of the, 'two branches (the civil and the military)' yangban was not limited to their profession but extended to their social standing. ${ }^{211}$ In principle, the land distributed to civil servants was to revert to the state for redistribution upon the death of the recipient, although sajeon included inheritable rights which provided for families of deceased high-ranking officials-to collect tax receipts. But as state affairs were fallen into hands of military power and their personal favours, so did great official descent groups take advantage in converting their rank land into private landholdings, leading to the rise of great landed estates.

\footnotetext{
${ }^{206}$ Kim, Sang-yong. (1974). Tojisoyugwonbeop sasang (The Concept of Land Ownership Right). Seoul: Mineumsa: Hung- Chao Tai (1974). Land Reform and Politics. Berkeley: University of California Press.

${ }^{207}$ Shin, Eu-Jae. (2014). A Political Constitution of the Concepts of Sajeon (私田) in the Late Goryeo Dynasty.

The Journal of Korean Medieval History, 40, 299-340.

208 Ibid, 313.

${ }^{209}$ Duncan. (2000). 44.

${ }^{210}$ Ibid. The nature of land system of early Goryeo over ownership or prebend rights has been controversial among researchers. Because of the paucity of documents of the period, modification of the Tang and Song land systems in Korea cannot be examined in any detail.

${ }^{211}$ Kim, Dang-Taik. (2000). Goryeo yangban sahoiwa hanguksaui sidegubun (The Periodization of Korean History in Relation to the Yangban Society of Koryo Dynasty. Yeoksa hakbo (The Korean Historical Review), 142, 67-93.
} 
What, then, was at the core of the legal discrepancy causing administrative malfunctioning in Goryeo? Largely, and more related to the nature of Goryeo administration, state affairs were independently managed by various offices consulting on the precedents compiled in each office and maintaining a degree of autonomy from higher offices. Decentralized administration was also closely allied to budget management to maintain each office position. In other words, the roles and legal enforcement of bureaus, six ministries, suboffices of ministries, and ad hoc organs - temporarily established during Gongmin's and subsequent military campaigns, were so decentralized that abuses of administration tasks undoubtedly occurred. ${ }^{212}$ The legal enforcement by precedents of each office, in fact, was also vulnerable to the influence of powerful families. When prince Gongmin returned to Goryeo from Khanbaliq as an adult, he has shown enthusiasm with reform with support of a group of bureaucrats led by Yi Je-hyeon, announcing two reforms in order to strengthen his authority in politics and finance; dismissal of the chamber of policies, jeongbang 政房, and the establishment of a correction body of land and people, jeonmin byeonjeong dogam 田民辨整都 監. ${ }^{213}$ The former reform was to weaken the power of the council while the latter was to make an accurate land survey and scrutinize the register of population so that land or people illegally taken by powerful aristocrats or officials as their private property could be returned to where they belonged. This land-people reform was reportedly carried out sixteen times during the reign of Goryeo kings before King Gongmin although each time the objectives of the policy differed. The land-people reform was a very effective weapon against politically unfavourable groups or individuals, including the relatives or loyal subjects of a previous ruler, to end their material foundation and strengthen the new royal order. ${ }^{214}$ The problem was that such measures did not lead to a fundamental change of the economic system, instead, but instead increased tensions over state revenue, making aristocratic landholders extend their properties by any means they could use. The crisis in Goryeo administration, therefore, needed to be resolved in Jeong's Code for the succeeding Joseon dynasty by legislation with an ideological direction.

\footnotetext{
${ }^{212}$ Kim, In-ho. (2000). 10.

${ }^{213}$ Shin, Eun-Jae. (2010). 371-400.

${ }^{214}$ Kim, Young-su. (1998). Tojiwa jeongchihak (Land and the Study of Politics), Journal of Korean Political and Diplomatic History, 20, 34.
} 


\section{4-3. Six Law Corpora: Net Ropes of Society}

Before we turn to the origin of the six corpora system it is worthwhile mentioning that there was another composition of a new code, Sinjeongyul 新定律, by Jeong Mong-ju, a compatriot of Do-jeon and who became the top-ranked prime minister during the reign of last Goryeo king, Gongyang. It is known that he consulted existing corpora - Yuan codes, Yuan legal handbooks, and even the Ming Code - from which he composed and presented the Sinjeongyul to the king in 1392. With dethronement of the king and the murder of Jeong Mongju, his code was neither put into practice, nor left any record of its contents in the chronology of the Goryeo dynasty except the title.

In the preface of the Code, Jeong Chong (1358-1397), a minister and Jeong Do-jeon's co-compiler of the Goryeo History, Goryeo guksa 高麗國史, which was the first compilation of the history of Goryeo but is not extant, emphasized that it was the six corpora of laws that had been instituted long ago and on which the rise and fall of a dynasty was dependent. He then attributed the cause of social disorder in the late Goryeo period to its absence. ${ }^{215}$ Jeong's emphasis on such "laws (kanggi 綱紀) that have been lacking during Goryeo and without which a political entity could not function properly," ${ }^{216}$ however, is another reason of leading the researchers of the Code towards narrow perspectives of the Code as legislation. However there are various pieces of evidence of the characteristics of the Code envisioning a political entity of Korea: therefore, it was highly political, rather than legislative. The evidence for this is both the Code's simplicity, containing general principles for each of the corpora, and the concurrent legislative attempts ongoing by Jeong's contemporaries, Jo Jun and Jeong Do-jeon himself. Let us turn finally to examine the articles of the second part of the Code, the six law corpora, by which society was expected to function according to enforced cultural norms in format of law.

First of all, Jeong's Code did not end up printed or distributed for use in enforcement. Moreover, the simplicity of the Code structure and the way of submission to the first king of Joseon draw attention. Regarding Jeong's composition and submission of the Code there

${ }^{215} S B 8: 24 \mathrm{a}-25 \mathrm{~b}$

${ }^{216}$ Deuchler. (1992). The Neo-Confucian Transformation of Korea: A Study of Society and Ideology, 108. 
survived three records; two official records in the Veritable Records of the Joseon Dynasty ${ }^{217}$ and his letter to the king in submitting the Code. ${ }^{218}$ The Veritable Records during the reign of Taejo stated that Jeong Do-jeon was rewarded with a horse, silver, and patterned silk cloth for his work. Jeong's personal record provides more detail, "Taejo ordered the royal secretariat, Han Sang-gyeong, to bring the code that I had been commanded to compose. His Highness was satisfied with it and gave me words of complement." 219 Then, Jeong Do-jeon advised Taejo to keep the document close so that he could read it whenever he desired to remind himself on the principles of governance. His record ends with a description of Yi Seong-gye placing the Code in a golden casket. These records are significant to have a suspicion that Jeong attempted to produce an independent law book for new dynasty. However, it sounds more reasonable that Jeong prioritised legitimization of the Yi Clan dynasty rather than the compilation of legislation.

Another matter remains for evaluating the status of Jeong's Code: was it ever officially recognized, or did it just remain Jeong's personal ideas? There are two opposing viewpoints on this; one that the Code was not part of the legislation of Joseon Korea ${ }^{220}$; it should contextually be regarded as part of a public document; ${ }^{221}$ and the other that although the Code was neither proclaimed, nor printed to be recognized as legislation, it deserves consideration as providing the legal spirit as it became the prototype of later compilation of Joseon laws. ${ }^{222}$ Some historical records of Jeong Do-jeon engaged with the compilation of precedents issued since 1388 led by Jo Jun, another early Joseon lawmaker, have been used in modern literature to characterise the status of the Code. For example, the Jeungbo munheon bigo 增補文獻備考 (Revised and Enlarged Edition of the Comparative Review of Documents, published in 1770 in Korea) states:

In the fourth year of the reign Taejo [Yi Seong-gye, the founder of Joseon] he had commanded

\footnotetext{
${ }^{217} J W S, 2,5: 21 \mathrm{a}$.

218 SB 3:11.

219 SB 3:11a.

${ }^{220}$ Pak, Byeong-ho. (1974). Hanguk beopjesago (A Study of the Legal History of Korea) Seoul: Beopmunsa, 1974.

221 Jung, Geung Sik. (2015). Joseongyeonggukjeogwa joseonchogi beopje jeongbi (Chosunkyeonggukcheon and the Organization of Legal System in the Early Chosun Dynasty. Beophak (Law Studies), 56 (2) 85-116.

222 Jeong, Ho Hoon. (2007). Joseonjeongi beopjeonui jeongbiwa gyeonggukdejeonui seongnip (The Early Joseon Legal Compendium and the Compilation of Gyeongguk Daejeon). Gyeonggje yukjeon and the Establishment of Six Canons system (edited by Yoon Hun-pyo), 47-96. Seoul: Hyean.
} 
Jeong Do-jeon to compile Gyeongje yukjeon 經濟六典 (Six Canons for Governance); and later Ha Ryun [1347-1416] was ordered to submit it [to the court]."223

This extract can be interpreted in two ways; first, Jeong was in every way engaged in the compilation of the Six Canons for Governance in collaboration with Jo Jun; or, Jeong's code and Jo Jun's were confused due to their similarities in the name of the titles. These questions remain, but no matter whether Jeong Do-jeon was also involved in the compilation of Gyeongje yukjeon together with Jo Jun or not, it is certain that urgent task of compendium of laws for administration was in process. Jeong Do-jeon himself was also one of the translators of the Great Ming Code into idu 吏讀 system and the Korean edition of the Ming Code was published same year of the compilation of the Code. ${ }^{224}$

The unusual simplicity of the Code in comparison with other traditional law codes was first noticed by Asami ${ }^{225}$ who analysed the Code conveying the most of the first royal decrees in it. Asami also suggested the present Code as it exists could be simply an outline of general principles, and that the main body of specific regulations was missing. This idea was rejected by Kim Seong-jun who proposed that the Code was projected to present the principles of legislation for the compilation of precedents and cases which was being conducted by Jo Jun. ${ }^{226}$ The work of Jung Geung Sik supports Kim's suggestion, arguing that the thirty-three last sentences of the five canons sections of the Code had no indicator of future tense, and that the Code was therefore the completed version as it stood. ${ }^{227}$ Despite the simplicity of the contents of the second part of the Code, the information in the Six Corpora is sufficient to allow a glimpse of the society that one of the most high-rank ministers of the Joseon dynasty would have liked to shape.

\footnotetext{
${ }^{223}$ Jung, Geung Sik. (2016). 94.

${ }^{224} I d u$ is a writing system of Korean sound with Chinese characters, which is known to have been invented by Seol Chong (655-730) around $8^{\text {th }}$ century. The translation of the Ming Code was therefore for the magistrates and functionaries in local offices for penal matters. Suh, Jong-hak. (2011). The Concept and character of Idu (吏 讀). Journal of Kugyol Studies, 27, 27-56.

${ }^{225}$ Having served as a judge for the high court in Seoul, Asami Rintaro is known to have been involved in the survey of old documents in Korea and was a member of Korea's old books reprinting society. For many years he served as a jurist and conducted research of old documents and books written in classical Chinese. Cited in Kim, In-ho. (2001, 128).

${ }^{226}$ Kim, Seong-jun. (1985). Hanguk jungse beopjesa yeon-gu (A Study of the History of Politics and Legislation of Medieval Period of Korea). Seoul: Iljogak, 371-373: Jung Geung-sik (2015; 94).

${ }^{227}$ Comparison of two codes is taken from Jung's analysis, Jung (2016).
} 
The first article of the Personnel (治典) is the Jesang nyeonpyo 宰相年表, literally meaning of the 'Chronology of Grand Councillors', but instead of providing a list of names of the Grand Councillors throughout recorded history it only states the importance of the role of Grand Councillors. Therefore, it has been taken as evidence for those researchers for whom the Code was a preliminary work for a forthcoming compilation of Jo Jun's Gyeongje yukjeon in 1395. After the preface to the section of Grand Councillors, seven articles follow: the official grades system, a chronology of grand councillors in the history of East Asia, the employment of officials, the employment of functionaries, military officials, monetary and grain management, and honorary titles. In recruiting officials, two methods are stipulated: by recommendation of students good at literature at school, and through the civil service examination. Out of the thirteen articles from the Personnel section of the Yuan Jingshi dadian, eight were adopted. Those omitted were provincial offices, Confucian tutors, hostages, inheritance of titles, and matters of administration.

The second law corpus is Revenue (賦典) which also begins with general principles. Out of twenty-two articles from the Revenue section of Jingshi dadian, nineteen articles were adopted into the Code. The principle of state revenue was confirmed as "not to spend more than what one has" (liang ru wei chu 量入為出), and fair taxation was generally emphasized. The articles in order consisted of land surveying, promotion of agriculture and mulberry tree growing for silk production, setting up of a public grain loan system in case of famine, a public pharmacy, and policies in preparation for nation-wide natural disasters. What is missing in the Code compared with corresponding law corpora of Jingshi dadian are articles concerning paper currency, vinegar, which Jeong must have thought were not relevant for Goryeo society.

The next law corpus, Rites (禮典), comprises twenty-eight articles out of thirty-two from the Yuan code and three articles added dealing with marriage, funerals and house shrines. The articles are as follows: general principles, morning sessions of discussion, ceremonial banquets, land for royal agricultural rituals, royal carriers, music, calendar, royal lectures, ornaments, mourning state and royal rites, ritual manuals for diplomacy, education and civil service examination, public opinion, and establishing Confucian social order. In addition to royal ritual occasions, investiture of noble titles, the articles of education, marriage, funeral and state rites in cases of natural events such as storm, snow, lightning, and rain were also included. 
The corpus on War is jeongjeon (政典) identical to its name in the Zhouli. ${ }^{228}$ In the general principle of the Code, Jeong Do-jeon explained that the reason of taking the character of 政, not byeong 兵 (military), was that raising military power was supposed "to correct 正" the wrongful. Among seventeen articles from 'War' in the Jingshi dadian fifteen were adopted in the Code, these were: the military system, weaponry, training, maintaining weapons, rewards and punishments, garrison land, construction, horse transportation, officials responsible for feeding horses, palace guards, border defence, charity, military land, patrols, and hunting. What was not included dealt with Yuan punitive expeditions, against Goryeo Korea, Japan, Vietnam, and other neighbouring kingdoms, archers, and miscellaneous records of war.

The fifth law corpus is Justice (刑典), an exact copy of the contents of the Great Ming Code with minor changes in the order and names of punishments. Following the introduction on punishments and general principles are articles dealing with: punishment for crimes by officials, crimes committed by civil or military officials, households and corvee services, sacrifices, ceremonial regulations, laws on military affairs-guarding palaces, military administration, guard posts and fords, stables and herds, postal relay stations, robbery and theft, homicide, affrays and battery, cursing, accusations and law suits, accepting illicit goods, committing fornication, miscellaneous offenses, arrests and escapes, constructions and manufactures, and dikes.

The last corpus of laws is Public Works (工典) which comprises eleven articles, half from the same section in the Jingshi dadian: palaces and gardens, government offices, granary, fortification, royal shrines, bridges, weapons, royal ceremonial objects, tents and rugs for royal use, craftsmanship of gold, silver, jade leather, stone masons, paintings and pottery; silk and hemp were not included.

The ideas readers are able to have from reading the six law corpora of Jeong's Code are a general picture of the society that Jeong intended to create and at the same time reflected many of the laws and values of the Goryeo dynasty. Among the corpora, it may be the law of Revenue, the law of Rites and the law of Justice - economy and social order and the punishment to maintain the entire order - that would determine the character of a society, therefore, a short, but significant sketch is useful. For the economy, the Joseon government is 
portrayed as a 'small government' whose monetary policy was suited for a society in which main industrial products come from agriculture. The principle of revenue management borrowed from that of the ancient Confucian classic, $L i$ ji 禮記, as exemplified by a statement of the Hongwu Emperor that explains this economic strategy.

As a household advice, measuring revenue to determine expenditure (liang ru wei chu 量入為出) means not to spend more than what one has. As an ideal of governance, it is connected to the idea of maintaining the public interest and avoiding private gain and is part of a wider principle of managing wealth locally rather than amassing it in the political centre. ${ }^{229}$

For social order, the traditional Confucian social class structure was clarified in the Code. The four categories such of $s a \pm$ (literati), nong 農 (peasants), gong 工 (artisans), sang 商 (merchants) was confirmed so that mobility between classes was not possible. The main economic producers (nong) could also become the defenders (soldiers) of national security under another Zhou principle, byeongnong ilchi 兵農一致. Commoner peasants were to be drafted for training during the non-farming season, which Jeong Do-jeon considered would keep expenditure low for mobilizing and training them. ${ }^{230}$ As long as a portion of land was given to literati ( $s a \pm$ ) who provided service to the king, they were exempted from military service and the tillers of the land remained the most important source of the income of these temporal land owners.

The law of Justice is undoubtedly at the core of the maintenance of society. In international affairs, the fact that the article dealing the Yuan's punitive expedition, zhengfa 征伐 against Goryeo was excluded from the Code can be regarded as an official announcement of the end of the previous Goryeo-Yuan tribute relationship. It also meant that Joseon Korea positioned itself as a vassal country of Ming China which they believed a revival of Han Chinese civil order in the East Asia region.

\footnotetext{
${ }^{229}$ This was the financial management principle typical of Confucian agrarian society, although currency measures were employed as an important medium of economic activity. This is well illustrated by the Ming Emperor; on a summer day in 1390, the Hongwu emperor held a nomination ceremony for the new heads of the six ministries. Addressing the former Minister of Works and new Minister of Revenue, Zhao Mian 趙勉 (jinshi 1385), the emperor laid down his principles for conducting state finance: 'On this day I command you, Mian, to act as Minister of Revenue, to measure revenue in order to determine expenditure so as not to harass the people, and to always keep to public interests and avoid private interests'. See Noa Grass, Revenue as a Measure for Expenditure: Ming State Finance before the Age of Silver. PhD thesis, University of British Columbia, 2015. ${ }^{230} S B 8: 1 \mathrm{~b}$
} 
Even though much of the Code is identical to the Jingshi dadian, there is overall no debate that the society portrayed in the Code is a replica of the idealized Zhou system. ${ }^{231}$ The Zhouli developed not only a source for the formation of government among Goryeo Korean intellectuals but also, thanks to the Song neo-Confucians who had re-examined the conventional values of the authority of the ruler, for an informal institution to expand the ability of ministership within the compromising power formula within the court. They believed that such civil dominant political order had been completed in the institutions during the reigns of King Seongjong and King Munjong, modelled on those of the Tang and Song, a realization of the Zhouli principle. As a political entity, on the other hand, the transformation of Gija Joseon narratives into an ideological drive to the territorial statehood of Goryeo and Joseon as well is demonstrative of the long-standing adherence of the fourteenth century Korean Confucians to the ancient law and culture of the Zhou. The Code of Jeong Do-jeon, therefore, is a showcase of the introduction of the traditional legitimacy of political power into the legality of dual structure, which owed much to the Yuan legal legacy. The policy-making process of proposing, discussion in government and approval from the king remained the existing protocols as was its 'political' ideological basis. Which policies should be prioritised, how the government could work efficiently, and how official positions could be filled with qualified candidates, were decisions that required the same Confucian ideological commitment. ${ }^{232}$ Therefore, Jeong Dojeon's Code is a child of tradition just with a shift of the importance of one of the components that had lasted for thousand years in Confucian statecraft.

\footnotetext{
${ }^{231}$ Han. (1999). 221.

${ }^{232}$ Everett, Michael. (2015). Thomas Cromwell: Power and Politics, New Haven and London: Yale University Press, 10.
} 


\section{CONCLUSION}

Jeong Do-jeon's Code of Governance for the Joseon Dynasty of 1394 was the first document justifying the new dynasty of Joseon in Korea. The Code promoted the restoration of Confucian values of governance that were believed to have been perfected in the legendary era of the sage kings of China. The goal of such state building was realized in the Code by an ideological agenda, weixin (revitalization), according to ancient law and culture, guzhi that had been perfected in what was believed to be the ancient Zhou system, recorded in the Zhouli. The main weakness of modern Korean studies of the Code, such as those by Han Young-woo in regard to the scheme of power separation, is that they are based on the premise that the dynastic change was historically significant in that it established a more differentiated political structure than had existed in the previous Goryeo dynasty, thereby ensuring a balanced power practice for the wellbeing of the people. This attitude fails to consider the dynastic power formula of the late Goryeo dynasty and hinders a full understanding of the society that was represented in Jeong's code of governance.

Jeong's standpoint as codifier was as the inheritor of the long-lasting tradition of Gija Joseon, and he shared the political and cultural orientation of Goryeo elite. This led him to believe that foundation of Joseon should be organized according to the ancient norms of the Zhouli. Specifically, consistency with penal laws from Tang and the government system from Song China was classified in the Code that had already been institutionalized throughout the late $11^{\text {th }}$ and $12^{\text {th }}$ century in Goryeo Korea. More importantly, adaptation of the Yuan Chinese legal format in the Code defines the ideas of institutional continuity and renovation in the emphasis of the strains of Confucian state building programme. Jeong Do-jeon, as the intellect behind the first king of Joseon, incorporated the legal format of royal authority taking precedence of over that of government to document the legitimization of the new throne. The position of prime minister in the Code cannot, therefore, be considered as a mechanism to prevent arbitrary rule by the monarch as Han Young-woo and his supporters have suggested. On the contrary, this study has argued that no matter how much responsibility for state affairs he was given, in the hierarchical order of the codification the role of the prime minister did not change in respect to its subordination to the authority of the throne. 
Another unresolved question is the long-lasting debate over the characteristics of the Code and whether it can be regarded as part of Joseon legislation. Two opinions exist. One focuses in a broad sense on the constitutional arrangement of the Code and argues that the political thought of Jeong Do-jeon largely reflected the components that shaped fourteenth century Korean society. In this sense the Code can be regarded as part of the legal history of Korea. The other opinion is technically a narrow concentration on legality. Although the second part of Jeong's Code comprised six corpora, the absence of legal regulations in practice indicates that it cannot be regarded as a law book. The former is the basis of modern literature on the development of Confucian constitutionalism while the latter relates to the modern legislation process. This study has supported neither of these and has attempted instead to portray Jeong Do-jeon as a Korean Confucian seeking to formulate an institutional foundation for a new dynasty based on traditional hierarchical order according to ritual propriety ( $l i$ 禮), thereby providing a better understanding of him as principally a classicist than as a reforming legislator. Even so, Jeong's renovation by documentation of legitimacy through hierarchical order, into the form of legality, $f a$ (法), should nonetheless be recognised as a significant contribution of a devoted Confucian classicist in formulating the governance code for a new dynasty in late fourteenth century Korea. 


\section{Bibliography}

\section{Primary Sources}

Joseon Wangjo Sillok 朝鮮王朝實錄 (Veritable Records of the Joseon Dynasty, Mt. Taebak Archive edition). Online source of Sillok http://sillok.history.go.kr/main/main.do Goryeosa 高麗史 (History of the Goryeo Dynasty). Online source of Goryeosa is http://db.history.go.kr/KOREA/item/level.do?itemId=kr\&types=r Sambongjip 三峰集 (Collected Works of Sambong, Jeong Do-jeon), Jeong Do-jeon. Haksunje 2016 edition compiled by Jeong Mun-hyeong in 1487.

\section{Secondary Sources}

Brook, Timothy. (2012). The Troubled Empire. Massachusetts: The Belknap Press of Harvard University Press.

Bourgon, J., Roux, PE. (2016). The Choson Law Codes in an East Asian Perspective. The Spirit of Korean Law: Korean Legal History in Context (ed.by Marie Seong-Hak Kim), Leiden: Brill, 19-51.

Bui, Ngoc Son (2012). Confucian Constitutionalism: Classical Foundation. Australian Journal of Legal Philosophy, 37.

Byeon, Tae-seop. (1971). Goryeo-ui jeongchijedosa yeon-gu (A Study of the Institutions of Goryeo), Seoul: Ilsogak.

Chang, Do-u. (2010). Jujagarye-ui suyonggwa bogeupgwajeong (Acceptance and Spreading Process in Jujagarye (朱子家禮: Family Rites of Zhu Xi)- Centering on the Problem about Manuscript copy in Entering to Korea). Gukhakyeongu (Study of Koreanology), 16, 183-206.

Chang, Hao. (1971). Liang Ch'i-ch' Intellectual Transition in China, 1890-1907, Massachusetts: Harvard University Press.

Ch'en, Paul Heng-chao. (1979). Chinese Legal Tradition under the Mongols: The code of 1291, Princeton: Princeton University Press.

Chan, J. (1999). Chinese Law towards an Understanding of Chinese Law, Its Nature and Development. Boson: Kluwer Law International.

Choi Jeong-hwan. (2006). Goryeo chogi-ui jeongchijedowa samseong yukbu-ui seongnipmit byeoncheon (The Creation and Transformation of the Three Ministries-Six 
Departments and the Political System in the Early Goryeo Dynasty). Yeoksa hakbo (Korean Historical Review), 192, 67-106.

Choi, Jong-go. (1980). Jeondojeonui beopsasang (Jeong Do-Jeon's Political Thoughts).

Beopsawa beopsasang (History of Legal System and Thoughts), Seoul: Parkyoungsa.

Choi, Sang-yong. (2003). Changeopgwa suseongui jeongchisasang (Political Thoughts for Founding and Governing a Nation), Seoul: Jipmundang.

(2003). Jeongchiga jeongdojeon yeon-gu (A Study of a Politician, Jeong DoJeon). Asean yeongu (The Journal of Asiatic Studies), 111, 129-155.

(2009). Legalization of Confucianism and Confucian Constitutionalism in the Book of Rite. Korean Political Science Review, 43, Seoul: Korean Political Science Association.

Cho, Won-chin. (2009). Gijajoseon yeon-gu-ui seonggwawa gwaje (Achievements and Tasks in the Study of Kijajoseon). Gojoseon dagunhak (The Journal of Gojoseon \& Dangun Studies), 20, 395-441.

(2010). Yoseojiyeokchulto sangju cheongdonggiwa gijajoseon munje (Shang Zhou Dynasty's Bronzeware and the Kija-Joseon excavated from the Liao-xi Areas). Baeksan hakbo (The Journal of Baeksan), 88, 101-127.

Dardess, J.W. (1994). Shun-ti and the end of Yuan ruler in China. Herbert Franke and Denis Twitchett, eds. The Cambridge History of China, 6, 561-586.

Deuchler, Martina. (1992). The Confucian Transformation of Korea: A Study of Society and Ideology, Cambridge: Harvard University Press.

Do, Hyeon-chul. (1999). Jeongdojeon gyeongjemungamui jujageul wonyonggwa geu uido (The intent of Jeong Do-jeon in quoting of the words of Zhu Xi in Gyeongje mungam) in The Journal of History and Practical Thought Studies, The Historical Society of Yeoksa Silhak, 10-11, 1999; 173-298.

(2000). Wonmyeong gyochegi goryeo sadaebu-ui sojunghwa-uisik (The Koryo Sadaebu's Conciousness of "Little-China" (小中華) During the Period of Dynasty Change from yuan to Ming). Yŏksa Wa Hyŏnsil: Quarterly Review of Korean History, 37, 119.

(2005). Goryeomal yunsojongui hyeonsil insikgwa jeongchihwaldong (Yun So-jong's perspective of and involvement in politics in the late Goryeo). Dongbanghakji (Journal of Yunsei institute of Korean Studies). 1-35. 
(2012). Sambongjipgwa gwongeunui yeokhal (Characteristics of Sambong-jip and the Role of Gweon Geun). Minjok munhwa (the Journal of Korean Classics), 40, 139-169.

Duncan, John. (2010). The Origins of the Choson Dynasty, Washington: University of Washington Press.

Gwen, Eun Ju. (2014). Goguryeoyumin goheumdeok, gowonmang buja myojimyeong geomto (Study of the Epitaphs of Go Heum-deok (高欽德) and Go Won-mang (高遠 望), the displaced of Goguryeo (高句麗)), Daegu sahak (History Journal of Daegu University), 43-77.

Farmer, Edward. (1995). Zhu Yuanzhang and Early Ming Legislation-The Reordering of Chinese Society following the Era of Mongol Rule. Leiden: Brill.

Hahm, Chai-hark. (2000) Confucian Constitutionalism, Harvard Law School J.S.D. dissertation.

(2009). Ritual and Constitutionalism: disputing the Ruler's Legitimacy in a Confucian Polity. The American Journal of Comparative Law, 57, 135-203

Han, Young-woo. (1983). Goryeowa joseongi-ui gija insik (Understanding of Jī Zi in Goryeo and early Joseon Korea). Seoul: Jisiksaneopsa.

(1983). Jeongdojeon sasangui yeon-gu (A Study of the Thoughts of Jeong Dojeon). Seoul: Seoul National University Press.

(1989). Joseonui Sahoisasang yeon-gu (A Social Study of the Early Joseon Dynasty). Seoul: Jisiksaneopsa.

(1991). Joseonui sahoigyeongje yeon-gu (A Study of Society and Economy of the Early Joseon Dynasty). Seoul: Eulyumunwhasa.

(1999). Wangjo-ui seolgyeja jeongdojeon (Dynastic Architect; Jeong Do-jeon), Seoul: Jisiksaneopsa.

Heo, Heung-sik. (1981). Kimji-ui seonsujip, jugwanyugikgwa geu gachi (The significance of the collection of poetry composed by Kim Ji and Jugwan yugik). Kyujanggak, $4,33-47$.

Huh, Tae-Yong. (2015). Joseonwangjo-ui geongukgwa gukho munje (The Foundation of Joseon dynasty and Problem of Naming). Hanguksa hakbo (The Journal for the Studies of Korean History), 61, 145-172.

Il Yeon. (1281). Samguk Yusa: Legends and History of the Three Kingdoms of Ancient Korea, trans. by Tae-Hung Ha and Grafton K. Mintz. Yonsei University Press, 1972. 
Jeong, Ho Hoon. (2007). Joseonjeongi beopjeonui jeongbiwa 'gyeonggukdejeon'ui seongnip (The Early Joseon Legal Compendium and the Compilation of Gyeongguk Daejeon). Gyeonggje yukjeon and the Establishment of Six Canons system (edited by Yoon Hun-pyo), 47-96. Seoul: Hyean.

Jiang, Yonglin. (2011). The Mandate of Heaven and the Great Ming Code. Washington: University of Washington Press.

(2012). The Great Ming Code: Da Ming Lu. Washington: University of Washington Press.

Jo, Won. (2017a). Wonhugi beopje-e natanan yukjeonjedowa geu yeonghyang (The Six canons system of the Yuan law books and its influence -the six canons system of Jingshi dadian). Collected Papers of Seminar of the History of East Asia, 219-233.

(2017b). The Compiling of the Ching-shih ta-tien of the Late Yuan and the Six Code Construction. Doyangsahak yeongu (Journal of Asian Historical Studies), 141.

Jung, Geung-Sik. (2009). Joseonjeongi jungguk beopseo-ui suyonggwa hwalyong (A Study on Use and Imports of Chinese Legal Books in the Early Chosun Dynasty). Beophak (Seoul Law Journal), 50 (4). 35-80.

(2015). Joseongyeonggjukjeongwa Joseonchogi beopjejeongbi (Chosunkyeongkukcheon and the Organization of Legal System in the Early Chosun Dynasty). Beophak (Seoul Law Journal), 56 (2). 85-116.

Kim, Gwang-cheol. (1991). Goryeohugi sejokcheung yeon-gu (A Study of Hereditary Privileged Class of the late Goryeo). Pusan: Dong-A University Press.

Kim, Gyeong-nok. (2011). Yeomal seoncho hongmuje-ui goryeo, Joseon insikgwa oigyo gwangye (Relation between the Ming of Korea during the late Goryeo and early Joseon), Myeongcheongsa yeongu: The Journal of Ming-Qing Historical Studies, 35, 1-33.

Kim, Hak Yong. (2015). Network giban joseonwangjo geongukgwajeong bunseok (Analysis of Foundation Procedure for the Chosun Dynasty based on Network). Journal of the Korea Contents Association, 582-591. 
Kim, Ho-dong. (2007). Jijeongjogyeok (至正條格) ui pyeonchangwa beopjesasang eu-eu (The

Reprint of the Zhizheng tiaoge and the Political Situation of the Late Yuan), Jijeong Jogyeok, Seoul: Humanist.

Kim, In-ho and Yun, Hun Pyo. (2007). Gyeongjeyukjeongwa yukjeoncheje-ui seongnip (The Formation of the Six Code of Administration), Seoul: Hyean.

Kim, In-ho, (1999). Goryeo-ui wonyul suyonggwa goryeoyului byeonhwa (The Introduction of the Yuan's Penal Law in Goryeo and the Changes of Goryeo Penal law), Hanguksanon 33, 41-81.

(2001). Kimji-ui jugwanyugik yeon-gu (A Study of Kim Ji ( 金祉)'s Jukwanyukik (周官六翼)) Yoksawa Hyonsil: Quarterly Review of Korean History, 40, 128-162.

(2002). Yeomalseoncho yukjeon cheje-ui seongnipgwa jeonge (The Establishment and Development of the Six Codes System in the Late Koryo and Early Choson Dynasty). Dongbang hakji, 118, 1-39

(2016). Goryeohugi yijehyeonui jungguk muningwaui gyoryuwa mangwondang (A Study for Mangundang and Lee Jaehyun). Yeoksawa hyeonsil (The Journal of History and Practical Thought Studies), 61, 215-242.

Kim, Nan-ok. (2007). Yeomakseoncho jeongchi byeondonggwa betajeok gamunuisikjeongdojeoneul jungsimeuro (The Political Changes and the Family Consciousness during the Transition from Goryeo Dynasty to Joseon DynastyFocused on the Case of Jeong Do-jeon). Hanguk sahakbo (Journal for the Studies of Korean History), 27, 243-274.

Kim, Nak-jin. (2017). Goryeo gwangjongui siwigun jeungganggwa gunjegepyeon (Strengthening the Siwigun (the Royal Guard) and Reforming the Military Organization during the Gwangjong Reign of the Goryeo Dynasty). Daegu sahak (History Journal of Great Confucius), 127, 117-156.

Kim, Pusik. (1145). The Koguryo Annals of the Samguk Sagi. Trans. by Edward J. Shultz, Seongnam: The Academy of Korean Studies Press in 2011.

Kim, Sang-yong. (1974). Toji soyugwonbeop sasang (The Concept of Land Ownership Right).

Seoul: Mineumsa.

Kim, Seok-geun. (1999). Hunyosipjo (訓要十條) wa simuyisippaljo (時務二十八條) (A Sketch of Political Thoughts of the Early Goryeo Dynasty). The Journal of Asiatic Studies 6, 337-369. 
Kim, Seong-jun. (1985). Hanguk jungse beopjesa yeon-gu (A Study of the History of Politics and Legislation of Medieval Period of Korea). Seoul: Iljogak

Kim, Sung-kyu. (2014). Goryeo woigyo-e-seo euryeowa gukwangeu jase (Ritual ceremonies, as well as the King's posture, reflecting Goryeo dynasty's diplomacy). Yoksawa hyonsil (Quarterly Review of Korean History). 94, 363-394.

Kim, Sung Moon. (2011). Confucian Constitutionalism: Mencius and Xunzi on Virtue, Ritual, and Royal Transmission. The Review of Politics, 73.

Kim, Tang-taek. or Kim Dang-taik (1986). Goryeo muinjeonggwon yeon-gu (Studies on the Goryeo military government). Seoul: Saemunsa.

(1997). Goryeo uwangwonnyeon wongwa-ui woigyogwangyereul duleossan jeongchiseryeokganui galdeung (Factional Tension over deplomatic relation with the Yuan in the first reign of King U). Jindan hakbo 83, 21-41.

(1998). Goryeo uwangde yiseonggyeowa jeongmongju, jeongdojeonui jeongchijeok gyeolhap (The Political Coalition of Yi Song-gye, Chong Mongju and Chong To-jon in Koryo King U's reign). Yeoksa hakbo (Korean Historical Review), 158, 31-62.

(2000). Goryeo yangbansahoiwa hanguksaui sidegubun (The Periodization of Korean History in Relation to the Yangban Society of Koryo Dynasty. Yeoksa hakbo (The Korean Historical Review), 142, 67-93.

Kim, Yong-Oak. (2004). Sambong jeongdojeonui geonguk cheolhak (Philosophy of National Building of Sambong Jeong Dojeon). Seoul: Tongnamu.

Kim, Yeong-su. (1998). Tojiwa jeongchihak (Land and the Study of Politics). Journal of Korean Political and Diplomatic History, 20, 33-75.

Lee, Jeong-Hoon. (2015). Wonganseopgi choban chinjowa gamguk (Chinjo (親朝) and Gamguk (監國) during the early Yuan Intervention period). Hanguksa yeongu (The Journal of Korean History), 171, 101-132.

(2015b). Wonganseopgi gukjeong yunyeonggwa dopyeonguisasa (Government Operation during Yuan's Intervention and Dopyeongeuisasa. Hanguk sahakbo (The Journal for the Studies of Korean History), 59, 189-226.

Lee, Jung-ran (2005). Jeonghidogam hwaldongeseo deureonan gasokui ge-in-gwa geu-ui hengdongbangsik (Individual and Clan Behavior as Seen through the Activities of the Chongch'i Tokam), The Journal for the Studies of Korean History, 21, 297-331. 
Lee, Kang Hahn. (2010). 1325 gijasa jesajege (箕子祠 祭祀 再開) ui begyeongmit eumi (The Nature and Meaning of the Gija Service Resumption in 1325). Han'guk Munhwa (Korean Culture), 50, 3-26.

Lee, You-pyo. (2017). Seoju (西周) chogi gija (箕子) ui joseon (朝鮮) chekbong (冊封) ganeungseong geomto: jehu (諸侯) chekbong yangsanguel jungsimeuro (Reconsidering "the Theory of Kija 's Migration to Joseon" in Early Western Zhou: Focusing on Kija`s enfeoffment by King Wu). Inmunhak yeongu (The Journal of Humanities), 65-97.

Liu, James T. C. (1973). How did a Neo-Confucian school become the state orthodoxy? Philosophy East and West, 23(4). Hawaii: University of Hawaii Press.

Ma, Chong-rak. (2000). Won ganseopgi (元干涉期) ikje yijehyeon ( 益齊 李齊賢) ui yuhaksasang (儒學思想) (The Confucianism of Ik-Che Yi Je-hyun in the period of Yuan interference). Hanguk jungsesa yeongu (The Journa of Korean Medieval History), 71-116.

(2005). Goryeoside (高麗時代) yuhaksa (儒呚史) ui chu-i-wa geseong (Rereading Confucian thoughts in the Goryeo Dynasty). Hanguk jungsesa yeongu (The Journal of Korean Medieval History), 18, 5-42.

Min, Hyeon-gu. (1968). Sindonui jipgwongwa geu jeongchijeok seonggyeok (Shindon's Power and its Political Implication), Yeonksa hakbo, 38-40.

(1998). Jeongchigaroseo-ui gongminwang jewi jeonbangi-ui hengjeoke bo-ineun gyeohyeok gunjuroseo-ui myeonmo (Gongmin as a Politician: Personality as Reform Ruler in his early Reign). Asea yeongu (The Journal of Asiatic Studies), 41 (2), 271-296.

Moon, Cheol-young. (2014). Ingan jeongdojeon: sunsu iseongeseo ye-eonjajeok sangsangnyeokeuro-ui yeojeong (The Man Jeong Do-jeon: A Journey from Pure Reason to the imagination of a Prophet). Seoul: Semunsa.

Noh, Tae-don. (2000). Wiman joseonui jeongchi gujo (The Political Structure of the Wiman Joseon), in the Dangungwa Gojoseonsa (Dangun and the History of the Old Joseon). Seoul: Sagyeojeol.

North, D.C. (1999). Institutions, Institutional Change and Economic Performance, Cambridge: Cambridge University Press.

Oh, Gilsun, (2010). Wongyeongsedejeonjirido-e-naoneun jimyeongui josawa 'honil gangniyeokdegukdojido' seoyeok jimyeonggwa-ui bigyo (A Study on the Place 
Names of the WonKyungsedaijunJirido and the Comparison with Westside of the HonilGangiYeokdaeGukdoJido). Hanguk Gojido yeongu (Journal of Old Maps), 2 (2). 83-105.

Oh, Hyun-Su. (2016). Gijajeongseung (箕子傳承) ui hyeongseong gwajeong yeon-gu (A Study on the Forming Process of the Kija's Legend). Hanguk sahakbo (The Journal for the Studies of Korean History), 65, 51-87.

Ok, Yong-jung. (2014). Joseon gyeonggukjeonui ganhenggwa sejihakjeok yeon-gu (The Publication of the Governance Code of the Joseon and its Bibliographical Evaluation). Sambong Jeongdojeongwa Joseongyeonggukjeon (Sambong Jeong Do-jeon and the Governance Code of the Joseon), Suwon: Museum of Hwaseong.

Oh, Yong-seob. (2011). Sambongjipui ganhenggwa pyeonseong (A Study of the Contents and Publication of Sambongjib). Seojihakyeongu (Study of Bibliography). 229-253. Palais, James. (1980). Han Yŏng-u's Studies of Early Chosŏn Intellectual History. The Journal of Korean Studies, 2, 199-224.

(1984) Confucianism and the Aristocratic/Bureaucratic Balance in Korea. Harvard Journal of Asiatic Studies, 44 (2), 427-468.

(1995). A Search for Korean Uniqueness. Harvard Journal of Asiatic Studies, 55 (2), 409-425.

(2015). Confucian Statecraft and Korean Institutions: Yu Hyongwon and the Late Chosun dynasty.

Pankaj, Mishra. (2012). From ruins from Empire, London: Allen Lane, Penguin Books.

Pak, Byeong-ho. (1974). Hanguk beopsasago (A Study of the Legal History of Korea), Seoul: Beopmunsa.

Pak, Jae-u. (2012). Goryeojeongi-ui jeongchijedo-ui wunyeonggwa dangsongje (The Administration and the introduction of Tang and Song system to Goryeo), Yeongsawa hyeonsil, 86, 15-32.

Park, Cheol-ju. (2006). Demyeongyul jikhae (大明律直解) ui gugeohakjeok yeon-gu (A Study of Korean Linguistic Understanding of Da Ming Lui). Seoul: Iljisa.

Park, Dae-Jae, (2016). Gijajoseon (箕子朝鮮) gwa sojunghwa ( 小中華) (Kija-Chosŏn and Little China). Hanguk sahakbo (The Journal for the Studies of Korean History), $7-49$. 
Park, Hong-Gab. (2008). Hyeoryeongwa gamune euhan deungyong, muneumjedo (Muneum (門蔭), the Appointment by the Lineage and Birth). Oneului Doyangsasang (Today's East-Asian Philosophy), 18, 101-115.

Park, Hong-gyu, and Song Jae-hyeok. (2012). Yugyojeok hyeonjeongju-ui jegeomtojoseonchogi wanggwonui jeongsanghwawa heonjangju-ui (憲章主義) (Review on Confucian Constitutionalism: The Normalization of Royal Authority and 'the Principle of Heon-Zhang (憲章主義)' in the Early Joseon Dynasty Period). Asean yeongu (The Journal of Asiatic Studies), 149. 117-148.

Park, Won-Ho. (2005). Goryeowa Juwongjangui cheot gyoseobe gwanhan sogo (A short note on the first contact between Koryo (高麗) and Zhu Yuanzhang (朱元璋)). Dongbuga Yeoksa Nonchong (Journal of Studies of North East Asia), 3, 189222.

Park, Yong-un. (or Park, Yong-woon). (2004). Gukho goguryeo, goryeo-eo dehan ilgochal (On the Dynastic Names of Koryo 高麗 and Koguryo 高句麗). Dongbuga Yeoksa Nonchong (Journal of Stduies of North East Asia), 1, 29-49.

Peake, Cyrus H. (1937). Recent Studies on Chinese Law, Political Science Quarterly, 52, 117138.

Qing, Jiang. (2013). A Confucian constitutional order: how China's ancient past can shape its political future, edited by Daniel A. Bell and Ruiping Fan; translated by Edmund Ryden, Cambridge: Cambridge University Press.

Robinson, David. (2009). Empire's Twilight: Northeast Asia under the Mongols, Massachusetts: Harvard University Asia Center.

(2017), Rethinking the Late Koryo in an International Context. Korean Studies, $41,75-98$

Shin, Eun-Jae. (2006). Wonjong, chungyeolwangde jeonminbyeonjeong sa-eopui seonggyeok (Characteristics of Jeonmin byeonjung project in the period of Kings Wongjong to Chungryeol). Hanguk jungsesa yeongu (The Journal of Korean Medieval History), 21, 73-110.

(2010). Gongminwang jeukwicho jeonggukui donghyanggwa jeonminbyeonjeong (The Political Development in Early Period of King Gongmin (恭怨王)'s Reign and Jeongminbyeonjung (田民辨正) Project). Hanguk jungsesa yeongu (The Journal of Korean Medieval History), 29, 371400. 
(2014). Goryeomal sajeon damnonui jeongchijeok guseong (A Political Constitution of the Concepts of Sajeon (私田) in the Late Goryeo Dynasty). Hanguk jungsesa yeongu (The Journal of Korean Medieval History), 40, 299340.

Shin, Yong-ha. (2013). Gijajeoseonseol (箕子朝鮮說) ui sahoihakjeok geomjeunggwa beomgeum paljo (犯禁 8 條) ui silche (Sociological Scrutiny of Gija Joseon and the Fact about the Code of Eight Prohibitions). Gojoseondangukhak (The Journal of Gojiseon \& Dangun Studies), 29, 231-312.

Shultz, Edwards. (1979). Twelfth-Century Koryŏ Politics: The Rise of Han Anin and His Partisans. The Journal of Korean Studies, 6, 3-38.

(1979). Military Revolt in Koryŏ: The 1170 Coup d'État. Korean Studies, 3, 1948.

(2000). Warriors and Scholars: Military Rule in Medieval Korea, Honolulu: University of Hawaii Press.

(2003). Courtiers and Warriors: A Search for Equilibrium in Koryo Society, Kyoto: Kokusai Nihon Bunka Kenkyu Sentaa, 399-417.

Son, BN. (2012). Confucian Constitutionalism: Classical Foundations, Australian Journal of Legal Philosophy, 37, 61-98.

Song, Jae-Hyeok. (2016). Jeongdojeonui gunjuron-gyeongjemungambyeoljipeul jungsimeuro (A Study of the Confucian Kingship Theory of Jeong Do-jeon-focused on Kyeongjemungambyeoljip). Jeongchi sasang yeongu (The Korean Review of Political Thought), 22 (2), 75-98.

Song, Jaeyoon. (2009). The Zhou Li <周禮> and Constitutionalism: A Southern Song Political Theory. Journal of Chinese Philosophy, 36, 424-438.

Wood, T. Alan. (1995). Limits to Autocracy: From Sung Neo-Confucianism to a Doctrine of Political Rights, Honolulu: University of Hawaii Press.

Yeon, Jeong-yeol. (1997). Hanguk beopjeonsa (A History of Legal Books in Korea). Seoul: Hakmunsa.

Yi, Geun-myeong. (2010). Songwonside-ui goryeosa jaryo 1 (Collected Resources of the Song and Yuan related with Goryeo). Seoul: Sinseowon.

Yu, Ho-seok. (1993). Gwageojedo yeon-gu (A Study of Civil Service Examination). PhD dissertation. Jeonju: Jeonbuk University. 
(2010). Goryeogwageojedo-ui seongnip (The Institutionalization of the Civil Service Examination of Goryeo Korea). Hanguksa simin gangjwa (Lecture of Korean History) Seoul: Iljogak. 19-39.

Yi, Ik-ju. Or Lee Ik-joo (1995). Gongminwangde gehyeokui chu-iwa sinheungyusinui seongjang (Reformation of King Gongmin and Rise of Confucian Officials). Yeoksawa Hyonsil (The Journal of History and Practical Thought Studies), 15, $22-54$.

(2008). A Study of Lee Saek's political status in late Koryo. Yoksa wa hyonsil: Quarterly Review of Korean History, 155-187.

Yi, Seong-mu. (1994). Hangukui gwageojedo (Civil Service Examination of Korea) Seoul: Jipmundang.

Yi, Won-myeong. (2000). Yeomalseoncho (麗末鮮初) seongnihak (性理學) ihegwajeong yeon-gu (A Study of the neo-Confucianism in the Late Goryeo and the Early Joseon). Guksagwan nonchong (Journal of Korean Studies), 92, 257-286.

Yú, Ying Shih. (2015). Trans. in Korean language as Juja-ui yeoksasegye (History Understood by Zhu Xi), Seoul: Geulhangari.

Zhang, J. (2014). The Tradition and Modern Transition of Chinese law, Berlin: Springer. 